\title{
Mixing Business with Politics? The Role and Influence of the Australia New Zealand Leadership Forum
}

\author{
By
}

Simon Le Quesne

A thesis submitted to the Victoria University of Wellington in fulfilment of the requirements for the degree of Master of Arts in International Relations.

School of History, Philosophy, Political Science and International Relations 2011. 



\section{Table of Contents}

Abstract

Acknowledgements

Abbreviations

Introduction

Chapter One: Conceptualising the Australia New Zealand Leadership Forum

Chapter Three: The Form and Modalities of the Australia New Zealand Leadership Forum

Chapter Four: The Australia New Zealand Leadership Forum and trans-Tasman Relations (2004 - 2010)

Chapter Five: Conclusion. The Role and Influence of the Australia New Zealand Leadership Forum

Figure:

ANZLF Participation by Group 2004-2009 


\begin{abstract}
Since 2004, the Australia New Zealand Leadership Forum (ANZLF), an annual bilateral business-led Forum, has facilitated the engagement of high level state and non-state Australian and New Zealand actors in debate, unofficial dialogue, networking, information and idea exchange. Yet very little is known about the event, who participates and what the ANZLF produces. Drawing on extensive interviews with key participants and organisations, this thesis examines the Forum's genesis, its form and modalities, and the substance of the meetings. While the literature on "tracktwo" diplomacy and regional integration often exaggerates the importance of business and other non-official actors in the process, evidence from the ANZLF case suggests that these participants merely promote, but do not transform trans-Tasman economic integration policy. Rather, the ANZLF has served as a tool for governments to expand their capabilities and to draw on alternative resources. The ANZLF is an example of unofficial diplomacy helping governments to build strategic relationships with a variety of non-governmental actors to advance specific objectives. From a New Zealand perspective, the thesis argues the Leadership Forum has been beneficial in building relationships, networks and trust as the country engages in asymmetrical integration with Australia.
\end{abstract}




\section{Acknowledgements}

First and foremost, I would like to acknowledge and thank my partner Kimberley LorneMcDougall Gustavsson for her encouragement and support. Tack för ditt tålamod och förståelse Kim. I am very fortunate to have a supportive supervisor, and I thank Dr David Capie for his patience and input. David's enthusiasm for this project was outstanding and assisted me in receiving the support of the Herbert Sutcliffe Master by Thesis Scholarship. I owe special thanks to those that continue to support Mr Sutcliffe's legacy. I am also grateful to the faculty for a research grant which enabled me to travel to Australia to conduct research.

Importantly, I would like to thank all those that took time out of their busy schedules and agreed to be interviewed - your input has been very much appreciated and highly valued. Appreciation also goes out to the New Zealand Ministry of Foreign Affairs and Trade who were kind enough to provide me with the information I requested. Additionally, I am extremely indebted to Edwin Boshier for his comments and assistance, and I thank Tony Wilson for his comments on a draft. I would also like to thank my parents, Anne and Peter Le Quesne, and Kimberley's family, Eva and Mats Gustavsson, for their love and support while I undertook this task.

This thesis was written as my son Tias was born. I dedicate this thesis to Tias Gustavsson-Le Quesne - may you know a trans-Tasman world that others have not seen before. 


\section{Abbreviations}

\begin{tabular}{|c|c|}
\hline AALD & - Australian American Leadership Dialogue \\
\hline ANZCCT & - Australia New Zealand Consultative Committee on Trade \\
\hline ANZBC & - Australia New Zealand Business Council \\
\hline ANZF & - Australia New Zealand Foundation \\
\hline ANZLF & - Australia New Zealand Leadership Forum \\
\hline ANZUS & - Australia New Zealand United States Security Treaty \\
\hline ASEAN & - Association of South East Asian Nations \\
\hline CAFCA & - Campaign Against Foreign Control of Aotearoa \\
\hline CER & $\begin{array}{l}\text { - Australia New Zealand Closer Economic Relations Trade Agreement (also } \\
\text { known as ANZCERTA) }\end{array}$ \\
\hline CTU & - (New Zealand) Council of Trade Unions \\
\hline DFAT & - Australian Department of Foreign Affairs and Trade \\
\hline $\mathrm{IR}$ & - International Relations \\
\hline MFAT & - New Zealand Ministry of Foreign Affairs and Trade \\
\hline NAFTA & - New Zealand Australia Free Trade Agreement \\
\hline SEM & - Single Economic Market \\
\hline TTBC & - Trans Tasman Business Circle \\
\hline TTMRA & - Trans Tasman Mutual Recognition Arrangement \\
\hline TTOIG & -Trans Tasman Outcomes Implementation Group \\
\hline TTTPA & $\begin{array}{l}\text { - Trans Tasman Therapeutics Products Authority (also known as the } \\
\text { Australia New Zealand Therapeutics Products Agency) }\end{array}$ \\
\hline
\end{tabular}


"Foreign Policy is what you do; diplomacy is how you do it". Lord Gore Booth. ${ }^{1}$

\section{Introduction}

This thesis sets out to examine the role of the Australia New Zealand Leadership Forum $(\mathrm{ANZLF})^{2}$ in the broader context of the trans-Tasman bilateral relationship. In the years 2004 to 2009, this annual, two-day, business-led and closed-door forum has facilitated the engagement of public and private actors at an elite level, namely politicians, officials, business leaders, academics, unionists and political commentators, to discuss and debate key issues affecting the Australia-New Zealand relationship. The Forum has been a key advocate for the development of the single economic market (SEM) concept, advancing a common border, and promoting greater cooperation in third markets. Importantly, the ANZLF has been useful in building a supportive non-governmental constituency for greater economic and institutional integration between Australia and New Zealand, and advancing New Zealand diplomatic objectives.

Australia and New Zealand are competitors operating in global markets. The governments of both countries are, naturally enough, therefore aware of the need to pursue national interests. Having signed nearly one hundred bilateral treaties, the two countries are also aware of the importance of collaboration to attract global capital into the region. However, facilitating and promoting cooperation to increase the joint competitiveness of both countries' economies through economic integration has remained at times a difficult and drawn-out process on the governmental agenda. As relatively small players in a large and challenging global arena, business support is becoming increasingly crucial to get cooperative strategies off the ground. Therefore, the importance of developing government to government connections to advance joint economic interests and integrative processes is also informed by a close and strategic relationship at the government to business level. ${ }^{3}$ The ANZLF facilitates this trans-Tasman government-business link.

As a relatively new bilateral channel the overall diplomatic aim of the Leadership Forum is to foster and strengthen the relationship at a number of levels through non-official debate and dialogue, through high-level networking, and through information

\footnotetext{
1 Gore-Booth, Lord Paul. "Historic Skills and New Tasks: The Diplomatic Service in the Seventies". Royal Institute of International Affairs. Vol. 46. No. 4. 1970, p. 699.

2 This thesis refers to the Australia New Zealand Leadership Forum as the ANZLF, the Forum, or the Leadership Forum.

3 Crean, Simon. "Australia New Zealand Leadership Forum". Ministerial Statement to the House. 16 June 2008.
} 
and idea exchange in matters of mutual and strategic importance. The Forum's stated role is to "interact with government and with broader business and union interests and the community, to help progress complex policy issues", ${ }^{4}$ with an objective to pursue the free trade of goods and services, capital, knowledge and people. ${ }^{5}$ The precise purpose of the Forum and the extent to which the broad objectives would translate to firm policy change has been, however, a matter of some confusion.

Three broad assumptions from the literature on Australian-New Zealand relations, the ANZLF and international relations are challenged in this thesis. The first is the oft-made claim that trans-Tasman interests are diverging. ${ }^{6}$ For example in 2001, the Otago University Foreign Policy School hosted a seminar that reflected on the trans-Tasman relationship and came to the sobering conclusion that the two countries were drifting apart. ${ }^{7}$ Despite a sophisticated relationship, in a number of areas the two countries were addressing global and regional challenges differently, and regardless of a complex array of official and non-official interactions there was not a great deal of joint bilateral activity. The establishment of ANZLF was testament to the recognition that bilateral relations between Australia and New Zealand were strained and lacked the backing and influence of a supportive constituency.

A decade on, there has arguably been a great deal of policy and institutional convergence between Australia and New Zealand. There has been an increased determination to not only align or harmonise regulatory, financial and business frameworks, but also more concerted and robust efforts to cooperate on the global stage. There has also been a positive change in overall elite attitudes that has enabled the New

\footnotetext{
4 Jackson, Margaret and McDonald, Kerry. “The Australia New Zealand Leadership Forum”. Communiqué. 15 May 2004.

5 Allen, John and McGeoch, Rod. "Submission to the Australia's Future Tax System Review". 25 September 2008 .

6 See for example: Catley, Bob (ed.) New Zealand-Australia Relations: Moving Together or Drifting Apart? (Dark Horse Publishing. Wellington 2002). Barry, Michael and Wailes, Nick. "Revisiting the Australia-New Zealand Comparison”. New Zealand Journal of Employment Relations. Vol. 17. No. 3. 2005. Bradford, Max. "Why Have New Zealand and Australia Drifted Apart?" in Bruce Brown (ed.) New Zealand-Australia Relations: Where are we going? (New Zealand Institute of International Affairs. Wellington 2001). Harrigan, Nicholas and Goldfinch, Shaun. “A Trans-Tasman Business Elite?” Journal of Sociology. No. 43. No. 4. 2007, p. 378. James, Colin. "Two countries diverging”. The New Zealand Herald. 23 October 2001. Longdin, Louise. "Parallel Importing Post Trips: Convergence and Divergence in Australia and New Zealand". The International and Comparative Law Quarterly. Vol. 50. No. 1. 2001. New Zealand Foreign Affairs, Defence and Trade Committee. "Inquiry into New Zealand's Economic and Trade Relationship with Australia" (New Zealand Parliament. Wellington 2002). Patman, Robert. "Globalisation and Trans-Tasman Relations: Integration or Divergence?” Australian Journal of International Affairs. Vol. 55. No. 3. 2001. True, Jacqui and Devetak, Richard. "Diplomatic Divergence in the Antipodes: Globalisation, Foreign Policy and State Identity in Australia and New Zealand". Australian Journal of Political Science. Vol. 41. No. 2. 2006, pp. 241-256.

7 Brown. Ibid, p. 4.
} 
Zealand Government to continue its initiatives to refocus the relationship and reenergise the level of cooperation. Particular attention has been given to the SEM project by governments and business alike.

Yet according to a number of participants and other interested parties, the ANZLF can only lay claim to a small number of successful initiatives. Non-official participants who have approached the Forum anticipating an increased ability to shape broad policy and effect top-down change have largely been disappointed. Consequently there has been a growing frustration and declining interest from participants with the Leadership Forum's process and structure. Has the Forum really made a difference to the bilateral relationship? The analysis that follows suggests that most analyses underestimate the intangible impact and influence of the Forum and its process. It has been important. This is the second assumption challenged.

The third argument made in this thesis is to suggest that in spite of increased non-governmental activity in the bilateral relationship, the trans-Tasman relationship remains largely state-centric and intergovernmental. ${ }^{8}$ Within international relations and political science there has been a trend to characterise non-governmental actors (particularly corporations) as drivers of economic 'globalisation'. 9 Yet, greater non-governmental involvement in what has traditionally been official diplomatic and political channels focused on policy related reform does not necessarily mean the "rolling back of the state". Rather, what we are seeing is the emergence of new forms of governance that draw on alternative resources and/or build strategic relationships between governments and a range of non-state actors to achieve state (that is governments, official agencies and other government sanctioned bodies) objectives. One mechanism to do so is non-official dialogues. As Wallington et al have summarised, it is about "states governing better rather than less". ${ }^{10}$ Such a view is supported by this study of the ANZLF, which

\footnotetext{
8 State-centrism is an approach to international relations that posits governments and the broader set of agencies and public bodies together constitute the state. It assumes that states are the central actors in governance processes. From this perspective, states are attempting to expand their governing capacities, not only by strengthening central state institutions, but by forging new partnerships with a range of social actors. Bell, Stephen and Hindmoor, Andrew. Rethinking Governance: The Centrality of the State in Modern Society (Cambridge University Press. Oxford 2005).

9 For example, David Korten argued that economic globalisation has handed corporations and financial institutions responsibility for the public good, shifting power away from governments and "concentrating massive economic and political power in the hands of an elite few..." Korten, David C. When Corporations Rule the World (Earthscan Publications. London 1995), p. 12.

10 From a state-centric position, the term governance is defined as "the tools, strategies, and relationships used by governments to help govern”. Bell and Hindmoor. Ibid, p. 2. Wallington, T., Lawrence, G. and Loechel, B. "Reflections on the Legitimacy of Regional Environmental Governance: Lessons from Australia's Experiment in Natural Resource Management”. Journal of Environmental Policy and Planning. Vol. 10. No. 1. 2008, pp.
} 
concludes that despite the involvement of a wide range of non-state actors, the nature and pace of trans-Tasman economic and institutional integration remains driven by, and subject to, the most senior levels of government. Therefore, in the context of the present study, the close relationship between officials and the business-led forum poses questions around whether processes like the ANZLF have substantive and independent agendas for change, or whether they only represent and legitimise established government policy.

\section{Research Questions}

Surprisingly, given that it is now almost a decade old and has attracted considerable media attention, the ANZLF has been the subject of limited scholarly research. ${ }^{11}$ Some journalistic work has surrounded each Forum, but little in the way of academic scrutiny exists. As such, this thesis takes a fairly broad approach to the Forum's activities and modalities to offer an analytic 'first cut'. In order to appraise the ANZLF's purpose, impact and dynamism two central research questions are asked: What is the role of the ANZLF? How much influence does the ANZLF exert on the trans-Tasman relationship and economic integration policy process?

\section{Why This Research Is Important}

A close examination of both the ANZLF and the trans-Tasman relationship generally is overdue because since 2004 Australia and New Zealand have been cooperating at an unprecedented level. This thesis places the ANZLF in the context of this period of change and intense interaction. It seeks to fill a gap in the literature by providing a detailed historical account of the ANZLF's emergence, activities and its participants from its founding in 2004 until 2010. This is an important but neglected aspect of contemporary trans-Tasman diplomacy and it reveals some interesting insights about the way in which New Zealand deals with its most important partner. The case also speaks to the broader importance of

$1-30$.

11 Exceptions are Professor Peter Hempenstall, and Sir Frank Holmes who have both written commentaries on the earlier ANZLF meetings. Holmes covered the inaugural Forum in 2004. Hempenstall provided a detailed account of the 2004, 2005 and 2006 Forums. Academic Shaun Goldfinch has made valuable contributions to analysing the trans-Tasman business elite and has touched on the ANZLF. See for example: Mein Smith, Philippa; Hempenstall, Peter and Goldfinch, Shaun. Remaking the Tasman World (Canterbury University Press. Christchurch 2008). Harrigan and Goldfinch. Ibid. In contrast, and reflecting the asymmetry of the relationship, there has been very little Australian academic or public discussion of the ANZLF. 
"track-two" dialogues, which are increasingly being seen as models for managing other important relationships.

\section{Research Challenges}

The lack of existing scholarship presented some important challenges for this research. Excluding some political commentary there was scant information available regarding the ANZLF. ${ }^{12}$ Very few documentary sources exist detailing the Forum's emergence. This meant that the most important source for information was interviews with Forum participants and stakeholders. Yet, this was not without its own challenges. What became apparent during these interviews was that the structure or history of the Forum was not clear to a large number of ANZLF participants themselves. As one participant noted, and others concurred: "All those things like who comes, how do ideas get put forward, how do they get taken up, who takes them up, is not terribly clear to anybody, not even the participants at the forum". ${ }^{13}$ This acute lack of textual sources and the absence of a settled version of events presented a challenge as I set about trying to paint a picture of the Forum upon which to base a critique.

\section{Research Methodology}

To comment on and understand the numerous and complex issues on the ANZLF agenda is no easy task. The input of participants has been crucial, and their experiences with the ANZLF have been used in an inductive way to build a qualitative narrative. This analysis draws on an extensive number of semi-structured personal interviews with former and current ANZLF participants, including co-Chairs, business leaders, former ministers and government officials. In selecting interview subjects it was intended to discuss the ANZLF with as wide a range of past and present attendees as possible. ${ }^{14}$ Participants who had attended all or most meetings were encouraged to be interviewed.

Fifty-two interviews with Forum participants, and former and current co-Chairs,

12 Fran O'Sullivan from the New Zealand Herald has contributed a plethora of insightful articles on every ANZLF meeting (particularly between 2004 and 2007). Colin James and Mark Peart have also made some significant contributions. Between 2004 and 2010, the National Business Review published approximately ten articles that focused on the ANZLF.

13 New Zealand business executive. Interview conducted April 2010.

14 While most of those interviewed have consented to having comments directly attributed to them, this thesis is careful to exercise discretion in directly naming sources. Exceptions are made in cases where opinions were widely known, or where a comment or quotation required validity or some particular emphasis. 
were conducted in person in Auckland, Canberra, Napier, Sydney and Wellington, as well as by telephone (see Appendix One for a list of interviewees). ${ }^{15}$ Of the fifty two who accepted, twenty three were from the business sector, and three were politicians (Keith Locke, Hon. Jim Sutton and Rt. Hon. Winston Peters). There were also eight government officials (including two former Australian High Commissioners to New Zealand, Bob Cotton and Dr Allan Hawke, and a former New Zealand High Commissioner to Australia, Simon Murdoch), three unionists, ten academics, three political commentators, and a former co-Chair's personal assistant. Of the five former and current co-Chairs, four were available to be interviewed (John Allen, Kerry McDonald, Rod McGeoch AM and James Strong). Twenty of the interviewees had served on the Australian delegation and twenty four had served on the New Zealand delegation (and one, Geoff Ricketts, Chairperson of Lion Nathan, had served on both).

Interviews were conducted using a semi-structured interview technique that typically used open-ended questions, allowing for flexibility and freedom in response. As well as a number of questions designed for each particular participant which related to their field of expertise, position and depth of ANZLF experience, there was a set of standard questions asked of every participant in order to garner specific quantitative information (see Appendix Two). The number of fora attended and the scope of each participant's attendance (such as belonging to steering committees or working groups or acting as a co-Chair) are examples of factors that shaped the interviewee questioning.

In addition to primary sources, secondary information for this thesis was also gathered by published material on the trans-Tasman relationship. This includes books, official documents, reports, pre-forum correspondence, briefing papers, and newspaper articles. Fran O’Sullivan's numerous and insightful political commentaries were particularly important, as was a personal discussion with her in 2009. Using multiple sources has made it possible to compare accounts and to reduce the risk that recollections could be skewed by an interviewee's faulty memory or by self-serving accounts. ${ }^{16}$

\footnotetext{
15 Of the two hundred and fifty eight participants that have attended an ANZLF meeting as an official delegate between 2004 and 2009, one hundred were invited to be interviewed, and forty four accepted. There were also eight interviewees that were not participants but had a relationship to the ANZLF or the Australia New Zealand Business Council, such as Hon Jim Sutton (former Minister for Trade Negotiations) and a number of former Australia New Zealand Business Council executives. Also interviewed were Keith Locke (who served on New Zealand Foreign Affairs, Defence and Trade Committee's "Inquiry into New Zealand's Economic and Trade Relationship with Australia"), an official from the New Zealand Ministry of Foreign Affairs and Trade official, two Australian Department of Foreign Affairs and Trade officials, and a former personal assistant to a ANZLF co-Chair.

16 Broman, Matilda. "Taking Advantage of Institutional Possibilities and Network Opportunities". Lund Political Studies. No. 152. 2008.
} 


\section{Structure of the Thesis}

This thesis is structured into five chapters. Chapter one sets out a conceptual framework for thinking about the ANZLF. First, this chapter discusses the role of theory in the context of this thesis. Second, it suggests that non-official diplomacy can be either a transformative mechanism for non-governmental actors and related policy networks and communities that can lead to new governing arrangements, or a diplomatic instrument for states to widen their governing capacity. Non-official diplomacy is divided into a number of "tracks", which are outlined, and the level of independence and interaction between "tracks" and specific actors is discussed. The purpose of this chapter is to outline a framework for thinking about the two levels of the ANZLF: the actual event, its form and attendees; and the trans-Tasman and domestic contexts in which it operates.

Chapter two provides an historical overview of how the business-led dialogue arose out of a New Zealand diplomatic initiative in 2004 with the goal of reenergising the bilateral relationship by incorporating a wider set of stakeholders. Differences in foreign and defence policies are examples of the divergence that marked a difficult time in the relationship and became key points of focus for both New Zealand politicians and the Ministry of Foreign Affairs and Trade.

The background against which the ANZLF's inception took place suggests that the ANZLF was not the result of business lobbying or trans-Tasman corporate interests as some scholars have suggested. ${ }^{17}$ Rather, the thesis argues that the ANZLF was borne out of three key drivers: New Zealand's desire to strengthen the relationship by expanding the Australia New Zealand Closer Economic Relations Trade Agreement; a joint government interest to form a stronger economic grouping in order to influence the changing Asian economic architecture; and a diplomatic motivation to mitigate negative publicity and 'mend broken fences'. With the traditional diplomatic tools exhausted, non-official diplomacy was considered an appropriate means through which to advance a number of political and economic goals.

The third chapter explores the organisational form and modalities of the ANZLF and the type of participants who have been involved. Specifically, it highlights how non-official diplomacy has benefited New Zealand by informing and influencing an

17 For instance, Harrigan and Goldfinch argue that: "the formal impetus for the Forum came from a letter in early 2004 by two of the most prominent business leaders in Australia and New Zealand: Kerry McDonald, Chair of the Bank of New Zealand, and Margaret Jackson, Chair of Qantas". Harrigan and Goldfinch. Ibid, p. 376. 
Australian audience to appreciate that New Zealand has its own rationales and interests for economically integrating with Australia. Indeed, the ANZLF is so important to the New Zealand government that there have been difficulties for the business-led forum to maintain a level of autonomy and independence. As such, it is shown that the non-official process has had a great deal of New Zealand governmental oversight and nurturing which has produced a number of significant political benefits, including an increase in positive attitudes and perceptions at the elite level, but conveniently narrowed the discussions and outcomes to smaller issues. Chapter three also highlights the Forum's key role as a constituency building mechanism that has facilitated the broadening and deepening of people-people networks.

Chapter four details the way in which the ANZLF has evolved over several meetings since 2004. As the ANZLF reached its sixth meeting in 2009, a remarkable change in general attitudes and perceptions is notable. The first two meetings were particularly useful for clearing the air on issues that had generated some resentment and distrust. The procession of six Leadership Forums highlights and coincides with an increased maturity (that is, integrative rather than divergent) in the relationship generally, and the Forum in particular, and a growing assertiveness and boldness from New Zealand participants in dealing with their Australian counterparts. From an initial position of suspicion by political leaders and a determination by governments to tightly manage their national delegations, we can trace a trajectory of an increasing collegiality among elites, and stronger ministerial participation at the Forum. Particularly notable is a shift from an introspective agenda focused on single market issues to an outward focus on areas and initiatives in the wider world where Australia and New Zealand can collaborate conjointly.

Finally, the fifth chapter returns to the three assumptions mentioned above. It offers some concluding remarks on the role, value and influence of the ANZLF, arguing that the ANZLF is a part of a larger diplomatic process aimed at transforming perceptions through trust and relationship building, whilst indirectly assisting governments in solving complex policy issues. Indeed, as a communication and feedback mechanism the ANZLF has not only been useful for New Zealand's goal of building a collegial and supportive network of Australian elites predisposed towards a greater understanding of New Zealand perspectives - it has also been an important part of improved trans-Tasman relations, and its activities deserve closer scrutiny from analysts and scholars. 


\section{Chapter One}

\section{Conceptualising the Australia New Zealand Leadership Forum}

\section{Introduction}

This chapter provides a conceptual framework for thinking about the Australia New Zealand Leadership Forum (ANZLF) in the broader context of the trans-Tasman relationship. First, it discusses the role of theory and a conceptual framework in the context of this thesis and research, particularly by drawing on international relations (IR) and diplomatic theory from a state-centric perspective. By state-centric, I take the view of both non-official diplomacy and economic integration in trans-Tasman terms being largely conducted by, and for the benefit of, government. In spite of an elevated role played by non-governmental actors in trans-Tasman bilateral affairs, from this perspective authority and policymaking has remained centralised, and economic and institutional integration proceeds at the discretion of high level politicians rather than non-governmental actors overtly influencing the policy agenda.

Second, this chapter explores how non-official diplomatic channels are divided into a number of "tracks"; and questions the extent of influence that both official and non-official participants have on agenda-setting and policymaking processes. Some scholars argue these non-official actors and processes play an important role in transnational cooperation primarily through the development of trust among members which can lead to new political, economic and institutional arrangements. ${ }^{18}$ Conversely, others believe these processes have a limited impact on policy or politicians, and can often resemble mere "talkfests". ${ }^{19}$ In short, there is a questioning of whether unofficial diplomatic endeavours function primarily as an instrument of states or principally operate as a transformative agent for non-officials and various sectors of civil society. ${ }^{20}$

\footnotetext{
18 Harris, Stuart. "Policy Networks and Economic Cooperation: Policy Coordination in the Asia-Pacific Region". The Pacific Review. Vol. 17. No. 4. 1994. Katsumata, Hiro. "The Role of ASEAN Institutes of Strategic and International Studies in Developing Security Operations in the Asia-Pacific". Asian Journal of Political Science. Vol. 1. No. 3. 2003, pp. 93-111.

19 Capie, David. "When does track two matter? Structure, agency and Asian regionalism". Review of International Political Economy. Vol. 17. No. 2. 2010, pp. 291-318. Fensom, Anthony. "Rudd's Asia-Pacific plan lost at sea?" The Diplomat. 31 May 2010. Jones, D. M. and Smith, M.L.R. "Making Process not Progress: ASEAN and the Evolving East Asian Regional Order”. International Security. Vol. 32. No. 1. 2007, pp. 148-184.

20 Kurbalija, Jovan. Modern Diplomacy (The Mediterranean Academy of Diplomacy. Athens 1998).
} 


\section{The Role of Theory}

As no in-depth studies or analyses of the ANZLF have been previously undertaken, this research was approached in a predominantly descriptive-inductive way, a method typically employed in the field of contemporary history. ${ }^{21}$ A descriptive-inductive methodology is an empirical approach that begins with observations and qualitative statements, and moves cautiously towards generalised conclusions. As Dennis Kavanagh puts it, by exploring the events, actors, and institutions in a descriptive and qualitative way, we are able to "systemically describe and analyse phenomena that have occurred in the past and which explain contemporary political phenomena...the emphasis is on explanation and understanding, not formulating laws". ${ }^{22}$ This method stands in contrast to a hypothetico-deductive approach, which would demand the development of precise hypotheses before the data collection took place, and the testing of those hypotheses to be either true or false by a process of falsification. This is a method more properly suited to scientific research or a more stable collection of data.

The absence of any one story or perspective to explain the ANZLF and its role in the bilateral relationship means the starting point must be the empirical data. The amalgamation of participants' observations is gradually unfurled, which enables an ensuing search for patterns and generalisations that can point to the operation of aspects of IR theory. A number of broad theoretical positions, which are set forth below, thus provide a backdrop to the ANZLF narrative. Inasmuch as the research is qualitative and inductive, the theories are not so much being tested, but are used to illuminate the shifting contours of the trans-Tasman relationship and the way in which the ANZLF contributes to and reflects those changes. There is no scientific "truth" to the Forum, but rather a picture of it that grows deeper and more detailed as perspectives are amalgamated, compared and played off against one another.

\footnotetext{
21 Butler, D.E. The Study of Political Behaviour (Hutchinson Publishing. London 1958), p.48. Contemporary history, in contrast to modern history (a term that most Western historians apply to the entire period since the French Revolution), is a history that provides an explanatory or interpretive background for events still being contested or whose ramifications are still affecting current political or social development. It generally comprises narratives and explanations for events and peoples that may have an impact on policy decisions. Anthony Kennedy noted that "contemporary history bears an intimate relationship to the choices facing the society in which the historian is rooted". Anthony M Kennedy. www.pagerankstudio.com (Accessed: 12/12/10).

22 Kavanagh, D. “Why Political Science needs History?” Political Studies. Vol. 39. No. 3. 1991, pp. 479-495. Also see: Glaser, Barney and Strauss, Anselm. The Discovery of Grounded Theory: Strategies for Qualitative Research (Aldine de Gruyter. New York 1967), p. 3.
} 


\section{Conceptual Framework}

This thesis looks at the ANZLF through the conceptual lens of unofficial diplomacy which stems from a paradigm that divides diplomatic channels between official and unofficial activities. ${ }^{23}$ The numerous track-typed meetings have their own distinctive styles, depending on the various participants and the type of interaction the respective governments, organisations or individuals involved intend to create. ${ }^{24}$ There exists varying literature on the effectiveness of unofficial diplomatic processes and the role that, for example, individuals, networks, interest and business groups, lobbies, think-tanks or policy communities play in such endeavours, and to what extent, if any, they are accorded significant influence in agenda-setting and/or policymaking processes. ${ }^{25}$

\section{Non-State Involvement in Diplomatic Processes}

There are at least three interesting areas of theoretical and empirical enquiry that explain the role and function of participants in unofficial diplomacy. Central to these conceptualisations is a questioning of governance and whether the involvement of non-governmental actors in international affairs have prompted centralised forms of government to give way to decentralised and informal modes of communication and decision-making. ${ }^{26}$ One argument is that the ANZLF reflects the consolidation of trans-Tasman and/or national policy communities; whereby the meetings are composed of various policy experts and policy entrepreneurs from both Australia and New Zealand. Similarly along these lines is the suggestion that the ANZLF has facilitated the expansion and greater involvement of policy networks in bilateral trans-Tasman affairs. Policy networks, according to Grace Skogstad, "constitute a crucial lynchpin in the capacity of governments to adjust their economies and public policies to the constraints and

\footnotetext{
23 Kraft, Herman. "Track Three Diplomacy and Human Rights in Southeast Asia". Global Networks: A Journal of Transnational Affairs. Vol. 2. No. 1. 2002, pp. 49-64.

24 McKay, Pia ."Young Leader reflects on Track II trip to India and Malaysia". Asia New Zealand Foundation. www.asianz.org.nz/our-work/young-leaders/out-and-about/track2 (Accessed: 15/01/11). 25 See for example: Pigman, Geoffrey. "Making Room at the Negotiating Table: The Growth of Diplomacy between Nation-State Governments and Non-State Economic Entities". Diplomacy and Statecraft. Vol. 16. No. 2. 2005, pp. 385-401. Stone, Diane and Nesadurai, Helen E.S. "Networks, Second Track Diplomacy and Regional Cooperation: The Experience of Southeast Asian Think Tanks". Paper presented to the Inaugural Conference on Bridging Knowledge and Policy. The Global Development Network, Bonn, Germany, 5-8 December 1999.

26 Kaiser, Wolfram; Leucht, Brigitte, and Gehler, Michael. "Transnational Networks in European Integration Governance" in Kaiser, Leucht and Gehler (eds.) Transnational Networks in Regional Integration: Governing Europe (Palgrave Macmillan. Basingstoke 2010).
} 
opportunities posed by globalisation". ${ }^{27}$ Second, a body of literature popular in European integration theories points to the emergence of multilevel governance, where decision-making and influence over policy are dispersed between subnational, national and supranational actors. ${ }^{28}$ Finally, there are state-centric approaches that assume states are unitary actors that guide economic foreign policy by prudence and self-interest. ${ }^{29}$ From this perspective, there is a marked reluctance by states to cede sovereignty or decision-making to non-state and/or non-elected individuals or groups.

More broadly, much of the mainstream IR literature has focused on the dichotomy between what can be broadly defined as state-centric and pluralistic society-centred approaches. ${ }^{30}$ Realists have espoused the long held notion that in spite of increased interactions with non-governmental actors and groups, states are reluctant to share or delegate authority and decision-making power to non-governmental actors. Instead, states often choose to employ the resources and skills of actors outside of government for their own ends, and specific outcomes are the result of calculated and rational behaviour of states. Bearing in mind an intergovernmental perspective ${ }^{31}$ that accounts for the impact of domestic politics on government preferences and the acknowledgement that non-governmental actors are important players in their own right, a state-centric approach essentially views state authority as central to most governing strategies. ${ }^{32}$ States act as gate-keepers of economic, political and institutional developments, and it is assumed that national governments control the speed and form of economic integration with other states. ${ }^{33}$ There can be periods of converging governmental preferences or periods of inertia

\footnotetext{
27 Skogstad, Grace. "Policy Networks and Policy Communities: Conceptual Evolution and Governing Realities". Paper prepared for the workshop on "Canada's Contribution to Comparative Theorizing". Annual Meeting of the Canadian Political Science Association. University of Western Ontario. 2 June 2005.

28 Marks, Gary and Hooghe, Liesbet. "European Integration from the 1980s: state-centric vs. multilevel governance”. Journal of Common Market Studies. Vol. 34. No. 3. 1996, pp. 341-378.

29 Gilpin, Robert. “The Politics of Transnational Economic Relations.” in R. O. Keohane and J. S. J. Nye (eds.) Transnational Relations and World Politics (Harvard University Press. Cambridge, MA 1972). Morgenthau, Hans J. Politics Among Nations: The Struggle for Power and Peace (Alfred A. Knopf. New York 1978).

30 Bell, Stephen; Hindmoor, Andrew and Mols, Frank. "Persuasion as Governance: A state-relational perspective”. Public Administration. Vol. 99. No. 3. 2010, pp. 851-870. Bell and Hindmoor. Ibid.

31 Intergovernmentalism is defined as "an approach to integration that treats states and national governments in particular, as the primary actors in the integration process. Intergovernmentalism is distinctive from realism and neo-realism due to its recognition of both the significance of institutionalisation in international politics and the impacts of processes of domestic politics upon governmental preferences”. Rosamond, Ben. Theories of European Integration (St. Martin's Press. New York 2000). Also, see for example: Moravcsik, Andrew. "Taking Preferences Seriously: A Liberal Theory of International Politics". International Organization . Vol. 51. No. 4. 1997, p. 516. Moravcsik, Andrew. "Liberal Intergovernmentalism and Integration: A Rejoinder”. Journal of Common Market Studies. Vol. 33. No. 4. 1995.

32 Bell and Hindmoor. Ibid. Bell, Hindmoor and Mols. Ibid.

33 Bell and Hindmoor. Ibid. Moravcsik . "Liberal Intergovernmentalism and Integration: A Rejoinder". Ibid.
} 
due to diverging national interests.

A commitment to the analytical centrality of the state in the study of international politics has provoked a great deal of criticism in mainstream IR scholarship. ${ }^{34}$ It has been challenged by the purported reconfiguration of authority and decision-making between state and non-governmental actors. ${ }^{35}$ Scholars interested in economic integration have attempted to examine how globalisation facilitates the multilevel diffusion of political authority to sub-national and transnational actors. ${ }^{36}$ Others focus on the proliferation of non-governmental networks and actors as policy networks. ${ }^{37}$ A "policy network" is a useful generic term for a variety of different conceptual models such as policy communities, epistemic communities, transnational policy groups, advocacy coalitions, discourse coalitions and knowledge networks, for example. ${ }^{38}$ We may look at the work of Peter Haas, Margaret Keck and Kathryn Sikkink, Paul Sabitier, Thomas Risse, and Diane Stone, all of whom have argued for the importance of what Scott Burchill calls "a mode of governance that incorporates actors from both inside and outside of government to facilitate decision-making and implementation". ${ }^{39}$

From a society-centred perspective, increased pressure for economic integration due to the proliferation of globalised production and markets have placed considerable pressure on governments to collaborate more closely with other actors on the world stage. ${ }^{40}$ In this view, the political, economic and trade related aspects of foreign policies have became the shared objective of both governments and the private sector. At the heart of this understanding is the effective expansion of existing links through networking,

\footnotetext{
34 Lacher, H. "Putting the state in its place: the critique of state-centrism and its limits". Review of International Studies. Vol. 29. Vol. 4. 2003, pp. 521-541.

35 Lacher. Ibid. Skogstad. Ibid.

36 Hooghe, Liesbet and Marks, Gary. Multi-Level Governance and European Integration (Rowman and Littlefield. Boulder 2001).

37 Peterson, J and O'Toole, L.J. "Federal governance in the US and the EU: A policy network perspective" in K. Nicolaidis and R. Howse (eds.) The Federal Vision: Legitimacy and Levels of Governance in the United States and the European Union (Oxford University Press. Oxford 2001).

38 For example, the concept of 'epistemic communities' was developed by Peter Haas to describe how policy-making can become dominated by 'network[s] of professionals with recognized expertise and competence in a particular domain', particularly ones subject to internationalised policy-making. Haas, Peter M. "Epistemic Communities and International Policy Coordination”. International Organization. Vol. 46. No. 1. 1992, pp. 1-35. Or, consider Sabatier's advocacy coalition framework, which holds that policy shifts usually occur when the sectoral agenda is seized by overtly political networks consisting of various kinds of policy activist, including public officials representing multiple levels of government, who 'share a particular belief system'and work together over relatively long periods of time (two years or more) to force policy change. Sabatier, P. A and Jenkins-Smith, H.C. (eds.) Policy Change and Learning: An Advocacy Coalition Approach (Westview Press. Boulder 1993).

39 Burchill, Scott. Australia's International Relations: particular, common and universal interests (Australian Institute of International Affairs. Deakin University. Melbourne 1994), p. 19.

40 Bell and Hindmoor. Ibid. Bell, Hindmoor and Mols. Ibid. Hooghe and Marks. Ibid.
} 
especially policy and business communities. A central proposition is that a growing number of policy related decisions are articulated and driven through self-organising policy networks, constituting a shift from government to governance. ${ }^{41}$

Policy networks may be loosely structured but still capable of engaging in collective action between government and civil society associations and interest groups in specific policy areas. ${ }^{42}$ A network is the linking process within a policy community or between one or more communities. ${ }^{43}$ A policy community identifies those actors and potential actors drawn from policy circles that share a common policy focus and are in a position to potentially influence policy decisions, operating with, as Rod Rhodes claimed: "significant autonomy from the state". ${ }^{44}$ Policy communities often develop in established, stable and predictable policy environments, particularly liberal democracies whereby participants share basic values, a set of casual and principled beliefs, and a specific interest in certain policy sectors, and membership is generally stable, tending to persist over time. ${ }^{45}$

Multilevel governance is a broader metaphor to depict a mature stage of an emerging polity whereby the number of significant actors has widened and political action occurs at various levels of governance. ${ }^{46}$ Conceptually multilevel systems rest on a society-centred approach whereby the key players are not necessarily states or national governments, but comprise of technocrats, influential economic elites and officials as well as elected leaders. A multilevel conceptualisation of governance contends that national governments may play the lead role as a key organising agent, but they are unable to control domestic actors on the global or bilateral stage. ${ }^{47}$ As Ian Bache and Matthew Flinders state: "while multi-level governance remains a contested concept, its broad appeal reflects a shared concern with increased complexity, proliferating jurisdictions, the rise of non-state actors, and the related challenges to state power". ${ }^{48}$ In this view, authority and policymaking influence are shared across multiple levels of governance and decision-making is dispersed. It accounts for, and highlights influences on, different parts

\footnotetext{
41 Peterson, John. Policy Networks (Institute for Advanced Studies. Vienna 2004). Bell and Hindmoor. Ibid, p. 4.

42 Marsh, D. and Rhodes, R. A. W. Policy Networks in British Government (Clarendon Press. Oxford 1992). 43 Ibid.

44 Rhodes, Rod. Understanding Governance: Policy Networks, Governance, Reflexivity and Accountability (Open University Press. Buckingham 1997), p. 52.

45 Evans. M and Davis, J. "Understanding policy transfer: a multi-level, multidisciplinary perspective". Public Administration. Vol. 77. No. 2. 1999, p. 372.

46 Rosamond. Ibid, p, 201.

47 Hooghe and Marks. Ibid.

48 Bache, Ian and Flinders, Matthew V. Multi-level Governance (Oxford University Press. New York 2004), pp. 4-5.
} 
of the policy process. In the context of the trans-Tasman world, a multilevel arrangement would see significant institutional development and engagement between politicians, officials, and the wider private sector at both the trans-Tasman and domestic levels "functioning as interlocking working relationships". ${ }^{49}$

While the latter perspectives seek to downplay the authority of the state, it is important to note that certain policy networks and multilevel governance do not necessarily undermine state power, but may in fact enhance it. As Bob Jessup argues, "a shift in governance can enhance the capacity to project state power and achieve state objectives by mobilizing knowledge and power resources from influential non-governmental partners or stakeholders". ${ }^{50}$ This thesis finds empirical evidence that the fifth New Zealand Labour Government (1999 to 2008) orchestrated a shift in governance in some areas and that this enhanced its own power. In some instances it is observable that the ANZLF has been most useful for politicians and officials to draw on views, expertise and information, and mobilise non-governmental actors to favour agreed positions. It is in this way that the theoretical characters in this interplay of ideas tend to merge into the same beast: it is plausible that devolving power and influence to private and non-official actors may be advantageous to central government and at times form a part of a state strategy. One contemporary means to practically apply these types of strategies has been non-official diplomacy.

\section{Diplomacy}

In its most traditional definition, diplomacy is "the management of international relations by negotiation; the method by which these relations are adjusted and managed by ambassadors and envoys; the business or art of the diplomatist", implying that only accredited persons represent states, groups or nations in the international arena. ${ }^{51}$ However, it has become apparent that traditional forms and functions of diplomacy are increasingly complex and non-governmental actors have encroached on traditionally diplomatic territory. Governments and diplomats alike have become more concerned with the creation and/or management of transnational networks, political movements, foreign

\footnotetext{
49 Josselin and Wallace. Ibid, p. 94.

50 Jessop, Bob. "Multi-level Governance and Multi-level Meta-governance" in Bache and Flinders. Ibid, p. 65.

51 Nicolson, Harold. Diplomacy (Oxford University Press. London 1963).
} 
publics and companies. ${ }^{52}$ One way to manage theses relations has been through non-official dialogues. The diversity of unofficial diplomatic activity, such as unofficial dialogues, over the past thirty years has led to extensive scholarly attention in the theoretical literature, and its uses have continuously evolved to convey specific ideas that reflect the changing nature of diplomacy. ${ }^{53}$ A more contemporary and flexible definition that responds to the developments, giving emphasis to the increasing role played by non-governmental actors through such processes is: "the mechanism of representation, communication, and negotiation through which states and other international actors conduct their business". ${ }^{54}$

In diplomatic scholarship, the growing popularity of unofficial diplomacy has provided compelling approaches to conceptualise the relationship between states and non-governmental actors. Such unofficial interactions are often referred to by a number of "track" metaphors to describe the level of non-state involvement in diplomatic affairs. Each has their own distinctive styles, depending on the various participants, the chairperson(s) and the prime purpose of the endeavour. They include but are not limited to track-one, track-two, track-one-and-a-half ${ }^{55}$ and track three diplomacies. ${ }^{56}$ Each track describes the various forms and levels of dialogue, interaction and activities that can take place, and the various approaches used to manage different kinds of societal or conflicting sectors. Each type of diplomatic effort proceeds along a different track, often with intersecting points to other tracks, and are individually tailored to solve or advance a particular issue or cause. ${ }^{57}$ A prime distinction between types of unofficial diplomacy is those that help prepare, and others that attempt to determine, policy or political outcomes.

This form of interstate interaction can incorporate a wide range of individual actors and groups, including policy communities and networks, and other interest groups. The Asian region has tended to focus on security dialogues and therefore attracts a policy community focused on security issues, often comprised of politicians, military and civilian bureaucrats, and researchers. In contrast, in the Middle East these dialogues have revolved

\footnotetext{
52 Hocking, Brian. "Multi-Stakeholder Diplomacy: foundations, forms, functions and frustrations" (Diplo Foundation. Malta 2005).

53 Schiff, Amira. "Quasi Track-One Diplomacy: An Analysis of the Geneva Process in the Israeli-Palestinian Conflict”. International Studies Perspectives. Vol. 11. No. 2. 2010, pp 93-111.

54 Melissen, Jan. Innovation in Diplomatic Practice (Palgrave. New York 1999), p. xvii.

55 Nan, Susan Allen. "Track One and a Half Diplomacy: Searching for Political Agreement in the Caucasus" in Fari Fitzduff and Cheyanne Church (eds.) NGOs at the Table: Strategies for Influencing Policies in Areas of Conflict (Rowman \& Littlefield. Lanham 2004).

56 Kraft. "Track Three Diplomacy and Human Rights in Southeast Asia". Ibid.

57 Nan, Susan Allen. "Track 1 Diplomacy" in Guy Burgess and Heidi Burgess (eds.) Beyond Intractability (Conflict Research Consortium. University of Colorado 2003).
} 
much more around conflict resolution, mediation and relationship-building, and focused on achieving immediate and tangible outcomes. ${ }^{58}$

\section{Track-One Diplomacy}

Track-one diplomacy refers to official government-to-government diplomacy. That is, officially sanctioned interaction and communication that takes place between governmental officials, and representatives of inter-governmental organisations. ${ }^{59}$ The ASEAN Regional Forum is an example of a multilateral track-one event. Track-one diplomacy can be distinguished from unofficial interactions and activities. It is a state-centric approach to managing political relationships between any given countries and constitutes the canon of traditional diplomatic theory and the bulk of bilateral activity. ${ }^{60}$

Trans-Tasman relations have remained heavily dependent on the nature of personal relationships between individual leaders and ministers. Trans-Tasman track-one diplomacy takes place at formal meetings such as the annual Prime Ministers bilateral talks, and twice annual Foreign Ministers meetings, and are complemented by the CER Economic Ministers meeting, and separate meetings between the Ministers of Defence, the Treasurer and Finance Ministers. This often amounts to leadership diplomacy - whereby specific advances or problem solving are conducted by the highest of political offices through official visits to advance country-country relationships. ${ }^{61}$ In addition, there is widespread and extensive engagement between Australian and New Zealand Government agencies at officials' level, Parliamentary Committees, and through political party backchannels. ${ }^{62}$

\section{Track-Two Diplomacy}

Regionalisation has encouraged the growth of track-two processes in a range of forms, participants and objectives. ${ }^{63}$ Joseph Montville and William Davidson first used the term

\footnotetext{
58 Kaye, Dalia. Rethinking Track Two Diplomacy (Netherlands Institute of International Relations. Clingendael Diplomacy Papers. No. 3. The Hague 2005).

59 Nan. "Track 1 Diplomacy". Ibid.

60 Jönsson, Christer and Langhorne, Richard (eds.) Diplomacy. Vol. 1 (Sage Publications. London 2004).

61 New Zealand Ministry of Foreign Affairs and Trade. Bede Corry to John Allen "Background Paper for the 2008 Australia New Zealand Leadership Forum”. 4 June 2008.

62 New Zealand Ministry of Foreign Affairs and Trade. "Australia: Political Links". www.mfat.govt.nz/Foreign-Relations/Australia/2-Political-links/index.php (Accessed: 12/01/11). 63 Makito, Noda. "The Role of Nonstate Actors in Building an ASEAN Community" in Sekiguchi Sueo and Noda Makito (eds.) Road to ASEAN-10: Japanese Perspectives on Economic Integration (Japan Center for
} 
track-two diplomacy to explain the activities of, and contacts with, non-state actors (as private individuals or groups). ${ }^{64}$ They claimed the objective was to develop strategies, influence public opinion, and organise human and material resources in ways that might resolve or avert a conflict. This could extend from the "most apolitical cultural exchanges to psychologically focused political problem-solving meetings". ${ }^{65}$ The process may or may not involve actual negotiations but is often considered to be an "integral part of the negotiating process" to further a specific goal or proposal by paving the way for cooperation at the official level. ${ }^{66}$

Track-two diplomacy should, in theory, lack the direct involvement of official finances, negotiators or representatives. However, political involvement and support is necessary for a number of reasons, for example: to attract government attention to specific issues; to maintain a sense of relevance and purpose; and to avoid a "talkfest" of non-officials. Yet, while track-two dialogues depend on government linkages, it is recognised (some claim essential) ${ }^{67}$ that the process remains independent from official control and political manipulation. Herman Kraft claimed that too much official influence and involvement creates the "autonomy dilemma of track-two diplomacy". ${ }^{68}$ Kraft noted that dialogues that involve a close relationship between officials and non-officials can potentially stifle new thinking and critical contributions, and compromise the quality of analysis and discussion. From this view the level of autonomy and independence is important to preserve integrity and confidence in the process. Officials generally participate in a non-official capacity, although Helen Nesadurai and Diane Stone suggest that this is often a "polite fiction". ${ }^{69}$

\section{Non-State Elite Actors in Track-Two Diplomacy}

Although track-two dialogues do not often attract prime ministers, senior officials and chief executives, there is a general focus on organised dialogues to facilitate an influential

\footnotetext{
International Exchange. Tokyo 1999), pp. 167-194. Fukushima, Kiki. A Fate of Regionalism in East Asia and Northeast Asia. A View from Tokyo. (National Institute for Research Advancement. Tokyo 2006).

64 Davidson, William D and Montville, Joseph V. "Foreign Policy According to Freud". Foreign Policy. No. 45. Winter 1981-1982, p. 156.

65 Ibid.

66 Schiff. Ibid.

67 Kraft, Herman. "The Autonomy Dilemma of Track Two Diplomacy in Southeast Asia”. Security Dialogue. Vol. 31. No. 3. 2000, pp. 343-356.

68 Ibid.

69 Stone and Nesadurai. Ibid, p. 15.
} 
level of broad based elite attendance crossing government, academia, and business and community groups. They can also accommodate business lobbies or think tanks. Generally it is assumed that the intervenors and non-state attendees "hold no official title... but are close enough to the centre of power to have some sort of influence over decision-makers, political elite, and/or public opinion". ${ }^{70}$ There are exceptions, and a distinction can be made between bilateral and multilateral dialogues, for example the majority of participants at multilateral track-two security dialogues in Asia are drawn from middle or lower levels of society (in terms of power and influence). Bilateral track-two dialogues, on the other hand, such as the Australian American Leadership Dialogue (AALD) tend to focus on economic and political elites. Hugh White suggested one reason the AALD has become self-sustaining is that the focus on elites has meant that a number of senior and influential Americans elites serving on the American delegation attracts other Americans to participate - not because they want to talk with Australians - but to meet those senior American officials or participants. ${ }^{71}$

In a broad sense, elites can be defined as "simply people who are able, through their positions in powerful organizations, to affect national political outcomes individually, regularly and seriously. Elites thus constitute a nation's top leadership in all sectors political, business, unions, military, media, religious and intellectual". ${ }^{22}$ Although power cannot always be observed directly or measured accurately, there is a general assumption that power is located at the forefront of decision making positions of large and complex organisations, such as corporations, universities or governments, with power to affect organisational outcomes. ${ }^{73}$ In this context, the meaning of elite is not drawn from an analysis of social class but rather, as one scholar noted, a "term applicable to sets of identifiable human actors who exercise power and influence - or to put it another way, leadership - within a given setting". ${ }^{74}$

\footnotetext{
70 Kaye. Ibid, p. 7.

71 Interview with Hugh White, head of the Strategic and Defence Studies Centre. Australia National University. Interview conducted August 2010. Subsequently New Zealand has, since, 2007, had an annual United States - New Zealand Partnership Forum. Similar to the ANZLF, it is business-orientated but politically-led, closed door meeting, and like the AALD - New Zealand views it as a catalyst to obtain a free trade arrangement between the two countries, although the stated objective is to "build a value proposition for closer engagement between the two countries". For more information see: www.nzuscouncil.com/.../third us nz partnership forum (Accessed: 04/10/10).

72 Burton, Michael and Higley, John. "Elite Settlements" cited in Goldfinch, Shaun. Remaking New Zealand and Australian Economic Policy. Ideas, Institutions and Policy Communities (Victoria University Press. Wellington 2000), p. 220.

73 Higley, John, Deacon, Desley and Smart, Don. Elites in Australia (Routledge. London 1979), p. 3.

74 Holten, Robert J. Global Networks (Palgrave MacMillan. New York 2008), p. 183.
} 


\section{Hard Track-Two Diplomacy}

Track-two diplomacy can be divided into "hard" and "soft" tracks. ${ }^{75}$ Typically track-two diplomacy has traditionally been used to resolve deep-rooted and complex identity-based conflicts with the objective of negotiating political agreements. ${ }^{76}$ This is known as "hard track-two" and is conducted by informal intermediaries such as non-governmental organisations, academics, private citizens and elites. ${ }^{77}$ In hard track-two diplomacy, participants are encouraged to freely discuss sensitive issues that cannot be addressed in a formal setting, with the aim of "reaching a political agreement or understanding that will be acceptable to the conflicting parties". ${ }^{78}$ Hard track-two diplomacy has, for instance, been useful in the Balkans and the Democratic Republic of Congo where official diplomacy has proven difficult. ${ }^{79}$ These typed meetings can potentially be decision-making bodies aimed at negotiating or reaching a conclusion.

\section{Soft Track-Two Diplomacy}

In other track-two type fora, issues on the agenda may relate to policy and be aimed at policy-solving and constituency-building rather than reaching an agreement, and often characterised as "soft track-two" diplomacy. More recently, soft track-two diplomacy has become widely accepted and fashionable. It has gone beyond conflict resolution to become especially useful when track-one relations are troubled or strained, and in areas in need of constituency or confidence building, or simply to solve specific problems and address key challenges. ${ }^{80}$ Soft track-two diplomacy has a pre-emptive and cognitive approach to awareness building which Harold Saunders claimed is centred around dialogue "aimed at an exchange of views, perceptions and information among the parties to improve each others' understanding of the others positions and policies", by addressing and solving

\footnotetext{
75 Agha, Hussein; Feldman, Shai; Khalidi, Ahmad and Schiff, Zeev. Track 2 Diplomacy: Lessons from the Middle East (MIT Press. East Cambridge 2003), p. 3.

76 Kaye. Ibid, p. 6.

77 Naidoo, Sagaren. "The Role of Track Two Diplomacy in the Democratic Republic of Congo". African Journal on Conflict Resolution. Vol. 1. No. 2. 2000, pp. 85-104.

78 Schiff. Ibid, p. 99. Agha et al. Ibid.

79 Naidoo. Ibid.

80 Saunders, Harold. "Officials and Citizens in International Relationships: The Dartmouth Conferences" in V. Volkan; J. Montville, and D. Julius (eds.) The Psychodynamics of International Relations, Volume 2: Unofficial Diplomacy at Work (Lexington Books. Lexington 1990).
} 
policy issues. ${ }^{81}$ Potentially through soft track-two processes participants "may indirectly contribute to the formation of new national political priorities and policies". ${ }^{82}$ Depending on the circumstances or desired outcomes, the overall objective of soft track-two dialogues is to assist governments by encouraging and supporting the development of a certain process; developing policy initiatives and strategies; and/or for building alliances. ${ }^{83}$

Governments benefit from building strategic relationships with non-state actors. For example, constituency building is grounded in efforts to create ongoing and systemic political support through relationship building mechanisms, largely for political influence. ${ }^{84}$ In soft track-two processes the focus is on people-people relationships and links; the constituency building component is employed by informational and team building tactics with an emphasis on building trust. ${ }^{85}$ It works in several ways, such as by building personal bridges between non-officials themselves, between non-officials and officials, and between officials and politicians of different countries, and in many cases those serving on the same delegation. During non-official exchanges much of the relationship building takes place during dinner or in-between formal sessions. Building and nurturing a stakeholder base makes good political sense, yet it takes time to establish and generate. An Australian ANZLF participant stated:

\begin{abstract}
"The opportunity to spend time with all the sorts of delegates at the meeting is invaluable because maybe not there, but down the track there will be areas of mutual interest that will emerge that you can connect back to an individual or a conversation that you had at the Forum... It carries some political weight because those that are driving the agenda meet people that for them down the track can contribute to what they want to achieve at a later stage", ${ }^{86}$
\end{abstract}

Soft track-two processes that focus on constituency building have a socializing function. Through dialogue and interaction there is an attempted impact on perceptions and

\footnotetext{
81 Ibid.

82 Jones, Peter. "Filling a critical gap, or just wasting time? Track two diplomacy and regional security in the Middle East". Arms Control in the Middle East. No. 2. 2008.

${ }^{83}$ Kraft. "Track Three Diplomacy and Human Rights in Southeast Asia”. Ibid, p. 51.

84 Lord, Michael D. "Constituency building as the foundation for political strategy". Management Executive. Vol. 17. No. 1. 2003, pp. 112-121.

85 Ibid, p. 113. In relation to trust, Aaron Hoffman states that "By and large, scholars agree on the elements that a definition of trust must involve the willingness to take risks and the expectation that others will honor particular obligations". Hoffman, Aaron. "A Conceptualization of Trust in International Relations". European Journal of International Relations. Vol. 8. No. 3. 2002, p. 375.

86 Australian business executive. Interview conducted August 2010.
} 
attitudes on the part of participants (official and non-official alike) that may lead to a change in norms or policy, and the building of trust and cooperative habits. ${ }^{87}$ There is no agreed definition, although Alice Ba claims: "[Most] theorists agree that socialization involves convergence of some kind or modifications to behavior patterns such that an actor 'fits in' to a larger community". ${ }^{88}$ Soft track-two diplomacy is in many ways a function of social psychology, in terms of human relationships and changes in perception, and its importance should not be underestimated even between two countries who have, on the whole, a close and largely amicable relationship. ${ }^{89}$

Some scholars argue that there is the potential for soft track-two processes to achieve a large degree of shared understandings and consensus among its participants on difficult issues, yet this takes a great deal of time and is difficult to quantify. ${ }^{90}$ Socialization is an interactive and mutual process aimed at officials and non-officials alike to get to know each other and their positions. The assumption is that if the conflicting parties overcome their psychological obstacles and instead focus on the basis of shared interests, ${ }^{91}$ participants develop a keener appreciation of each other's perspectives, respective national standpoints and concerns, and can limit misperceptions or inaccurate assumptions about a regional neighbour. This process is most effective when the event is private, insulated and relatively un-politicised, therefore most track-two processes are conducted under the Chatham House Rule. ${ }^{92}$ The process is also effective when participants feel like they are rewarded for their time and have a sense of purpose for contributing, or get desired results.

\footnotetext{
87 Ba. Alice D. "Who's socializing whom? Complex Engagement in Sino-ASEAN Relations". The Pacific Review, Vol. 19 No. 2. June 2006, pp. 157-179. Checkel, Jeffrey. "Why comply? Social learning and European Identity Change”. International Organization. Vol. 55. No. 3. 2001, pp. 553-588.

88 Ba. Ibid.

89 Montville, Joseph. "Track Two Diplomacy: The Arrow and the Olive Branch." in V. Volkan; J. Montville, and D. Julius (eds.) The Psychodynamics of International Relations, Volume 2: Unofficial Diplomacy at Work (Lexington Books. Lexington 1990).

90 Ball, Desmond; Milner, Anthony and Taylor, Brendan. "Track 2 Security Dialogue in the Asia-Pacific: Reflections and Future Directions". Asian Security. Vol. 2, No. 3. 2006, pp. 180-281. Johnston, Alistair Iain. "Socialization in International Institutions. The ASEAN Way and International Relations Theory" in John Ikenberry and Michael Mastanduno (eds.) International Relations Theory and the Asia-Pacific (Columbia University Press. New York 2003), p. 125.

91 Schiff. Ibid, p. 3.

92 The Chatham House Rule constrains reportage in order to encourage openness, frank debate and the sharing of information within the meeting. The Chatham House website states: "When a meeting, or part thereof, is held under the Chatham House Rule, participants are free to use the information received, but neither the identity nor the affiliation of the speaker(s), nor that of any other participant, may be revealed". www.chathamhouse.org.uk/about/chathamhouserule/ (Accessed: 10/12/10). Regarding the restrictions of the Chatham House Rule at the ANZLF, see for example: Peart, Mark. "Comment on Australia New Zealand Leadership Forum”. New Zealand Management. Vol. 55. July 2008.
} 


\section{Track-Three Diplomacy}

Track-three diplomacy includes active organisations and individuals "not directly concerned with influencing official government policies" and more interested in building transnational social capital. ${ }^{93}$ Track-three generally involves non-elite and autonomous participants, groups or communities who may be marginalised in the policy process, for example non-governmental or transnational organisations, students, human rights groups or networks and coalitions who claim to represent these groups and peoples. ${ }^{94}$ Track-three contains specific or alternative agendas such as gender, human rights, and the environment. ${ }^{95}$ Finally, track-three fora are further from direct government interaction and policy involvement than other tracks.

Track-three diplomacy has the potential to complement track-two bilateral events. For example the Jung Königswinter Conference is a track-three wing running parallel to the track-two Königswinter Conference. The Jung Königswinter Conference incorporates under-30s into the dialogue in order to further understanding of the agenda discussed by the main conference and other political, economic or socio-cultural themes. Since 2007, the AALD has incorporated into every AALD event an under 34's Young Leadership Dialogue, which is organised and run by the Young Leadership Dialogue delegates, in consultation with members of the Advisory Council. ${ }^{96}$ Over time track-three events can develop real gains as a younger generation assumes leadership roles in the high levels of government or influential organisations taking with them their track-three experiences.

\section{Track-One-and-a-Half Diplomacy}

Track-one-and-a-half diplomacy assumes officials are the core participants in the process. It is often used in, but not restricted to, conflict resolution processes. Track-one-and-a-half can be distinguished from other tracks by official sponsorship and attendance. Typically the process involves a majority of officials (who may be retired or out of office). ${ }^{97}$

\footnotetext{
93 Ball et al. "Track 2 Security Dialogue in the Asia-Pacific: Reflections and Future Directions". Ibid, pp. 176 and 185.

94 Ball, Desmond; Milner, Anthony and Taylor, Brendan. "Mapping Track II Institutions in New Zealand, Australia and the Asian Region". An Independent Study Submitted to the Asia New Zealand Foundation. 2005, p. 9.

95 Kraft. "Track Three Diplomacy and Human Rights in Southeast Asia". Ibid.

96 Australian American Leadership Dialogue. "Young Leadership Dialogue". www.aald.org/index/index/page/our_programs/catid/59 (Accessed: 09/11/10).

97 Ball et al. "Track 2 Security Dialogue in the Asia-Pacific: Reflections and Future Directions". Ibid.
} 
Officials in track-one-and-a-half generally participate in an official capacity, and often set the agenda, although the chairs (and in some cases the majority of participants) may be non-governmental actors. The ASEAN-Australia-New Zealand Dialogue is a case of one-and-a-half-track diplomacy. ${ }^{98}$

Track-one-and-a-half diplomacy provides non-official actors with some official authority to participate, negotiate or facilitate on behalf of the state or serving as intermediaries between official and non-official actors. ${ }^{99}$ However, a prime purpose of this type of track is also to "prepare the key stakeholders before and during the official negotiating process by building consensus or support for agreements". ${ }^{100}$ It combines the psychologically focused constituency building element of track-two diplomacy with a great deal of official control and oversight.

\section{Benefits of Unofficial Diplomacy}

Unofficial diplomatic processes are less likely to produce concrete outcomes; rather they have an array of benefits that are intangible and not easily quantified. Therefore ascribing the genesis of anything to a track-two process is difficult. ${ }^{101}$ Simon Upton noted in regard to an idea he presented at the 2007 ANZLF that became the Global Research Alliance on Agricultural Greenhouse Gases: "Few policy proposals have a single source - they are normally bounced around in numerous iterations before they take shape". ${ }^{102}$ Quite often unofficial dialogues are intended to be "idea generators", whereby the unofficial and non-obligatory nature of the process allows the exploration of ideas and reactions through communication and problem-solving exercises. Results, then, are rarely tangible and concrete outcomes, but have instead ideational, social and intangible effects.

As a diplomatic design, ideas that do come from track-two events have the potential to be claimed as political party initiatives rather than being directly attributed to the meetings. Track-two events provide intergovernmental demand with a broad source of innovation and expertise that is difficult to achieve through bureaucracy. They supply new ideas, concepts and inputs from the private sector, which are especially useful for technical

\footnotetext{
98 The ASEAN-Australia-New Zealand Dialogue brings together key diplomats, economists, security analysts and academics.

99 Search for Common Ground Organisation. "Track One and a Half Diplomacy". www.sfcg.org/resources/resources_terms.html (Accessed: 15/01/11).

100 Ibid.

101 Simon Upton. Private correspondence with author. 17 November 2010. Also see: Ball et al. "Mapping

Track II Institutions in New Zealand, Australia and the Asian Region”. Ibid, p. 182.

102 Private correspondence with Upton. Ibid.
} 
and complex processes like creating a single market. Governments can also use track-two events to test policy proposals by observing reactions, so-called trial balloons; and distance themselves from specific ideas that might cause public controversy. Ironically, once major proposals are acted upon, or taken over by governments in formal decision-making circles, there is the potential for informal dialogues to diminish in importance due to success. ${ }^{103}$ Alternatively, if the dialogue is focused on a specific issue and there is no political motivation to take the agenda forward, unofficial diplomatic processes can be disbanded altogether. In cases of track-one-and-a-half, governments are in a position to change arrangements, and in all forms, fora like the ANZLF may be "subject to review".

However, much of this depends on the purpose, structure and substance of the event and its particular process, which determines how the meetings will develop. If the meeting is deemed successful it may create a completely user-pays event in which demand to attend exceeds meeting limits (the Centre for Independent Studies Consilium meetings for instance). ${ }^{104}$ If the "right" people or groups (official or non-official) are present, the potential for all forms of non-official diplomacy to achieve a desired outcome is greatly improved - the biggest variable, however, is whether governments respond or not.

\section{Conclusion}

This chapter has laid out the ground work for understanding the ANZLF from a diplomatic perspective, with the goal of situating the ANZLF, its activities and its participants into a broader theoretical context. There are a number of questions about whether non-state participants in non-official processes constitute transformative agents, or whether these events are merely a diplomatic mechanism with a political strategy, whereby core relationships are strengthened with an impetus to advance a political agenda. The various tracks that encompass contemporary diplomacy tend to highlight the proliferation of non-official actors in transnational governance, yet in the context of the present study, the "autonomy dilemma" raises questions about whether processes like the ANZLF have substantive and independent agendas for change, or whether they only rubber stamp established government policy. In sum, by operating through non-official diplomatic

\footnotetext{
103 Stone and Nesadurai. Ibid.

104 Described as one of the most significant intellectual gatherings in Australia, Consilium is an annual public policy conference held in Coolum, Queensland. It attracts government and non-governmental participants from a variety of backgrounds to discuss a range of contemporary topics, including trade, terrorism, education, and current affairs. Attendees have included former and current ministers: Tony Abbott, Alexander Downer, Craig Emerson, Julia Gillard and Kevin Rudd, and a number of New Zealanders, Don Brash for instance.
} 
channels, does the state remain the pivotal player, or can an institution like the ANZLF acquire a life and influence of its own? 


\section{Chapter Two}

\section{The Genesis of the Australia New Zealand Leadership Forum}

\section{Introduction}

This chapter provides an historical overview of trans-Tasman economic relations, and how the Australia New Zealand Leadership Forum (ANZLF) emerged in 2004. It will show that non-governmental input into trans-Tasman policy initiatives has been a gradual process. In spite of consistent lobbying from the business sector, advances in creating a common market were often blocked by cool ministerial relationships and interests in alternative or competing markets. Far from "globalising", in the 1990s Australia and New Zealand were diverging in their outlooks and policies and not moving forward together. Several events in the early 2000s helped reverse this trend, including a renewed imperative to create a unified market, and the establishment of the Leadership Forum.

In tracing the Forum's genesis this chapter will examine how the idea of a single economic market (SEM) generated interest among a number of ministers in the early part of this century. The combination of heightened trans-Tasman ministerial rapport and a political interest in proceeding with a SEM was accompanied by three other critical elements. These were Asian regionalisation, a number of politically sensitive incidents that produced negative publicity, and a parliamentary select committee report. These factors all added impetus to the idea for a leadership forum and the incorporation of a wider set of stakeholders into the bilateral relationship. However, the primary factor leading to the Forum's establishment was a New Zealand diplomatic initiative that sought to reenergise the bilateral relationship, and by doing so advance New Zealand's economic and political interests.

\section{Historical Overview}

During the 1890s, New Zealand was deeply involved in debates surrounding the structure and nature of the Australian Federation. Issues of common concern to those state-makers were debated, such as migration, defence, transportation, currency, commerce and trade. Ultimately New Zealand declined to become an Australian state, instead retaining control over its own national interests. This was indeed a period of formative international 
economic integration, or "globalisation", when trans-Tasman travel was relatively unrestricted and there was a high degree of economic integration between the colonies. A prime objective of the ANZLF is to recreate that era of open borders, a single market, and the same paperwork.

From being highly integrated economies in the nineteenth century, Australia and New Zealand grew apart economically and for nearly one hundred years they continued to drift in their separate directions. ${ }^{105}$ It is well known that the 1901 Australian Constitution still holds a clause in paragraph six of the preamble that allows for New Zealand participation in that Federation. However, New Zealand believed then that its future economic prospects would be more secure if it looked further abroad. Refrigerated shipping and access to the British market ensured that security, consequently shifting New Zealand's interaction and interests away from Australia and towards the British Isles - a period historian James Belich considers as recolonisation with, not by, Britain. ${ }^{106}$ By 1952, the value of New Zealand exports to Australia had fallen as low as 1.6 percent of that country's total exports. ${ }^{107}$ As one editor put it in 1948: "the spirit of trade, indeed, has been largely at odds with itself, raging uneasily over the turbulent Tasman". ${ }^{108}$

It was not until Britain declared its intention to integrate into the European Economic Community in the 1960s - finally doing so with full membership in 1973 - that Australia and New Zealand were prompted to forge new markets throughout the world beyond those connected to the British Commonwealth. In effect, this gave rise to a renewed emphasis on strengthening bilateral relations between each other, and to initiate greater non-state involvement in trans-Tasman bilateral affairs.

Before the signing of the cumbersome and complicated New Zealand Australia Free Trade Agreement (NAFTA) in 1965, New Zealand manufacturers were persuaded to modify their opposition to the agreement. Industry leaders were brought into an annual quadripartite meeting, the Australia-New Zealand Consultative Committee on Trade (ANZCCT), in 1960 in order to explore possibilities for increased bilateral trade. The

\footnotetext{
105 The trans-Tasman world was marked by hyper-regulation, as both countries protected and insulated their economies from the outside world. Although it would be an overstatement to say that trans-Tasman interactions outside of the economy were totally diminished, on the contrary, the two countries shared interests, ideas, people, and wars. Nonetheless as E.J. Tapp noted in 1951: "In matters of defence the record of events has been different to matters of commerce and trade". Tapp, E.J. "Australia and New Zealand Relations 1900-1950". The Australian Outlook. December 1951, p. 231.

106 Belich, James. Paradise Reforged: a history of New Zealanders from the 1880s to the year 2000 (University of Hawaii Press. Honolulu 2001).

107 Prendergast, John Bernard. "Trade with Australia" in A.H. Lintock (ed.) Encyclopaedia of New Zealand (Wellington 1966).

108 Editorial. N.Z. Southern Cross. 13 February 1948.
} 
ANZCCT was notable, as Philippa Mein Smith points out, because it led to annual trade minister meetings and increased levels of communication and consultation among bureaucratic and diplomatic officials and leaders in the private sector. ${ }^{109}$ Through these meetings, the private sectors of both countries were encouraged to consult with each other in what could be considered a distant predecessor to the current Leadership Forum discussions.

The primary motivation of NAFTA was to secure a market for New Zealand forestry products and Australian cars. ${ }^{110}$ It was cultivated out of a friendship between two future Prime Ministers, Australian John McEwen and New Zealander John Marshall. However, the Agreement was time consuming and failed to produce beneficial results. This was due to both the structure of the Agreement and unresolved domestic concerns, such as vested business interests in the insulated and protected economies. In particular manufacturing sectors in both countries took advantage of the agreement's provision for exceptions. ${ }^{111}$

Australian Deputy Prime Minister Doug Anthony, concerned about New Zealand's economic position requested an end to NAFTA. He renewed his outlook on the trading relationship in order to secure New Zealand's increasingly shaky institutional and financial robustness, thus protecting Australian interests. New Zealand had little option but to comply. ${ }^{12}$ The Agreement on Tariffs and Tariff Preferences was signed in 1977, and the Nareen Declaration in 1978. These agreements promoted closer cooperation and led to the Australia New Zealand Closer Economic Relations Trade Agreement (CER), which came into effect in 1983 after several years of difficult negotiations. ${ }^{113}$ Anthony and New Zealand Minister for Trade Hugh Templeton had a long-term vision that CER would lead to a federation, but plans were disrupted by respective election losses.

CER turned around one hundred years of drifting. In parallel, it set a precedent that opened both countries' economies to a wider and globalising world. Its inward and outward looking design signalled a closer economic relationship, yet in spite of increased and frequent discussions it did not consolidate close and personal political relationships at a senior level. Indeed, leading politicians on either side of the Tasman became more

\footnotetext{
109 See for example: Mein Smith et al. Ibid, p. 313.

110 Holmes, Sir Frank. Policy Paper No 17: The Rocky Road to CER. Institute of Policy Studies. Wellington 2003, pp. 8-10.

111 Nixon, Chris. CER: The Cornerstone of New Zealand's Trade Policy (New Zealand Institute of Economic Research. Wellington 2000), p. 6.

112 Ibid.

113 Holmes. Policy Paper No 17. Ibid.
} 
concerned with the changing international trading architecture - especially in Asia - and less concerned with trans-Tasman prime ministerial rapport, particularly after the ANZUS crisis. In spite of CER's outward looking approach, any cooperation in overseas markets was generally a response to perceived national strategic environments. ${ }^{114}$ Differences in perspectives on, and approaches to, business law, immigration and defence issues, for example, saw the two countries becoming far from streamlined in laws, policies and regulations.

\section{The Australia New Zealand Business Council}

In preparation for CER, the 1978 Nareen Declaration prompted the formation of the Australian New Zealand Businessmen's Council (ANZBC) and the Australia New Zealand Foundation (ANZF). ${ }^{115}$ More formalised than the Consultative Committee, the ANZBC and ANZF were jointly established by Prime Ministerial agreement in order to develop awareness in the context of a bilateral relationship and were effectively the first genuine attempt to broaden the relationship beyond conventional diplomatic and political channels. The ANZF primarily supported projects aimed at strengthening trans-Tasman good will, with a particular emphasis placed on youth exchanges. ${ }^{116}$ The ANZBC was charged with encouraging trans-Tasman trade and investment by articulating business concerns about impediments to trans-Tasman business traffic. The ANZBC's objectives were to represent the interests of companies that trade or conduct commercial activities, including investments, between Australia and New Zealand; and to influence government laws and regulations.

The Council attempted to provide an informed environment for efficient business relations between Australia and New Zealand. Through separate national arms, the ANZBC played a consultative role during the CER negotiations and at CER ministerial review meetings up until the early 2000s, by provision of business sector views alongside

\footnotetext{
114 Ibid.

115 The name was changed in 1988 to a more politically correct Business Council. Information on the ANZBC was sourced from interviews with Hon Jim Sutton, and former Council executives, John Jenner, Dr Ross Patterson, and Peter Shirtcliffe.

116 The ANZF was established to encourage close cooperation between Australia and New Zealand. Its primary remit was to encourage peoples to get to know each other better. The ANZF had separate executive boards on both sides of the Tasman and encouraged study and discussions on issues of importance to Australia and New Zealand; the development of awareness in the context of the bilateral relationship as well as matters of common interest in international affairs. However the ANZF was disbanded in 1998 after the New Zealand Government withdrew its support. The Australian Government responded a year later. Australia Foreign Affairs Review. Canberra. February 1983, p. 60.
} 
monitoring, promoting and lobbying for regulatory changes. ${ }^{117}$ The Council did this by identifying possible solutions for ministers' consideration, and it also raised many of the issues that still remain in the "too hard basket", particularly around taxation and in areas that aroused domestic opposition. In essence the ANZBC lobbied for a trans-Tasman borderless market (the free movement of goods, services, people and investment), but political support only extended as far as election periods.

Despite persistent lobbying, by the turn of the millennium significant obstacles that hindered a free trade area remained, such as business law harmonisation. These operational obstacles resulted in high compliance costs for businesses to operate freely in each other's markets due to different rules and procedures. Harmonisation in specific areas, such as a single market for telecommunications, remained closed, an investment agreement was yet to be reached, and a number of initiatives had been stalled. ${ }^{118}$ In 2000, as a precursor to the ANZLF, the ANZBC argued for the establishment of a Trans-Tasman Advisory Council "comprising leaders from business, government and academia with the responsibility of ensuring relevant policy issues and a borderless market were considered and addressed by 2003". ${ }^{119}$ However, the crucial problem was that until 2002 there were few political leaders willing to champion such a move.

\section{Ministerial Rapport}

Running alongside external events that have changed the course of the trans-Tasman relationship have been varying levels of political interest and rapport. The instigation of greater interaction and cooperation has in the past been periodically championed by the likes of Prime Ministers Joseph Benedict Chifley and Peter Fraser in the 1940s; John McEwen and John Marshall ${ }^{120}$ in the 1960s; Harold Holt and Keith Holyoake (though the relationship between John Gorton and Holyoake was less amicable); and Norman Kirk and Gough Whitlam in the early 1970s. During the late 1970s-early 1980s, New Zealand

\footnotetext{
117 Australia New Zealand Business Council. "Submission Number 12: Australia-New Zealand Business Council Inc. July 2004”. New Zealand Department of Economic Development. Section 64. Review and Schedule 3. Investigation into Unbundling the Local Loop Network and the Fixed Public Data Network. Submission to the Minister of Communications. February 2004.

www.med.govt.nz/templates/Page__2504.aspx (Accessed: 12/12/2010).

118 Australia New Zealand Business Council. "The Future of CER: A trans-Tasman Borderless Market". Joint Submission to Ministers 2000.

119 Ibid. The initial idea came from New Zealand High Commissioner to Australia, Ted Woodfield (1989 to 1994).

120 John Marshall (generally known as Jack) was Deputy Prime Minister in 1957 and from 1960 to 1972, and Prime Minister from 7 February 1972 to 8 December 1972.
} 
Ministers Brian Talboys and Hugh Templeton, and Australian Deputy Prime Minister Doug Anthony were particularly active and engaged. Arguably Robert Muldoon ${ }^{121}$ and Malcolm Fraser contributed to CER, but it is well known that Muldoon and Fraser had little time for each other, and that the relationship was tense and antagonistic despite a shared ideology.

At the public service level, there has been a history of conferences and meetings that have involved a network of consultation and maintained a collegial Australian New Zealand nexus between officials. Yet for CER, which brought the countries closer together in the movement of people, greater movement of money and increased commercial links - high level relationships wavered in the 1980s and 1990s, and did not reflect the forward looking and new economic arrangements invested in the agreement.

Throughout the 1980s and 1990s the relationship was often stalled by a lack of working ministerial relationships and rapport. This was due to differences in defence thinking and emerging trading opportunities elsewhere. ${ }^{122}$ After signing CER, and despite shared ideological allegiances, governments led by Labor's Bob Hawke and Labour's David Lange experienced a strained relationship, primarily because of the ANZUS dispute. Despite some connections, Prime Ministers Jim Bolger and Paul Keating's relationship also suffered from a series of incongruities. The prime example is the Single Aviation Market Agreement that Keating reneged on abruptly not long before its planned implementation in 1994, cultivating some mistrust. ${ }^{123}$ They also abandoned the ANZF by ending financial support for the Foundation. However, Jenny Shipley made major progress on mutual investment with John Howard.

Increasingly the ANZBC found it difficult to get noticed and its ability to influence policy was limited. The lack of government focus and intermittent progress resulted in a declining lack of interest and weight from the Australian side. Involvement in multiple markets and Asia's emergence as a trading and economic force in the 1990s diverted

\footnotetext{
121 Robert Muldoon's role has been disputed. See, for example: Mein Smith, Philippa. "Did Muldoon really 'go too slowly' with CER?” New Zealand Journal of History. Vol. 14. No. 2. 2007, p. 163.

${ }_{122}$ To be sure, some progress was made, such as the Trans-Tasman Mutual Recognition Arrangement (TTMRA) signed in 1996, which aligns CER with the Australian Mutual Recognition Agreement signed by all Australian States in 1993. The TTMRA was reviewed by the Australian Productivity Commission in 2003 which claimed the arrangement was highly beneficial and encouraged all regulators, policy advisors and relevant bodies, to consider the long term benefits of mutual recognition.

123 It was signed in 1996 and a revised 'open skies' agreement was formalised in 2002. For an account see: James, Colin. "Three-Step with Matilda: Trans-Tasman Relations" in Roderic Alley (ed.) New Zealand in World Affairs IV 1990-2005 (Victoria University Press. Wellington 2007), pp. 26-27.
} 
attention away from looking inward, with both governments and business communities increasingly looking northward towards Asia. The essence of the story was that despite friction at the highest political level, and while the overall relationship may not have been substantially moved backwards, it certainly never became any healthier, and consequently the 1990s were, in the words of John Shewan, "a decade of lost opportunities". ${ }^{24}$

\section{Regional and Global Pressures}

Encroaching external pressures have compelled Australia and New Zealand governments to consider more seriously the merits of closer collaboration. Towards the late 1990s, the regionalisation taking place in Asia and the increasing influence that countries such as China and South Korea were obtaining in international affairs contributed to a need for Australia and New Zealand to develop shared solutions and create collaborative approaches to regional issues and the 'globalising' world in general. As Phil Goff argued in 2001: "In a globalising world, it makes sense for two countries, which from an international perspective are both relatively small, to work closely together and continue our efforts to promote our shared interests". ${ }^{125}$ Five years later in an address to the Leadership Forum, Allan Gyngell, David Skilling and Mark Thirlwell suggested that in regard to the Association of Southeast Asian Nations (commonly referred to by its acronym ASEAN) there are important strategic economic interests at stake. They argued the case for Australia and New Zealand conjointly influencing the emerging regional economic arrangements as a necessary preemptive approach to advance those interests. ${ }^{126}$

Despite these sentiments, cooperation often proved challenging. Beyond the South Pacific, and excluding aid delivery, conflict resolution and in multilateral arenas, it had been difficult to work together on a number of fronts due to the competitive nature of the global and regional trade environments. Bilateral relations have been frequently constrained divergences in foreign policies, varying global engagements, and differing national and economic interests. ${ }^{127}$ As a result, the speed and nature of creating joint trade

\footnotetext{
124 John Shewan. Chairperson. PriceWaterhouseCoopers. Interview conducted September 2009.

125 Goff, Phil. "The Trans-Tasman Relationship. A New Zealand Perspective". Australian Review of Public Affairs. Vol. 2. No. 1. 2001. In 2001, Phil Goff argued that Australia and New Zealand are as close as two sovereign countries get, although characterised by a mixture of integration and divergence.

126 Gyngell, Allan; Skilling, David and Thirlwell Mark. "Australia and New Zealand in a Globalising World". Paper presented at the Australia New Zealand Leadership Forum. Sydney 23-24 April 2007, p. 6.

127 See for example: James. "Two countries diverging”. Ibid. True and Devetak. Ibid. Harrigan, and Goldfinch. Ibid, p. 378. Holmes. "Policy Paper No 17”. Ibid.
} 
strategies remained slow and tedious. Relying too long on the "she'll be right" ANZAC tradition, and faith that future Australian leaders will share an historical sentiment, Australian High Commissioner Allan Hawke made it clear on his arrival in 2003 that New Zealand needed to be vigilant and stay on Australia's radar. ${ }^{128}$

Juxtaposed with the pressure of emerging Asian regionalism was the increasing complexity, depth and transformative nature of global markets, and the correlated increases in movement of people, capital, goods and services. ${ }^{129}$ The intensification of global and trans-Tasman traffic meant businesses and individuals made decisions and took actions that crossed national borders and bypassed governmental control. Government officials became unable to stay abreast of all the trading developments, which had outgrown the capacity to be managed efficiently by any one department or agency. ${ }^{130}$ Issues far beyond CER became of significant mutual importance, especially strategic issues facing the region such as climate change, international trade and defence. Therefore, there gradually developed a pressing recognition that the two countries needed to align themselves more strategically in order to maximise their collaborative advantage against regional challenges. Yet in doing so, it was not until the twenty-first century that it was considered beneficial in expanding state capacity by utilising the consul and expertise of business and other actors in a track-two type arena.

\section{Resuscitating the Single Economic Market}

Regionalisation has forced states to consider new political and economic arrangements outside the traditional nation-state framework. Due to these challenges, academics such as Bob Catley have argued that the time is ripe for New Zealand to reconsider a closer union and the supposed mutual benefits of "bigger markets, integrated defence and health

128 The Dominion Post. "Once Were Mates, Now Rivals". 23 September 2003. The Australian High Commissioner Allan Hawke set off a debate about the state of trans-Tasman relations not long after his arrival when he suggested that the relationship was "finely poised on a fulcrum" and could go one way or the other. See: Hawke, Allan. "The High Commissioner". Speech given to the New Zealand Institute of International Affairs. Victoria Law School. Wellington. 12 February 2004.

www.victoria.ac.nz/nziia/assets/talks/wn/Hawke-speech.doc (Accessed: 21/09/10). Hawke's comments were blown out of proportion by the media. Hawke stated later: "I was trying to make the point that as the current generation of Aussies and Kiwis pass on the mantle of leadership, power and influence, to the next generation, the relationship we have taken so much for granted is at risk". Hawke, Allan. "Comparing OZ apples with NZ pears". The New Zealand Herald. 7 December 2005.

129 Gyngell et al. Ibid.

130 The Parliament of the Commonwealth of Australia. Review of Australia - New Zealand Trade and Investment Relations: Coordination and Setting the Agenda. Joint Standing Committee on Foreign Affairs and Trade. Comments from P. Hooton. Assistance Secretary, Pacific Regional and New Zealand Branch. Australian Department of Foreign Affairs and Trade. Canberra. 2006. 
systems... and enhanced Pacific and global influence". ${ }^{131}$ Former New Zealand Deputy Prime Minister, Don McKinnon, believes that in due course New Zealand's inclusion in the Australian Federation is "inevitable", and a number of Australians and New Zealanders appear to support his proposition. ${ }^{132}$ While the prospect of a political union appears unlikely in the foreseeable future, efforts have instead focused on a proposed SEM: a loose economic union as the next stage of CER which has been in the pipeline since 2004.

The SEM concept was not new thinking; it was in fact an original aspiration for the CER agreement. Indeed, Robert Muldoon was aware that a SEM was both "logical and inevitable". ${ }^{133}$ Peter Lloyd argued in 1991 that a single market was inevitable as market forces would unify the two economies and create an "Australasia without a frontier", and the ANZBC had been consistently arguing for a borderless market. ${ }^{134}$ Apart from a failed project between 1992-1995 to harmonise border policies and procedures - which in part stalled due to different approaches to immigration policy - the idea for a SEM was buried until the fifth Labour government came to power in 1999 and there was interest from the Party's right. A number of key ministers played a vital role in resuscitating the SEM project and the bilateral relationship overall. Suddenly CER issues became a priority, taking, as former ANZBC President Ross Patterson claimed, business by surprise. ${ }^{135}$

In spite of some wide differences in policy and strategic approaches to Australian Prime Minister John Howard, Helen Clark's 1999 ascent to leadership slowly reversed the trend of cool prime ministerial relations and began to remedy irritants in the relationship. Yet initially, Clark and Howard, while cordial, were more concerned with signing trade deals with other countries than they were in improving trans-Tasman competitiveness. As Colin James observed in 2003:

"Helen Clark and John Howard have both determinedly fashioned a good relationship. They agree to differ and, thus freed from the negatives, agree on much. Clark helped Howard out with the Tampa refugees. Howard stayed mum on her Iraq anti-war

\footnotetext{
131 Catley, Bob. Waltzing with Matilda. Should New Zealand join Australia? (Dark Horse Publishing. Wellington 2001). Catley was not the only proponent of a political union, for example see: "NZ, Australia should consider merger”. Sydney Morning Herald. 6 December 2006.

132 The 2010 UMR Insight Poll surveyed 1000 New Zealanders and 1000 Australians about the possibility of New Zealand joining Australia as the seventh state. Almost 25 percent of New Zealanders and 37 percent of Australians supported the idea; 71 percent of New Zealanders and 52 percent of Australians opposed it. "Australia and NZ merger 'inevitable"”. The New Zealand Herald. 14 March 2010.

133 Mein Smith. Ibid, p. 163.

134 Lloyd, Peter. The Future of CER: a single economic market for Australia and New Zealand (Victoria University Press. Wellington 1991), pp. 36-40.

135 Ross Patterson, former President of the Australia New Zealand Business Council. Interview conducted September 2010.
} 
statements. Clark won't complain at Australia's go-it-alone on a free trade agreement with the United States, and Howard puts in a word for New Zealand coat-tailing his deal". ${ }^{136}$

The month of August 2000 marked a watershed in elevating the government-business relationship. Following the 2000 CER ministerial meeting, New Zealand Minister for Trade Negotiations Jim Sutton and Australian Trade Minister Mark Vaile invited business leaders to take a greater agenda-setting role at the annual CER Ministers Meeting. They created a "CER Business Dialogue" that ran alongside the formal Ministers Meeting (later to become the CER Ministerial Forum, with the incorporation of Australian Commerce, Fish and Fisheries, Industry and Tourism and Resources Ministers and New Zealand equivalents). Sutton and Vaile commented:

"For the first time in several years our meeting included wide-ranging discussions with the trans-Tasman business community... We welcome this dialogue with business and found direct interaction this morning was valuable to our subsequent discussions. We hope to continue the practice of business involvement at these meetings in future years". ${ }^{137}$

In response, Ross Paterson stated:

"I can't overstate how important this is for the business community. The difference today from what has happened before is that Ministers have in fact invited business to attend the discussions and indicated they want business to drive the agenda". ${ }^{138}$

Sutton and Vaile also set the stage with renewed proposals for closer cooperation on the trade front. Following new prospects for an ASEAN Free Trade Area to be linked up with CER, Sutton and Vaile spearheaded several official joint meetings across Asia. The political process about turned with trade ministers advocating the implementation of CER-related reforms with a desire to pursue joint regional trade initiatives.

In 2002, sector-specific approaches to the dialogue were introduced to engage the

\footnotetext{
136 James, Colin. "Some movement in the glacier". New Zealand Management. October 2003.

137 Joint Ministerial Statement. The Hon. Jim Sutton Minister for Trade Negotiations and Hon. Mark Vaile Minister for Trade. 31 August 2000.

138 Smellie, Pattrick. "Singapore-New Zealand deal a catalyst for wider regional trade agreements". Australian Financial Review. 1 September 2000.
} 
ANZBC and other relevant groups with ministers directly. Vaile provided added Australian emphasis to the trans-Tasman relationship in order to push through long-stalled initiatives. This included a review of country of origin regulations; proposing a new bi-national institution, a Therapeutics Products Authority; and updating the business law harmonisation memorandum. ${ }^{139}$ However, Sutton's and Vaile's enthusiasm to raise CER to a new level was not taken up by other ministers until an announcement was made by the Australian Treasurer and New Zealand Finance Minister to a commitment that would "breathe new air into CER".

While difficult offshore political issues are normally the domain of Foreign Ministries, it was in fact the Treasuries on both sides of the Tasman that instigated the resuscitation of a SEM. The initiative for both a SEM and the ANZLF began in tandem when the CER agreement approached its twentieth anniversary. In February 2003, Australian Deputy Leader and Treasurer Peter Costello and New Zealand Deputy Prime Minister and Finance Minister Michael Cullen committed to advance the CER agenda, and achieve closer economic integration. ${ }^{140}$ In 2004, they formally announced the SEM as a "seamless business environment" whereby "a company of one country would be the equivalent to being a company in the other country" and operate without impediment; a feat Cullen envisaged would be operational within five years. ${ }^{141}$ They jointly introduced a platform for harmonising accounting, banking and competition and security standards as a working framework for a SEM. Cullen and Costello held an informal luncheon with high level business leaders and officially announced the SEM agenda in order to test the proposal. ${ }^{142}$ As Hawke noted at the time:

"[T]he importance of this aspirational announcement has not yet received the attention that it deserves, apart from Fran O'Sullivan and James Weir. I believe that history will look back on this outcome in the same way as CER is now viewed. It's so significant that it deserves a speech in its own right". ${ }^{143}$

139 Ibid

140 Costello, Peter and Cullen, Michael. Joint Press Conference. 19 February 2003.

141 Australian Treasury. "Ministers Enhance the trans-Tasman Business Environment". Joint Press Conference. Melbourne. 30 January 2004.

www.treasurer.gov.au/DisplayDocs.aspx?pageID=\&doc=transcripts/2004/012.htm\&min=phc (Accessed: 14/12/10).

142 Costello, Peter. "Australia and New Zealand: Siblings with a Common Heritage and a Shared Future". Speech by Peter Costello to the Auckland Chamber of Commerce on the occasion of the 20th Anniversary of the Closer Economic Relations Agreement between Australia and New Zealand. 20 February 2003.

143 Hawke. "The High Commissioner". Ibid. 
In March 2004, a Prime Ministerial meeting between Helen Clark and John Howard resulted in the official endorsement of those objectives. ${ }^{144}$ The announcement from the two Deputy Prime Ministers to develop a seamless trans-Tasman business environment based on common regulatory frameworks and reducing compliance costs and other regulatory barriers turned Australian attention back towards New Zealand. Preceding the first ANZLF meeting, Costello warned: "If it [the SEM] is not something that is a high priority, we move on to something else". ${ }^{145}$ The New Zealanders duly took notice of the proactive re-engagement and the SEM idea, which after years of deliberation, took off in its infancy guided by the above comments.

Costello and Cullen set about examining areas for reform. In doing so, an informed and close strategic trans-Tasman relationship between the two governments and trans-Tasman business elite was deemed necessary. Political capital for building on CER was also supplied by Allan Hawke, who pressed upon Costello the importance of taking CER to the next level. ${ }^{146}$ Subsequently, proposals for, and promotion of, a trans-Tasman SEM had been coined "Costello's baby" and were placed on top of the Australian Treasury‘s agenda, alongside Costello’s interest in creating a collaborative approach to regional issues. ${ }^{147}$

Australia's and New Zealand's strategic economic interests were broadly complementary. Costello's interest in enhancing Australian and New Zealand collaboration was seen as a desire to strengthen trans-Tasman trade and investment, particularly in the face of the emerging East Asia region as an economic powerhouse and other regional issues of significance to Australia and New Zealand. ${ }^{148}$ Furthermore, increasing Australian investment in the New Zealand economy, and a concern that New Zealand was a weak link in the security and defence chain, also rekindled Australian interest in the relationship. While Cullen saw closer economic integration as necessary for long-term economic security, Australian authorities viewed significant and increasing Australian investment in the New Zealand economy as a reason to secure Australia's "rear guard".

\footnotetext{
144 New Zealand Ministry of Foreign Affairs and Trade. The Single Economic Market Agenda www.mfat.govt.nz/Foreign-Relations/Australia/2-SEM/index.php (Accessed: 10/04/10).

145 "Trans-Tasman single economic market: What's on the agenda for tomorrow's talks?" The New Zealand Herald. 16 March 2004.

146 Allan Hawke, former Australian High Commissioner to New Zealand. Interview conducted August 2010.

147 O'Sullivan, Fran. "From Beach Barbie to Power Play". The New Zealand Herald. 28 April 2005.

148 Costello. Ibid.
} 


\section{Trans-Tasman Friction}

While the SEM would occupy a large part of future ANZLF meetings, the idea for a Leadership Forum did not come directly from ministerial rapport alone. Nor did it solely eventuate from the desire to build on political agreements to integrate economically, or interest and business group pressure. Rather, a more pressing emphasis came from an exigency for overcoming a perceived deterioration in the relationship, as several events in the early 2000s led to the formation of the ANZLF to advance diplomatic objectives. Although Downer claimed credit for initiating the Forum, stating in May 2004 that "it was an idea of mine two years ago", ${ }^{149}$ it was instead a New Zealand initiative to quell a tumultuous period that caused tensions in certain quarters, leading to an inquiry from the New Zealand Parliamentary Select Committee for Foreign Affairs, Defence and Trade which published their report in 2002. ${ }^{150}$ The report made numerous recommendations for achieving closer links to Australia. One important suggestion was a trans-Tasman forum.

Before Costello's and Cullen's commitment in 2003 to take CER further, there were a number of areas in which the two countries struggled to see eye to eye. Despite Sutton and Vaile's efforts, and renewed Prime Ministerial engagement, the relationship had been marked by peaks and troughs leading to a belief in many quarters that the trans-Tasman relationship had reached a plateau and lost direction. ${ }^{151}$ CER had been useful for integrating certain aspects of trans-Tasman trade and business, but as several critics noted, it had not led to similar policy frameworks in important areas, such as competition, financial investment and taxation. ${ }^{152}$ As Colin James observed: "Until 2003, though there was some progress - notably on mutual recognition of standards and professional

149 O'Sullivan, Fran. "Big neighbour doesn't take NZ for granted”. The New Zealand Herald. 13 May 2004.

150 New Zealand Foreign Affairs, Defence and Trade Committee. "Inquiry into New Zealand's Economic and Trade Relationship with Australia". Ibid.

${ }^{151}$ Jim Sutton, former Minister for Agriculture, and Trade Negotiations. Interview conducted July 2010.

"Bridging the Tasman". The Dominion Post. 12 May 2004.

152 Wells, Nick. "Down-under Vs. world". The Counsel. Chapman Tripp. 18 July 2007. "Closer to Canberra The risk of banking on Australia for a fair deal". New Zealand Management March 2005, pp. 26-33. Skilling, David. "Competing and cooperating: Growing New Zealand's economic relationship with Australia". The New Zealand Institute. 22 March 2007. David Skilling argues a SEM with Australia is "unlikely to substantially strengthen New Zealand's economic relationship with Australia in the manner claimed, just as the rhetoric around the success of the CER agreement runs ahead of the actual outcomes achieved". Skilling notes that Australia's imports from countries other than New Zealand have grown at 9.4 percent annually, while New Zealand's exports to Australia have grown at 8.9 percent a year since 1983, suggesting that New Zealand has lost export market share into Australia since CER was signed. Therefore, Skilling suggests that a SEM will be useful and make some gains yet it does not take the relationship very far in contrast to more compelling strategic possibilities and joint initiatives further a-field in areas where interests converge. The end game, Skilling claimed, is "to grow a strong and successful New Zealand economy not simply to become part of an Australasian economy". 
qualifications (a work still in progress) and air travel - not a lot happened". ${ }^{153}$

Under Clark, the Labour Party had been internally debating the need to take CER to the next level, but had not engaged with Australian officials on the subject. ${ }^{154} \mathrm{New}$ Zealand Finance Minister Michael Cullen noted that CER had for a long time been "frozen around the trade context" and that it had proved difficult to get past tax and investment issues. ${ }^{155}$ On the Australian side, business frustration mounted over behind the border issues involved in harmonising regulatory and business practices, which were frequently stalled. Beyond those issues, there was an impression in Australia that the real gains resided elsewhere. ${ }^{156}$

Antagonistic issues included the delay in harmonising air travel through the creation of a single aviation market. This had been stalled since an attempt between 1992 and 1995 to harmonise border policies and procedures failed to materialise. The defence relationship had also become strained following New Zealand's downgrading of its military apparatus and consequent perceptions on Australia's part of "freeloading". ${ }^{157}$ During 2002 Helen Clark rejected the notion that Australia and New Zealand were a single strategic entity. The invasion of Iraq and concerns over Australia's handling of "the Pacific Solution" were also problematic.

Other issues hung over the relationship, including the longstanding dispute over Australia's barriers that deny market access to New Zealand apples. ${ }^{158}$ Restrictions placed on access to social security for New Zealand citizens in Australia in 2001 were a step forward in terms of removing an irritant in the relationship, but was also seen as a step backwards in terms of integration. In 2001, another dispute broke out over proposed Australian federal legislation to change the way food safety standards would be set by the Australia New Zealand Food Authority (formally, Food Standards Australia and New Zealand) for both countries. The Australian Senate amended legislation that provided the federal Government the power to overrule Food Authority decisions. The perception in some New Zealand quarters was that such regimes effectively reduced New Zealand power

153 James, Colin. "TransTasman deals open door to world". The New Zealand Herald. 13 September 2008.

154 O’Sullivan, Fran. “Treasurers setting the pace” The New Zealand Herald. 2 February 2004.

155 Australian Treasury. Ibid.

156 Urwin, G. "Australia-New Zealand: The Future of the Bilateral Relationship" in Department of Foreign Affairs and Trade Australian Statements on New Zealand. Canberra 1994 cited in Peter Lloyd. "The Future of Trans-Tasman Closer Economic Relations". Agenda. Vol. 2. 1995, pp. 267-280.

157 "No freeloading on Defence, says Goff". The New Zealand Herald. 17 May 2004.

158 For the last 90 years Australia has blocked New Zealand apples from being imported into Australia claiming that the imports would spread a tree disease known as fire-blight. In November 2010, the World Trade Organisation ruled Australia's ban on New Zealand apples is unscientific and breaks the trading rules. 
to that of an Australian state, giving New Zealand one vote out of nine and encroaching on New Zealand's sovereignty. ${ }^{159}$ The legislation was challenged unsuccessfully by domestic opposition in both countries.

Ultimately, it was the failure of Ansett Australia in 2001 that led to a Parliamentary Inquiry. Ansett workers and their unions blockaded Air New Zealand planes at Melbourne and Perth airports, and, alongside Queensland Premier Peter Beattie calling for a boycott of Air New Zealand, the affair took the relationship to a new low. A negative undercurrent in Australian attitudes was directed at New Zealanders. Clark was aboard one such blockaded flight, and Howard had to arrange a VIP flight to get her home. In response to so-called Australian "Kiwi-Bashing” Clark said to Australian media:

"Well, this has been going on for a long time. We get pejorative comment in the Australian media about our economy. Goodness me, the NZ economy has been growing while Australia has been in recession, yet your commentators write us up as a basket case and Australia as some kind of miracle. Please let the facts enter the equation. We get constant bashing about our defence arrangements, yet we are putting in a lot of money for a small country to get first tier highly capable defence forces with work alongside Australia. Now the latest round of bashing, where the whole NZ public is being assailed because of one company's corporate mistakes... Let's just have a bit of calm here". ${ }^{160}$

In 2003, Helen Clark was taken aside at Sydney airport, where she was scanned and frisked for explosives. She claimed in The Age that there would be "an uproar if Australian Prime Minister John Howard had been similarly frisked for explosives by airport security in New Zealand". ${ }^{161}$ Alexander Downer concurred with reports over a troubled relationship, commenting:

"There have been points of disagreement. There was for example the on-going disagreement over defence policy and some broader international issues...Inevitably in Australia we do have different geopolitical perspectives, we have different priorities in foreign policy and security policy. These things do have the potential to drive our two countries apart as time goes on". ${ }^{162}$

159 Kedgley, Sue. “Address in Reply”. The New Zealand Green Party. 3 September 2002.

160 Australian Broadcasting Corporation. “Clark angered by Ansett workers' action”. Insiders. 16 September 2001.

161 "Helen Clark Frisked at Sydney Airport". The Age, 24 November 2003.

162 Ansley, Greg. "NZ and Australia: Standing together, and apart". The New Zealand Herald. 27 March 


\section{Inquiry into New Zealand's Economic and Trade Relationship with Australia}

The New Zealand Parliamentary Select Committee for Foreign Affairs, Defence and Trade released its report in 2002. It elaborated on the successes of CER whilst lamenting the deteriorating trans-Tasman relationship, and concluded that: "there is no substitute for an intensive, disciplined exchange of views". ${ }^{163}$ The report supported the idea of "deepening the relationship at all levels" and claimed that "this may eventually need to lead to new political arrangements". The report acknowledged the importance of New Zealand's relationship with Australia and, therefore, "sought to establish a vision for the long-term future of CER beyond the general cooperation undertaken by both governments and the particular issues of the day". It suggested a "process of economic integration leading to the creation of an Australasian Economic Community" consisting of a single market. The recommendations also included the creation of a cabinet portfolio and think-tanks aimed at rectifying relations; and - most importantly in the context of this present foray into the relationship - initiating an annual forum for political, business and academic leaders modelled on the Königswinter Conferences. These Conferences were established by the British and West German Governments in 1950 to enhance an understanding of the relationship, explore the commonalities and differences, and work towards common approaches in a range of issues and areas.

As with many Select Committee enquiries, the New Zealand Labour Government was lukewarm in picking up the recommendations and leading such an initiative. Labour opposed increased diplomatic and consular representation in Australia or the establishment of a Minister responsible for the relationship with Australia, on the grounds that this would cut into and across the portfolios of other ministers. The Government suggested an economic community was "premature", and claimed there needed to be greater analysis, broader public debate, and an exploration of "other options". ${ }^{164}$ However, they hesitated

2003

163 New Zealand Foreign Affairs, Defence and Trade Committee. "Inquiry into New Zealand's Economic and Trade Relationship with Australia". Ibid, p. 11. Also See: Hempenstall, Peter. "The Australia New Zealand Leadership Forums". Canterbury University. Christchurch 2006. www.nzac.canterbury.ac.nz/docs/leadershipforumsMar07.pdf (Accessed: 27/07/10).

164 "Government Response to the Report of the Foreign Affairs, Defence and Trade Committee into New Zealand's Economic and Trade relations with Australia". Tabled in Parliament on 25 September 2002. Courtesy of the New Zealand Parliamentary Library. Wellington. James, Colin. "Some thoughts on Recent Seminars on the Australia-New Zealand Relationship". Institute of Policy Studies Newsletter. No. 71. November 2002, p. 19. 
over the recommendation for an annual forum. ${ }^{165}$ In response, Frank Holmes stated: "So far, the auguries for a positive outcome are not good. Neither government has given any indication that it wishes to lead such a debate". ${ }^{166}$

\section{The Australian American Leadership Dialogue}

New Zealand's former High Commissioner to Australia, Simon Murdoch, was acutely aware of the pressing issues that were creating a widening chasm in the relationship during the early 2000s. Murdoch argued to the Government that: "[The] relationship with Australia produces too many benefits, it is too important to be entirely left to be managed by the two governments with passive business and community stakeholders". ${ }^{167}$ Appointed Secretary of Foreign Affairs and Trade in 2002, Murdoch was impressed by the Australian American Leadership Dialogue (AALD) as a track-two diplomatic model. Having come back from Canberra where he had seen the value of these regular meetings, particularly in the way they brought new stakeholders into the process, Murdoch believed such an initiative could be a middle ground that could potentially appease a number of interested parties in Australia and New Zealand. ${ }^{168}$

As set out in the previous chapter, track-two meetings such as the AALD align with a body of scholarship that demonstrates the potential of unofficial dialogues to create new relationships and arrangements - where there is sufficient time and the political environment is ripe. ${ }^{169}$ The AALD has been an effective mechanism to keep people who were out of office in touch, which has helped maintain continuity in relationships. Importantly, it was self-sustaining and private sector driven. With an array of academic literature focusing on the divergences in trans-Tasman political relations circuiting in the

\footnotetext{
165 Simon Upton noted: "The Select Committee's proposal for a new cabinet portfolio with a Minister responsible for the Australian relationship gets decisively short shrift in these blunt terms: The relationship with Australia is so comprehensive that it impacts on all Ministerial portfolios. All Ministers are responsible for managing aspects of this relationship. Establishing a new Ministerial portfolio would duplicate responsibilities and risk confusion, particularly on those issues which are primarily domestic but which also have relevance to the Australian relationship. The Cabinet as a whole will continue to have ultimate responsibility for co-ordination and the Minister for Trade Negotiations will retain oversight of the economic and trade relationship with Australia, in consultation with other economic ministers". Upton, Simon. Upton Online Diaspora". 26 October 2002. www.arcadia.co.nz/uptononline/2002/october_26_2002.htm (Accessed: 12/12/10).

166 Holmes, Frank. “An Australia-New Zealand Economic Community?” Institute of Policy Studies Newsletter. No. 71. November 2002, p. 10.

167 Simon Murdoch, former Secretary of New Zealand Ministry of Foreign Affairs and Trade. Interview conducted May 2010.

168 Ibid.

169 Kaye. Ibid, p. 22.
} 
early $2000 \mathrm{~s}^{170}$ and some New Zealand concerns about the potential loss of economic sovereignty, the AALD provided a diplomatically tracked model in which bilateral trans-Tasman relations could be taken to a new level. It also indicated the potential for a shift of responsibility from the government to the business community in creating a form of ownership over an important bilateral event in the political calendar that went beyond politicians, foreign ministries and civil servants. Further, it represented a New Zealand diplomatic opportunity to annually shine an Australian spotlight on New Zealand and build a constituency supportive of the concept of closer economic integration. It was apparent that any attempt to broaden the economic relationship would require renewed business and political support. It fell to Simon Murdoch to persuade the Australian and New Zealand Governments that it was worth advancing. ${ }^{171}$

On the Australian side, Foreign Minister Alexander Downer was receptive. He discussed the issue in depth with New Zealand Foreign Minister Phil Goff, but support from the Prime Ministers was required. John Howard was agreeable; convincing Helen Clark was more difficult. ${ }^{172}$ Murdoch stressed to Clark that after the recent debacles, particularly the Ansett affair, New Zealand had a constituency problem and the available constituency building and rallying tools for trans-Tasman relations had been exhausted (the ANZF was unsupported and had folded in 1998; Australian interest in the ANZBC had waned; and trans-Tasman business communities in general were unhappy about their ability to influence policy). ${ }^{173}$ Helen Clark needed significant convincing: she was wary of business involvement in political affairs and extending too much economic policy space to Australian corporates. Clark, as a backbench MP, had also been a vocal opponent of CER in the early 1980s, opposing the agreement in her maiden speech on 27 April 1982, and opposed the ANZLF's proposals for a common border. ${ }^{174}$ Subsequently and unofficially, the Clark-led government placed a leash on the ANZLF in order to put limits on business interests and values dominating the public policy process. As Fran O'Sullivan stated with respect to Clark's position: "Clark's vision is of a proudly independent nation making its way in the world. She believes a full single market will submerge New Zealand's interests beneath Australia's if the policy changes are not skillfully handled". ${ }^{175}$ Alongside Clark

\footnotetext{
170 Brown. Ibid.

171 Murdoch. Ibid.

172 Ibid.

173 Ibid.

174 Clark, Helen. "Speech to Parliament. 27 April 1982". Hansard. 6 April - 4 May. Vol. 443. 1982, pp. 560-564. O’Sullivan, Fran. “PM makes graffe on border idea”. The New Zealand Herald. 18 May 2004.

175 O'Sullivan, Fran. “Trans-Tasman single market looking likely”. The New Zealand Herald. 26 May 2004.
} 
were also a few government officials and some sections of the New Zealand business community that were equally suspicious of greater Australian involvement in New Zealand's economy. Following the first Forum, O'Sullivan noted that Clark's view was:

“...shared by the small inner core of Wellington's policy elite who pursued a deliberate strategy of their own [at the ANZLF] to stymie a proposal that the powerbrokers endorse a common currency - a proposal they believed would have reduced New Zealand's ability to manage counter-cyclical economic swings". ${ }^{176}$

\section{A Trans-Tasman Forum}

Following both the 2002 Select Committee report, and later through Simon Murdoch's suggestion, Frank Holmes stated that "the response of the New Zealand government to the recommendations indicated that it wanted the lead to be taken by non-governmental organisations", that is, it wanted any initiative to be business-led. ${ }^{177}$ However, as Simon Upton noted: “the Government's response is supportive while leaving almost unlimited room for tactical withdrawal should nothing eventuate". ${ }^{178}$

Downer and Goff had decided by March 2003 that a "leadership discussion group of 40 to 60 piece delegations" would be established to "deepen understanding of each other's viewpoints". ${ }^{179}$ Downer stated that such a group would include opinion leaders from politics, business, media and academia in the hope that a "broadly defined leadership of our two countries can get to understand each other better, understand these difference in perspective, understand why there are differences in perspective, and also look at new ways in which we can work together". ${ }^{180}$

Following a six monthly Foreign Ministers meeting in the Marlborough Sounds in December 2003, the ANZLF became official. Goff and Downer agreed that the relationship between the two countries would be enhanced by bringing together business, political and academic leaders from each country and called on the business community and other interested parties to show interest. However, as Holmes noted:

\footnotetext{
176 Ibid.

177 Holmes. "An Australia-New Zealand Economic Community?”, p. 10. Ibid.

178 Upton, Simon "Upton Online Diaspora". 28 October 2002.

www.scoop.co.nz/stories/HL0210/S00188.htm (Accessed: 18/01/11).

179 Ansley. Ibid.

180 Ibid.
} 
"When this did not appear to be forthcoming, Foreign Affairs Ministers Goff and Downer stepped in and authorised their departments to seek out and cooperate with appropriate business leaders on both sides of the Tasman in order to ascertain who could offer leadership in organising an initial Forum". ${ }^{181}$

Downer and Goff personally selected two key corporate trans-Tasman players, former Fonterra and Fletcher Challenge Director, and then Vice-Chancellor of Auckland University, John Hood and Qantas Chair Margaret Jackson, to co-Chair the first Leadership Forum. However, when Hood was offered the job of Vice-Chancellor at Oxford University in 2004, Bank of New Zealand and the ANZBC Chair, Kerry McDonald, stepped in to become the New Zealand co-Chair. Subsequently, the ANZLF had its inaugural meeting in Wellington on the 14 and 15 of May 2004 with the intention to alternate hosting rights. ${ }^{182}$

There was initial speculation over which business groups would have involvement in making market proposals through the ANZLF. Most non-governmental participants have connections through shared memberships in an array of lobby and business support groups. Nonetheless, as the first Forum would highlight, despite the ANZBC actively supporting the ANZLF, and the New Zealand co-Chair being an active member, the Council was excluded. New Zealand Labour Party Ministers had expressed their wish for lobby groups to be excluded from the process in order not to privilege certain parts of the business community.

The selection of ANZLF participant types, like the AALD, was targeted at individuals, rather than on a group basis. Subsequently, Ross Patterson stated that the ANZBC found itself shut off from being able to push the broader agenda it favoured. ${ }^{183}$ The shift in focus moving away from the ANZBC resulted in its remaining members being faced with a competing organisation with government involvement. Subsequently the ANZBC found itself without a need to make as many submissions or push the agenda, and lost sight of any further value in continuing, and eventually it withered on the vine.

In what can be regarded as an historic initiative, seventy four Australian and New Zealand delegates met at Government House in Wellington. They discussed types of

181 Holmes. "An Australia-New Zealand Economic Community?" Ibid.

182 The inaugural Forum was hosted in Wellington in May 2004, Melbourne in April 2005, Auckland May 2006, Sydney April 2007 and back in Wellington in June 2008, and the sixth meeting was held in Sydney in August 2009 .

183 Patterson. Ibid. 
possible economic arrangements such as a SEM, a trans-Tasman Economic Association or an Australia New Zealand Economic Community, as well as matters pertaining to defence, security, a common currency and border, promoting trans-Tasman integration, and scrutinising regional challenges from Asia and the Pacific. However, the ANZLF's future was far from certain. Peter Costello was adamant that if it did not work he would put his attention elsewhere, such as Singapore. ${ }^{184}$ Therefore before the inaugural meeting in 2004, Kerry McDonald was clear: "we're not going to hang around if it's not working". ${ }^{185}$

\section{Conclusion}

This chapter has provided an overview of the Forum's origins; and above all, it suggested that ministerial rapport and political will has been the most important basis for moving the relationship between Australia and New Zealand forward. The background against which the ANZLF's inception took place highlights that the ANZLF was not the result of business lobbying or trans-Tasman corporate interests as some scholars have suggested. ${ }^{186}$ Rather, the ANZLF was borne out of a New Zealand political desire to strengthen the capacity of its standing in the relationship via expanding CER, in addition to a joint government interest to form a stronger economic grouping in order to influence the changing Asian economic architecture; and a diplomatic motivation to mitigate negative publicity of New Zealand in Australia and build a more supportive constituency. When traditional political tools looked exhausted in the early 2000s, non-official diplomacy was considered an appropriate means by which to advance a number of these political prerogatives.

184 O'Sullivan, Fran. "Too many voices for single market”. The New Zealand Herald, 2 May 2005.

185 "Bridging the Tasman". The Dominion Post. Ibid.

186 Harrigan and Goldfinch. Ibid, p. 376. Despite Harrigan and Goldfinch's claims that the formal impetus for the ANZLF came from a letter penned by McDonald and Jackson, Kerry McDonald claimed no such letter was written prior to the event, and he did not personally know Jackson before Murdoch approached him to co-Chair the Leadership Forum. 


\section{Chapter Three}

\section{The Form and Modalities of the Australia New Zealand Leadership Forum}

\section{Introduction}

This chapter examines the form and modalities of the Australia New Zealand Leadership Forum (ANZLF) as an example of non-official diplomacy. Due to a history of wide and deep people-to-people contact and diversity of informal networks, there has not been a strong history of non-official diplomatic activity across the Tasman. However, considering the significant economic and institutional integration that has already taken place under the Closer Economic Relations Agreement (CER) and the technical work required for a single economic market (SEM), coupled with the global shift towards regionalism - the complexity of the economic tasks at hand have compelled the respective governments to acknowledge that it is to their advantage to work more closely with each other, and to utilise the expertise of non-governmental actors. As a diplomatic initiative to leverage the capabilities of government and non-governmental actors, the ANZLF adds a new dimension to the bilateral relationship. It also demonstrates that as the smaller player in the relationship, New Zealand has to work harder at maintaining Australia's attention. The form and modalities of the ANZLF reflect this dynamic.

The purpose of this chapter is to inform the reader about the diplomatic form of the ANZLF. First, the chapter explains the ANZLF from a New Zealand perspective under the Clark-led Government. Second, details about the various participant types - business, political, unions, academics and political commentators - are surveyed. Third, the role of the co-Chairs is discussed, alongside a number of examples of political interference undermining the ANZLF process. Finally, the ANZLF working groups are outlined, and issues related to funding and the Forum's structure are addressed.

\section{The Role of the New Zealand Labour Government}

The ANZLF is modelled on the Australian American Leadership Dialogue (AALD), and has been widely promoted as an example of track-two diplomacy. The Australian Department of Foreign Affairs and Trade (DFAT) claims that the ANZLF is Australia and 
New Zealand's “main annual bilateral event”, and as such has become an annual institution. ${ }^{187}$ As noted in chapter one, track-two processes should, in theory, maintain a level of independence from official funding, agenda setting and interference. Indeed, the AALD model demonstrates that a track-two forum can maintain a symbolic relationship with the respective foreign ministries, while remaining privately-led and funded. ${ }^{188}$ The ANZLF, however, has struggled to achieve a great measure of independence. As a track-two process a number of those interviewed considered the ANZLF to be a business-led, yet government owned, bilateral event.

Distinctions between tracks two and one-and-a-half are not always as clear-cut in practice as they are in theory. What is certain is that when the New Zealand Labour Government indicated it wanted non-official actors to take the lead in owning the ANZLF, it was intended to be business-led and business-owned and very much a track-two process. Yet when the ANZLF was originally established, it did not have overwhelming political support; rather it had New Zealand political oversight and nurturing by the New Zealand Foreign Ministry.

There is a noticeable gap in governmental commitment to the ANZLF. While the Australian government has approached the forum from a track-two perspective, New Zealand's interactions are closer to track-one-and-a-half. There is the obvious asymmetrical nature of the relationship, where New Zealand as the smaller player must work harder to advance its interests. As such, the New Zealand government kept a keen eye on the Forum and its processes to ensure those interests were maintained. In the Forum's initial stages it was considered by New Zealand Ministry of Foreign Affairs and Trade (MFAT) officials to be a "delicate flower". ${ }^{189}$ A New Zealand official claimed that initially the governments took a cautious approach to the ANZLF, unsure of how it would develop and unfold, and: "whether it was going to get out of control and deliver things they didn't particularly want to hear". ${ }^{190}$

According to some ANZLF participants, the New Zealand Labour Government initially kept its hand on the ANZLF brake. From 2004 to 2008, despite official rhetoric about expanding CER through the ANZLF, the New Zealand Labour Government often paid

\footnotetext{
187 Australian Department of Foreign Affairs and Trade. "New Zealand Country Brief". www.dfat.gov.au/geo/new_zealand/nz_country_brief.html (Accessed: 20/02/11).

188 Australian academic. Interview conducted September 2010. Earl, Greg. "Taking the Diplomat out of Diplomacy". The Australian Financial Review. 18 March 2010.

${ }_{189}$ Australian participant and steering group member. Interview conducted September 2010.

190 New Zealand Government official. Interview conducted September 2010.
} 
lip-service to advancing the ANZLF objectives and the Prime Minister maintained a discrete distance from the event. In the words of former co-Chair Kerry McDonald: "the issue was political...there was a fundamental reluctance on the part of the New Zealand Government through that period to make meaningful change and really engage in the issues". ${ }^{191}$ Another former co-Chair, James Strong, concurred: "we spun our wheels for quite a while... there was a pronounced lack of progress". ${ }^{192}$

Excluding aspects of constituency building and diplomatic expediency to cultivate a greater Australian understanding of New Zealand, the Clark-led government did not want the ANZLF to be overly successful nor heavily resourced. Interviews with New Zealand participants provided a number of rationales for this, for example one participant suggested the Labour Government wanted the ANZLF to be "business owned" so they did not have to fund it and business-led so they did not have responsibility for any controversial aspects that may arise from such dialogue. ${ }^{193}$ In addition, others remarked New Zealand was concerned with the protection of sovereignty and thus avoided ceding any significant decision-making authority to Canberra; and finally there were domestic political considerations where there lacked a broad consensus to move specific issues forward. ${ }^{194}$

Another hypothesis is that the Labour Government attempted through this process to set the pace of economic integration and consolidate its interests and gains in an asymmetrical relationship by allowing time to set its own terms with minimal trade-offs. ${ }^{195}$ For instance, as the smaller partner, New Zealand has an inferior negotiating position to overcome. With fears about Australia's greater wealth and investment capabilities undermining Government efforts to control strategic assets, the 2011 Investment Protocol took over six years to be forged due to Labour Party concerns. As Phil Goff stated, the Labour Government took a cautious approach:

"We were slow for a very good reason: their [Australia's] investment capability means they can buy up assets here very readily... Australian banks already took $\$ 2.5$ billion a year in dividends out of this country". ${ }^{196}$

\footnotetext{
191 Kerry McDonald, former ANZLF co-Chair. Interview conducted May 2010.

192 James Strong, former ANZLF co-Chair. Interview conducted August 2010.

193 New Zealand business participant. Interview conducted June 2010.

194 These views were put forward by a number of Australian and New Zealand business and academic participants.

195 The New Zealand National Government's (2009 to present) attitude to the Forum is discussed in the following chapter.

196 Bedford, Jackie. "Investment Protocol to be Formalised During Gillard Visit". Newsroom. 14 February 2011.
} 
In the longer term, a drawn-out process may serve the interests of New Zealand by regularly maintaining Australia's focus. However, some Australians felt that by treading slowly New Zealand missed an opportunity to take full advantage of Australian attention while it had it under the Howard Government. ${ }^{197}$ With more pressing international engagements and priorities there was an impression from the Australian interviewees that, in general, Australians would like integration to move much faster than it is. There is a perception in New Zealand, however, that trans-Tasman integration generally involves New Zealand adopting Australian standards and structures. As a consequence New Zealand has been unwilling to readily submit to suggestions that limit its sovereign authority and accept the big issues required to create a meaningful SEM, such as a common currency or a "spill-over" of more bi-national institutions.

\section{Maintaining Australian Attention}

Attracting interest from high calibre Australians at both official and non-official levels has always been a persistent challenge for the ANZLF co-Chairs, exacerbated by the lack of progress on a number of issues. In 2005 it was recognised by the co-Chairs that Australian participants, official and non-official, would only remain "engaged and supportive of the process if progress was made on bigger issues - particularly sole prudential regulation of the banking industry". ${ }^{198}$ As such, many Australian business participants, whose time is generally limited and whose companies have more pressing concerns or larger markets to think about, have begun to feel disillusioned and frustrated that the ANZLF's objectives are not moving fast enough - nor is the event receiving enough investment or points on the scorecard. Some business attendees felt that they were invited to take the lead in setting an agenda but instead they have increasingly become passengers in the process. ${ }^{199}$

These scenarios have had a negative bearing on the image of the ANZLF in Australia as a worthwhile, independent, productive and attractive event - potentially jeopardising the constituency building mechanism. There exists, in a number of quarters, a questioning of the value that the ANZLF is adding to the trans-Tasman bilateral

\footnotetext{
197 Australian business executive. Interview conducted August 2010.

198 McDonald, Kerry. "Development of a Single Economic Market and Common Border with Australia". Communiqué 28 July 2005.

199 This was the view of three Australian business leaders, and a number of New Zealand participants interviewed.
} 
relationship by participants and non-participants alike. For example, when asked if there was a bigger expectation at the beginning, an Australian business attendee since 2007 noted: "I did, but particularly seeing the lack of progress over that three-four year period it has just reinforced in me that it's pretty much a waste of time". ${ }^{200}$ When attitudes like this are generated and contributing to attrition, the constituency building mechanism is in question.

\section{The Role of the Foreign Affairs Officials}

The role of the respective Foreign Ministries is one of oversight; they manage the event in the background to ensure a successful meeting. Reflecting New Zealand's nurturing of the event, MFAT have been far more involved than DFAT, and the two Foreign Ministries see themselves providing different roles in the process. ${ }^{201}$ While many annual track-two events have a full or part-time, and often independent, secretariat, in past ANZLF meetings MFAT has played a central role in facilitating the event. DFAT has approached the Forum as very much a business-led Forum and track-two process, and as such it has focused more on facilitating political involvement and meeting arrangements (for example, official bilateral talks that take place in side-rooms during the meetings) and has, in large, left the Australian co-Chair to deal with the nuts and bolts of the organising the event. ${ }^{202}$

For MFAT, the ANZLF has been much more intensive but rewarding. As a strategy for New Zealanders to build strategic relationships with a broad set of important Australian actors, the non-official dialogue intends to bring delegations together on an equal footing. As the following chapter observes, the ANZLF demonstrates that such events can assist a smaller state to address asymmetrical integration and, in part, manage

\footnotetext{
200 Sydney based business executive. Interview conducted August 2010.

201 Australian Department of Foreign Affairs and Trade official. Interview conducted September 2010. Both Foreign Ministries advise on the agenda and prepare joint statements, biographies and briefing papers. They also cover the costs of programmes, and participate in ANZLF meetings as note-takers at the Forum's "break-out" sessions. MFAT performs additional functions, such as acting as pre-meeting sounding boards in advising the New Zealand co-Chair on the current priorities and how to approach a meeting, and coordinating inter-sessional work. New Zealand Ministry of Foreign Affairs and Trade official. Interview conducted August 2009.

202 Some Australian attendees felt DFAT has risked marginalising itself from the event. A DFAT official responded that from a DFAT perspective the ANZLF is very much a track-two event: “...it is business-led and it would need to be run differently [for greater DFAT involvement]... it really comes down to the ANZLF being seen as a business-led event and if they want to change the shape and structure of that and make a stronger role for government, it's something they will have to give thought to. It's not like DFAT have been charged with a greater role... we've never been asked to have a certain role, nor has it been envisaged that we would". Australian Department of Foreign Affairs and Trade official. Interview conducted September 2010 .
} 
the relationship through building both trust and a different type of dialogue that can be difficult to achieve through formal channels.

From a diplomatic perspective, constituency building is a major advantage of soft track-two diplomacy. MFAT claims: "The Forum was established to create in each country a stronger constituency that is well informed about and positively predisposed to the other, and which will encourage and foster the development of a closer relationship between the two countries". ${ }^{203}$ Changing the psychology to "laugh with" rather than "laugh at" was a prime motivation for Simon Murdoch. ${ }^{204}$ From a New Zealand perspective, the ANZLF has afforded New Zealand diplomacy an opportunity to annually draw attention to trans-Tasman issues that constrain New Zealand's position. It advances a diplomatic imperative to partly solve a perennial New Zealand problem: maintaining Australian attention and overcoming the ambivalence and indifference that has characterised relations at an elite level by improvement in the understanding of each other's positions. ${ }^{205}$

This shift is important for New Zealand diplomacy. Indeed, one of New Zealand's greatest risks is that Australians do not think about it. As a result, the ANZLF is a New Zealand attempt to remain front of mind when Australians are making important political and business decisions that have a flow on effect and consequences for New Zealand. The ANZLF has been intended to raise New Zealand's profile and increase support amongst Australia's state and non-state elite in taking the relationship seriously. The ANZLF provides an annual means and focal point to inform and influence an Australian audience to be favourably disposed towards New Zealand initiatives, and not, in the words of Greg Ansley, "submerged beneath Canberra's far broader strategic and economic interests and ambitions". ${ }^{206}$ With regard to the ANZLF, MFAT stated in an annual report:

\footnotetext{
"The impact of attendance at the Forum by large numbers of senior Australian Ministers and business leaders ensures the strategic value of the relationship and its potential for development is registered with and affirmed by both Governments from the outset, laying a platform for future progress on issues". ${ }^{207}$
}

\footnotetext{
203 New Zealand Ministry of Foreign Affairs and Trade. The Australia - New Zealand Closer Economic Relationship (New Zealand Ministry of Foreign Affairs and Trade. Wellington 2005).

204 Murdoch. Ibid.

205 Pre-Forum planning correspondence between Sir Frank Holmes, Simon Murdoch and Kerry McDonald. 3 November 2003.

206 Ansley, Greg. "A united front across the Tasman”. The New Zealand Herald. 12 February 2011.

207 New Zealand Ministry of Foreign Affairs and Trade. Annual Report 2007/08. Wellington 2008.
} 


\section{Participants: General}

For track-two diplomacy to be successful, an event requires the right type of participants and chairs. ANZLF architect Simon Murdoch noted with regard to the ANZLF: "It's got to have a changing cast of the right individuals who have representivity and influence in their sectors on both sides. If it doesn't have that it will run out of gas". ${ }^{208}$ This includes individuals who are considered eminent persons in a position to have an influence on official policy. Highlighting either a bias or the recognition of a relatively small trans-Tasman elite, approximately eighty-five percent of those surveyed for this research indicated that they are generally known to or friends of the respective co-Chairs.

The ANZLF is by invitation only and the composition of participants generally reflects the particular agenda in any given year. Participants are invited to the Forum on the basis of their specialised knowledge, skills and abilities, and other similar attributes which are considered by the co-Chairs to be of value in furthering the trans-Tasman relationship. Most participants come from a variety of different niches, some offer a port and shipping perspective, others come from a tax or labour background. Excluding some academic presenters, all participants donate their own time, pay their own way and accommodation costs (occasional travel sponsorship aside) and volunteer their expertise - and in many cases, utilise their company resources and staff - to the ANZLF process.

The ANZLF is intended to be business-led; therefore approximately half of the Forum participants are trans-Tasman business and corporate leaders. Typical business participants are at chairperson or chief executive level. In spite of it being business-led, the Labour Government initially indicated that the ANZLF should also represent wider community leadership and not simply become a business council, effectively diluting the position of business participants, ${ }^{209}$ therefore a further eighteen percent of the participants have been drawn from academia, unions and the media (see figure one). Unionist representatives have all been national secretaries; academics have ranged from professors to vice-chancellors; and attendees from the media have tended to be trusted, longstanding and respected political commentators. On some occasions sporting and cultural representatives have attended the event. ${ }^{210}$ Out of 527 invitations sent out for the 2004 to

\footnotetext{
208 Murdoch. Ibid.

209 "Government Response to the Report of the Foreign Affairs, Defence and Trade Committee into New Zealand's Economic and Trade Relations with Australia". Ibid.

210 For example, New Zealand Rugby Union Chairperson, Jock Hobbs, attended in 2004, and former Te Papa Chief Executive Seddon Bennington and Prof. Andrea Hull AO from the Victorian College of the Arts
} 
2009 meetings, 258 delegates attended the event; therefore approximately half the ANZLF participants are regular attendees (see Appendix Three). On averager, thirty two percent of the participants are government ministers and MPs along with heads of government departments and agencies.

Figure One: ANZLF Participation by Group 2004-2009

\begin{tabular}{|l|r|r|r|r|r|r|r|r|r|r|r|r|}
\hline & $\mathbf{2 0 0 4}$ & $\mathbf{2 0 0 5}$ & & $\mathbf{2 0 0 6}$ & & $\mathbf{2 0 0 7}$ & & $\mathbf{2 0 0 8}$ & $\mathbf{2 0 0 9}$ & \\
\hline & Aust. & NZ & Aust. & NZ & Aust. & NZ & Aust. & NZ & Aust. & NZ & Aust. & NZ \\
\hline Business & 21 & 17 & 22 & 20 & 20 & 16 & 24 & 18 & 25 & 21 & 24 & 32 \\
\hline Ministers & 2 & 2 & 2 & 2 & 1 & 3 & 4 & 3 & 6 & 4 & 9 & 8 \\
\hline MPs & 1 & 3 & 1 & 2 & 0 & 2 & 2 & 3 & 1 & 4 & 1 & 3 \\
\hline Govt. officials & 6 & 6 & 10 & 9 & 10 & 12 & 10 & 10 & 9 & 11 & 12 & 11 \\
\hline Academics & 3 & 6 & 3 & 3 & 4 & 3 & 6 & 2 & 8 & 1 & 3 & 1 \\
\hline Unionists/Community & 3 & 2 & 4 & 2 & 1 & 1 & 0 & 1 & 0 & 2 & 1 & 1 \\
\hline & & & & & & & & & & & & \\
Pol. Commentators & 1 & 1 & 2 & 2 & 1 & 2 & 1 & 2 & 0 & 5 & 1 & 3 \\
\hline Delegation Total & 37 & 37 & 44 & 40 & 37 & 39 & 47 & 39 & 49 & 48 & 51 & 59 \\
\hline Total Attendance & 74 & & 84 & & 76 & & 86 & & 97 & 110 & \\
\hline
\end{tabular}

\section{A Representative Forum?}

The ANZLF attendees do not represent and have not reflected all influential groups in Australia and New Zealand interested in influencing the agenda. Indeed, a number of participants have lamented that the spectrum of community leadership is not wide enough, thus contributing to a lack of input on social, cultural and educational matters where trans-Tasman relations also converge. ${ }^{211}$ Instead, the ANZLF is composed of mainly European males ${ }^{212}$ and does not attempt to reflect the demographics of the two countries diverse cultural communities, including various diaspora, Koori, Maori, Pasifika, or Torres Strait peoples. Peter Hempenstall, a former ANZLF participant, argued that there is a need to widen the representation at the ANZLF. Hempenstall stated: "They are not representative, parliamentary assemblies, but if they are broadened to include delegates from the fast changing, non-Anglo Celtic communities, the very language of the

\footnotetext{
have represented cultural interests.

211 This was largely the view of academics and unionists, and some business participants.

212 Out of a total of 258 individuals that have attended one meeting or more between 2004 and 2009, 227 have been male, 31 have been female (14 on the Australian delegation and 17 on the New Zealand delegation).
} 
trans-Tasman conversation will change and the cultural mission will come to share more attention with the markets". ${ }^{213}$ Hempenstall and Philippa Mein Smith, in a recommendation to the Australian Joint Standing Committee on Foreign Affairs, Defence and Trade, argued that the widening of the ANZLF's membership by inviting leaders of ethnic and cultural communities, especially those from important emerging markets (namely China and India) would be beneficial to the Forum's objectives. ${ }^{214}$

With regard to wider representation, former New Zealand co-Chair Kerry McDonald claimed, however, there was not a quota system; instead the New Zealand delegation was designed to represent the New Zealand economy. ${ }^{215}$ Most business participants interviewed agreed with the current range of representation. A New Zealand businessman summed up the general ANZLF consensus: "My bias is more towards having the smartest people in the room instead of having a blue one or red etc". ${ }^{216}$ In contrast, others have argued that the ANZLF was designed to discuss broader issues that affect the relationship and that the ANZLF has often resembled a high level business forum to the detriment of wider community leadership and aspirations. ${ }^{217}$ However, a prime purpose of the Forum from a diplomatic perspective was to attract influential Australians, especially those with links to regulators, officials and politicians in Canberra - therefore the Labour Government's original intention for the ANZLF to be more inclusive has steadily given way to a more strategic rationale that aims to attract specific high level Australians from politics and business.

\section{Participants: Business}

With a heavy focus on elites, the ANZLF aims to deliver the top business representatives from both countries. Business representation includes chairpersons and chief executives

\footnotetext{
213 Hempenstall. Ibid. Similarly, the New Zealand Foundation report "Engaging Asia: the role of the Diaspora" argued that the role of diaspora in furthering national interest and international cooperation is an under-utilised mechanism and leaders and policymakers need to be "more attuned to the need to keep diasporas active through appropriate strategic policies". Gamlen, Alan. "Engaging Asia: the role of the Diaspora". Outlook. No. 5. Asia New Zealand Foundation. 2011.

214 Hempenstall, Peter and Mein Smith, Philippa. "Australia's Trade and Investment Relations under the Australia-New Zealand Closer Economic Relations Trade Agreement”. Parliament of Australia, Joint Standing Committee on Foreign Affairs, Defence and Trade. Submission No. 15. 2006.

215 McDonald. Interview. Ibid. More specifically, Kerry McDonald claimed that he was mandated to get together a heavy weight group of people who had an interest in such a gathering, whose business had some relevance to Australian New Zealand relations, directly or indirectly and, excluding community leaders, the delegation had to be broadly representative of New Zealand business.

216 New Zealand business executive. Interview conducted June 2010.

217 New Zealand union delegate. Interview conducted May 2010.
} 
from important and influential companies such as Fletcher Building, Lion Nathan, Qantas, Telstra/TelstraClear, Westpac Bank and a select number of think tanks and business advocacy groups that have gradually become more involved in the event. From an Australian perspective, if executives from the top businesses attend the event, politicians are more likely to show up. However, delivering high profile Australian business leaders has been increasingly difficult for the ANZLF. While Australian business attendees have generally outweighed their New Zealand counterparts in numbers (see figure one), New Zealand's objective of attracting Australians with the strongest political and economic influence has prompted a shift from the initial focus of inviting mainly companies operating in both countries to more recent attempts to attract Australians that have an influence within government or officialdom regardless of whether they have trans-Tasman interests or not.

The inability to influence politicians and officials through the ANZLF reflects one aspect of low Australian business interest in the ANZLF. In theory the ANZLF should provide fertile ground to lobby political participants in attendance and seek benefits for their respective businesses, thus providing an incentive to attend. However, a number of business participants claimed the ANZLF has been ineffective for lobbying and that their companies already have more effective influencing mechanisms and well placed lobbyists in the major centres of decision-making. An Australian business participant said: "I don't see these forms of fora as about having access, but about setting an agenda and getting that agenda executed...[however] there doesn't seem to be a political will to make things happen". ${ }^{218}$ While business participants noted that the meetings have been constructive for creating familiarity with politicians on both sides of the Tasman, several observed that the meetings are short and the agenda tightly packed, making it difficult to capture ministerial attention. Moreover, many of those participants (although some vigorously disagreed) also claimed there was insufficient political and bureaucratic will to carry the ANZLF's ideas forward, an obvious cause for disinterest.

The perception that there is insufficient action from senior politicians and officials to seriously consider and act on ideas that come out of the ANZLF has led to attrition. Instead of business leaders lining up to attend the event, it has been difficult to attract a number of high calibre company heads from Australia. One Australian attendee observed that: "[Certainly] you will find that New Zealand business has generally been stronger in their

218 Australian business executive. Interview conducted August 2010. 
desire to engage and I think Australian business, in general, have been questioning the process". ${ }^{219}$ There are a number of reasons for this. One is that Australian businesses in general are not overly concerned with New Zealand as they concentrate on larger operations in other countries. Another is that failure by the ANZLF to make headway on some important issues has created the impression that the event is nothing but a "talkfest". Indeed, a number of participants lamented that their ideas "fall on deaf ears" and that the Forum has not advanced business interests enough, especially around taxation. As one Australian businessman explained:

"I tend to get the feeling that there doesn't appear to be a significant bureaucratic will to do things. I mean we can talk about taxation harmonisation, particularly around imputation credits and the like, and I mean that's been on the agenda for over a decade now and made no progress at all". ${ }^{220}$

The mutual recognition of the Australian and New Zealand imputation credit systems is one of the greatest issues for business attendees. Alongside withholding taxes, participants have argued that for a SEM to be an effective magnet for attracting capital, goods and people from outside markets, the issue needs be addressed. The major issue surrounding the mutual recognition of imputation credits is the substantial loss of government revenue, a point which has been vigorously defended by the Australian Treasury. In what has been considered a bureaucratic roadblock, the issue has struggled to gain ground on the agenda to the detriment of New Zealanders with shareholdings in Australian companies. Lack of progress on issues such as this, has been a primary cause for attrition.

As explained in chapter two, in spite of wealthy and important companies operating in each other markets, business lobby groups like the Australia New Zealand Business Council (ANZBC) found it challenging to convince ministers to faster advance economic integration. Further, the almost only means to influence policy was through suggestions or presenting their views through submissions. The track-two character of the ANZLF has provided an environment whereby the participants can directly develop a relationship without the formalities of appointments and note takers (aside from the Forum's break-out

219 Australian business executive. Interview conducted August 2010.

220 Ibid. 
groups). ${ }^{221}$ In spite of claims that the ANZLF has been an ineffective mechanism to influence policy, other business participants noted that the meetings have afforded an avenue for direct and informal access to politicians and policy-makers than would otherwise be probable. ${ }^{222}$ In addition to interaction that takes place through the working groups, some participants stated that access to ministers and officials extended from informal conversations at the event to the even more informal dinners and a "beer at the bar" afterwards. ${ }^{223}$

\section{Business Connections}

Underpinning the ANZLF are extensive business connections. Within the trans-Tasman business elite, Shaun Goldfinch has argued that there exists to a large degree shared values and (formal and informal) networks which have contributed to a common business culture. ${ }^{224}$ There is also a great deal of interlocking directorships. For example, one in seven Australian corporations have a director who sits on the board of a New Zealand corporation, while more than half of the New Zealand corporations have directors from Australian corporations. ${ }^{225}$ However, due to the demise of the ANZBC there is no organised trans-Tasman business organisation that specifically aims to lobby business issues.

Track-two processes are aimed at encouraging the effective networking between the business communities and expanding on existing links. The intimate size of populations in both countries, alongside the limited amount of metropolises means there exists a network of largely informal contacts who may know one another from various social networks, club memberships, academic backgrounds, institutions, or conferences. ${ }^{226}$ There are also a high proportion of shared memberships in various domestic organisations or networks such as the Business Council of Australia, Business New Zealand (who have

\footnotetext{
221 Break out groups are several groups that discuss progress and brainstorm on specific issues in-between the plenary sessions. The break-out group nominate a chair to report back to the plenary session. The ANZLF co-Chairs circulate a summary of the discussions - in which the ideas are left with officials to progress, or not. 222 New Zealand business delegate. Interview conducted June 2010.

223 A number of participants mentioned that the informal gatherings before or after the formal meetings were sometimes the most rewarding in terms of relationship building, and for some business delegates it was the only chance they had to talk with politicians without note takers.

224 Goldfinch, Shaun. "Doing Business" in Mein Smith et al. Ibid, Chapter Six. Goldfinch, Shaun. "The Old Boys' Network? Social Ties and Policy Consensus amongst Australian and New Zealand Economic Policy Elites". Policy and Society Vol. 21. No. 2. 2002, pp. 1-25. Harrigan and Goldfinch. Ibid.

225 Goldfinch. "Doing Business" in Mein Smith et al. Ibid, p. 131.

226 Harrigan and Goldfinch. Ibid.
} 
become increasingly more involved in the process since the National Party came to Government), and the Trans-Tasman Business Circle. A large part of the Forum is not only for business leaders to network and discuss how business links can be strengthened, but to also strengthen interpersonal relations between themselves. ${ }^{227}$

Beyond the formal debate and dialogue, a prime, often intangible benefit, of such a forum is the forming of friendships and relationships, and ultimately a greater depth of trust. In this sense the ANZLF has become a real asset in nurturing this development at elite level. Following research in Australia it was notable that the ANZLF has raised the profile of New Zealand, and as such the Australian elite are highly conscious of the importance of the Australia-New Zealand relationship. Half the Australian participants stated that they had, through the ANZLF, made enduring contacts in New Zealand they could call directly. A number of participants provided anecdotal stories that emphasised the value of knowing who people are and the setting up of links between government and business actors that have resulted from the meetings. ${ }^{228}$ Also notable is the cross-sector contacts the ANZLF has created between academia and regulators, unions and business, and media and business, for example.

A major task for the co-Chairs has been to ensure the two delegations come together in a productive and conducive manner. Depending on the issue, the ANZLF's business delegates are generally not one country group seeking to get an advantage over the other, rather the ANZLF has developed into a group of interested parties attempting to achieve common outcomes. Further, business delegates are generally more aligned to where their businesses are domiciled. Therefore the Australian attendee list features Australian company heads which may be New Zealanders, and vice versa. ${ }^{229}$ Some, such as Allan Freeth (TelstraClear), David Kirk (Fairfax Media) Geoff Ricketts (Lion Nathan) and Ann Sherry (Westpac/Carnival Australia), have at one forum or another served on both delegations. In the context of the ANZLF there are some attendees who see themselves less as national players and more a part of a shared trans-Tasman sectoral group.

Notwithstanding, there are others that maintain some nationalistic sentiment and very

227 Dalziel, Lianne. Where To From Here? Launch of the NZAC. New Zealand Government Website. October 10 2008. www.feeds.beehive.govt.nz/speech/where+here+launch+nzac (Accessed: 17/12/10).

228 As one Sydney based participant stated, he would not have meet John Key if he had not been seated next to him at dinner and asked: "So John, what do you?" Interview conducted August 2010.

229 For example, Australians Ralph Waters and Jonathan Ling (Fletcher Challenge), Jenny Fagg (ANZ Bank), Jane Diplock (Securities Commission - although Diplock is a naturalised New Zealander), Ann Sherry (Westpac/Carnival Australia) have been on the New Zealand delegation. Several New Zealanders have served on the Australian delegation: Ralph Norris (Commonwealth Bank), Geoff Ricketts (Lion Nathan), David Kirk (Fairfax) and Scott Perkins (Deutsche Bank), Allan Freeth (TelstraClear) and David Thodey (Telstra). 
much see the ANZLF on a "NZ Inc. or Australia Inc." basis.

To be sure, the early Forums exhibited some overly nationalistic behaviour and there were clearly two delegations. As one academic participant, Peter Hempenstall, noted at the 2004 Forum:

\begin{abstract}
"The familiar worries about the bullying tactics of Australia in any deal with New Zealand soon surfaced as the teams were put together. New Zealand, host of the inaugural Forum at Government House, Wellington, was already on the back foot according to the New Zealand Herald, as McDonald strove desperately to match the Aussies who were organizing key personnel to push a national agenda". 230
\end{abstract}

However, as the ANZLF has progressed into a more collegial setting, it has become more accepted that the business delegates in the two groups have the same interest in seeing through a single market and other aspects of integrating the relationship further, albeit in their respective sectors. A New Zealand businessman in Australia, Ralph Norris, suggested:
"I think it's generally a group of business people [in Australia and New Zealand] and obviously bureaucrats and politicians from both sides of the Tasman - and I think instead of being a formal delegation from each side in a business sense, its really been a case these days that we are a group of business people trying to achieve common outcomes - I don't think it's a case of one group trying to get an advantage over the other". 231

Nonetheless, outside the ANZLF there are two distinct business communities that are not always an entirely united sector when it comes to trans-Tasman integration, or in terms of how they view exporting to each other's markets. A New Zealand Institute of Economic Research report stated that many Australian businesses view New Zealand as a bolt-on, low risk addition to the Australian market, similar to another Australian state, whereby they can generate more sales and diversify portfolios. ${ }^{232}$ On the other hand, many New Zealand businesses view Australia as a stepping stone towards third markets. Furthermore, in the context of the ANZLF, some participants viewed the end game of economic

\footnotetext{
230 Hempenstall. Ibid, p. 2.

231 Ralph Norris, chief executive officer of the Commonwealth Bank Australia. Interview conducted August 2010.

${ }^{232}$ New Zealand Institute of Economic Research. "Stepping towards a borderless market? The future of the trans-Tasman market. Report to the Australian New Zealand Business Council”. New Zealand Institute of Economic Research. Wellington. August 2003.
} 
integration as a unified single market ideally with a single currency and regulators; while other Australian and New Zealand business leaders shared the view that both countries should maintain their independence, own regulations and decision-making capabilities, and only integrate in areas that bring national benefits. ${ }^{233}$

In spite of close links, Nicholas Harrigan and Shaun Goldfinch argue that the characterisation of Australian and New Zealand business communities go beyond a bilateral trading relationship, but not far enough to be considered a transnational community. ${ }^{234}$ Despite a common culture and a desire for greater harmonisation and stronger relationships between the two countries, asymmetric differences and the uneven integration of investment, ownership and trade has led to tension between the two business communities. ${ }^{235}$ In New Zealand particularly, there exists a substantial and influential group of business leaders that remain unconvinced that New Zealand's economic interests closely aligned with that of Australia's will attract more investment capital. One source of discontent has been New Zealand business concerns about New Zealand's economic sovereignty and Australia's corporate dominance. A marked increase in investment during the 2000s has alarmed some business quarters. ${ }^{236}$ There has also been a great deal of concern in New Zealand regarding the "hollowing out", "brain drain" and "Australian lure" of its economy. This has resulted not only in an exodus of educated and skilled workers but also in the relocation of large New Zealand companies, such as Lion Nathan, Fernz, Nufarm and Carter Holt Harvey's paper products division to Australia, and smaller companies being absorbed into Australia businesses.

Interestingly, New Zealand concerns with Australian dominance have also been one reason for New Zealand business participation. Harrigan and Goldfinch state that despite failures to integrate the two stock exchanges or create a sole banking regulator, reservations regarding the loss of control of the New Zealand banking system have paradoxically been a catalyst for New Zealand business leaders pursuing a "deeper and more comprehensive policy dialogue" at the ANZLF level. ${ }^{237}$ The sense of asymmetry and possible threat to New Zealand sovereignty created friction at the first two Forums. As the next chapter will demonstrate, successive meetings have proved to be a critical conduit for resolving some of

\footnotetext{
233 This concurs with a 2009 PriceWaterhouseCoopers Survey. "Reshape Agility for Tomorrow". 13th Annual Global CEO Survey 2009.

234 Harrigan and Goldfinch. Ibid, p. 367.

235 Ibid, p. 371.

236 Those concerns regarded the 52 percent of total foreign direct investment coming into New Zealand from Australia, and Australian controlled companies owning 19 percent of New Zealand assets.

237 Ibid, p. 368.
} 
these problems, by promoting a greater Australian understanding of New Zealand conditions and sentiment.

While the ANZLF has contributed to an expansion of trans-Tasman business connections and a consensus on some issues, there is little evidence to suggest that ANZLF business participants constitute a policy community. Instead, these key domestic business players with often quite different business and policy interests tend to be invited on an ad-hoc or regular basis depending on their relationship with the chairperson and the importance of the respective companies they lead. Notwithstanding, outside the ANZLF individuals such as John Shewan from PriceWaterhouseCoopers and Phil O'Reilly of Business New Zealand are considered influential policy experts in the domestic realm who politicians and officials consult regularly to fill policy gaps. ${ }^{238}$ Nonetheless, whereas the ANZLF is a diplomatic construct, policy communities tend to form organically and be self-organising. The focus remains on the individual participants and, excluding a few entrenched attendees, the participant list is unstable and subject to change. Finally, policy networks operate with a significant degree of autonomy from the state, and it is not clear the ANZLF has had such independence.

\section{Participants: Politicians}

Politician participation is important to a successful event. If business actors are aware that a number of cabinet ministers are in attendance, they are more inclined to participate. Political and bureaucratic participation ranges from deputy leaders, leaders of the Opposition, cabinet ministers to bureaucratic officials such as diplomats (High Commissioners and foreign affairs secretaries), customs officials and regulators. Apart from attending the formal dinners, Prime Ministers have rarely attended the ANZLF as participants, with the 2009 meeting being an exception. However, it is interesting to note that government participation at the ANZLF has since evolved from being bit-players in 2004-05 to becoming the key drivers of the Forum in 2009. A token amount of four cabinet ministers were present in 2004 (Phil Goff, Michael Cullen and Alexander Downer and Daryl Williams), with the number increasing to seventeen in 2009 (see figure one).

In 2005, the ministerial line-up was limited to two Australian ministers (Downer and Peter Costello) and ten government officials compared with two New Zealand

238 New Zealand Listener. “2009 Power \& Influence List: Business \& Economic”. No. 3630 December 2009. 
ministers (Goff and Jim Anderton). Also present were nine New Zealand departmental heads and the High Commissioners from both countries. The Australian Shadow Foreign Affairs Minister, Kevin Rudd, also attended.

At the 2006 Forum in Auckland, Downer was the sole Australian minister present, along with ten bureaucrats. On the other hand, New Zealand had three ministers in attendance (Lianne Dalziel, Goff and Winston Peters) and twelve other participants from various agencies and departments. At the 2007 ANZLF Australian ministers stepped up their participation to include four (Costello, Downer, Malcolm Turnbull and Warren Truss), outweighing their three New Zealand counterparts (Cullen, Dalziel and Peters, and Opposition MPs John Key and Murray McCully were also present). In late 2007, a change of government leadership in Australia stirred a larger governmental presence at the Forum, and political attendance became more pronounced in 2008 .

In 2008, there was a particularly large ministerial attendance on both delegations. The fifth ANZLF in Wellington had six Australian ministers attending including Deputy Leader and acting Prime Minister at the time, Julia Gillard, ${ }^{239}$ and four New Zealand ministers. ${ }^{240}$ The Australian Labor Government sent a strong delegation to Wellington primarily because Rudd had scheduled the 20/20 Summit for the same weekend as the originally planned ANZLF that year, and a marked absence of Australian officials and ministers for a CER $25^{\text {th }}$ Anniversary dinner in Auckland. Sending a high level delegation was seen as an attempt to address these oversights. With Julia Gillard in Wellington, Helen Clark, who had up until 2008 snubbed the ANZLF meetings in Wellington (and as a result John Howard had no choice but to also keep a distance), attended the 2008 Forum dinner.

In 2009, a newly elected National Government in New Zealand matched Australia's Labor Government's commitment to advance economic integration through the ANZLF. The Sydney meeting in 2009 was unprecedented in terms of joint government attendance with eight New Zealand ministers, ${ }^{241}$ therefore requiring the host country to be similarly matched with nine. ${ }^{242}$ Two issues that arise with heightened ministerial attendance is that it sets a precedent and expectation for future meetings to maintain high levels of cabinet level participation and, second, an increasing amount of space has to be

\footnotetext{
239 The delegation also included Ministers Simon Crean, Anthony Albanese, Lindsay Tanner, Nick Sherry and Robert McClelland.

240 Cullen, Goff, Dalziel and Peters, with Opposition members John Key and Murray McCully also in attendance.

241 John Key, Bill English, Gerry Brownlee, Murray McCully, Simon Power, Tim Groser, Wayne Mapp and Steven Joyce.

${ }^{242}$ Kevin Rudd, Wayne Swan, Simon Crean, Stephen Conroy, Penny Wong, John Faulkner, Robert McClelland, Anthony Albanese and Martin Ferguson.
} 
made available for political speeches at the Forums. As a New Zealand business participant claimed: "we need fewer speeches and more debates". ${ }^{243}$ However, the same person also noted that there was little point for business leaders to be debating in a vacuum, therefore political input on issues such as climate change and tax required a political presence. Hugh White (who attended the 2005 ANZLF) suggested that the trick is getting ministers into a debate rather than starting one. ${ }^{244}$

Soft track-two fora work best when people are speaking forthrightly. Therefore a large political presence may restrict or dilute the substance of the dialogue. Although the meetings are conducted under the Chatham House Rule, the presence of domestic adversaries can create a tendency for straight forward boilerplate presentations. On the other hand, politicians may also take advantage of the rule and create controversy to either deviate from another topic or to lift the mood in what might be perceived as a mundane event. Hugh White claimed that the only way for the track-two chemistry between officials and non-officials to succeed is to get politicians to talk very informally, noting that:

"[It is] a mistake to get ministers to introduce that sort of conversation because you just get a routine statement. Objectives in the discussion tend to be very low: they don't want to open up discussions; they want to close them down. They don't want to generate criticism so will say the relationship is fantastic and there are lots of good things happening". 245

Although officials participate in an unofficial capacity in track-two dialogues, the ANZLF also affords an opportunity for ministers to interact with their counterparts on an official basis. Not unlike other international meetings, ministers will walk in and out of the formal sessions and conduct bilateral meetings with their counterparts which might cover alternative issues or aspects of the relationship or international concerns that are not necessarily aligned with the ANZLF agenda. The ANZLF also affords an opportunity for government and opposition politicians to privately talk, as Michael Cullen and then Opposition Leader John Key did over dinner at the 2007 Sydney Forum. Involving opposition members and out of office MPs can be useful to encourage long-term thinking about the relationship, especially if they return to office. Additionally, the Forum provides

\footnotetext{
243 New Zealand business participant. Interview conducted September 2009.

244 White. Interview. Ibid.

245 Ibid.
} 
an introduction for incoming government members to set out their party's policy contexts, priorities and intentions, or the event may inform incoming government views in future policy decisions if they have participated in previous ANZLF dialogues. However, after only six Forums, and four different governments, it is difficult to establish how much of an impact the meetings have had on political participants. An Australian businessman and regular attendee suggested that:

"Clearly the structure is set up that it enables politicians to say "hey this wasn't my idea" or "this was my idea" - in many circumstances what they prefer to say is "look I have had the best advice on this from the Leadership Forum and this is what we are going to do". But they'd prefer in many senses to have that screen and I think that's realistic and makes good politics".246

Ministers encourage officials to have greater and more direct involvement in the ANZLF. The number of officials participating at the ANZLF has doubled since 2004 (see figure one), and on average make-up eighteen percent of the respective participant lists. Many are regular attendees and have been involved in a number of ANZLF working groups. A number of officials have claimed that the ANZLF has contributed to a greater understanding and perspective of their counterparts and broader aspects of the trans-Tasman relationship. Several officials suggested that through the ANZLF's informal environment they have developed a level of trust with their counterparts and with non-government attendees, which has allowed a different conversation to take place between the sectors in Australia and New Zealand. ${ }^{247}$

\section{Participants: Unionists}

Union delegates are not typical of track-two diplomacy; it was, however, a prerequisite from the New Zealand Labour Government that the ANZLF have union representation, a scenario unlikely to have occurred under a National Government. In general, unions have an alternative understanding of economic interdependence to business, and attempt to influence the content of the agenda. Unions have an overarching interest in ensuring that

\footnotetext{
246 Australian business participant. Interview conducted August 2010.

247 Jane Diplock AO, Chairperson, New Zealand Securities Commission. Interview conducted September 2010. Martyn Dunne, Custom Comptroller. New Zealand Custom Services. Interview conducted July 2010. Allan Hawke. Interview. Ibid.
} 
social and employment elements are considered in tandem with issues that arise from trade and productivity.

Unions fitting into the ANZLF have been a cause of frustration for union delegates. One union attendee stated: "I didn't come away with a particularly positive view. I felt that the union presence was largely window-dressing" as labour issues remain in the "too hard basket". ${ }^{248}$ While some overlapping issues like labour flows and migration, relative productivity performances and the drivers of those issues are of great interest to all the ANZLF participants, they take a secondary place on the agenda to what are perceived to be more pressing financial and strategic issues, such as financial regulatory requirements, taxation and a common border.

Nonetheless, interviews demonstrated that union participation at the ANZLF has had a number of benefits. In particular, these benefits include keeping labour issues on the table and educating some chief executives or officials who might not have thought about some issues in a particular way; and placing labour issues in a trans-Tasman context (see Appendix Four for a list of challenges that impede a genuine trans-Tasman labour market). However, as several participants noted, since the first two ANZLF meetings, the substance of its dialogue has increasingly become dominated by the business and political attendees. Reflecting that shift, union representation at the ANZLF has declined from seven percent at the first two meetings to less than two percent in 2009 (see figure one).

\section{Participants: Academic}

In contrast to union participation, academics frequently participate in track-two diplomacy. However, like unionists, academics are invited as specialists in their respective fields, and their representation at the ANZLF is minor. Depending on the year, scholars average around just nine percent of the participant list, with a noticeable decline from twelve percent in 2004 to three and a half percent in 2009. Academics serve a number of purposes conducive to closer integration. Academic participants are influential in their own countries' policy systems, and come from a variety of backgrounds to cover diverse aspects of the relationship, and have ranged from vice-chancellors to security experts. While some have been long-term attendees who pay their own way, others have come on an ad-hoc all-expense paid basis to present perspectives on certain themes. These range

248 New Zealand union representative. Pre-interview correspondence April 2010. 
from history, science and technology, regional perspectives and challenges, security, the environment, the arts and cultural aspects of the relationship.

As with most track-two meetings, academic participation tends to promote a greater freedom to explore alternative perspectives and formulate new ideas. Herman Kraft claimed this is due less to the involvement of intellectuals as "intellectuals" (that is, as providers of expert "objective" analysis), and more to do with track-two diplomacy as a forum where intellectual exchange is intended to be developed alongside interrelationships. ${ }^{249}$ The ANZLF academic participants interviewed had mixed views on their ability to contribute effectively, with some clearly frustrated with the lack of structure or follow up to take ideas forward. However, most agreed that there was an environment that simulated critical contributions, and quality analysis and discussion. ${ }^{250}$

\section{Participants: Media Attendance and Coverage}

In spite of its importance to the bilateral relationship, the ANZLF is virtually unknown to the general public. The ANZLF remains closed to the general media, except for a small number of trusted political commentators (a participant average of just four percent), experts in their own right and known for their insights and knowledge on trans-Tasman affairs. ${ }^{251}$ Their role is informational and important, but it is restricted. Those who are invited to the ANZLF are subject to the Chatham House Rule that constrains reportage in order to encourage openness, debate and the sharing of information within the meeting. David Capie and Paul Evans state that it is typical of track-two dialogues to place an emphasis on "informality, inclusivity, and non-attribution, in order to encourage frank debate and openness by all participants". ${ }^{252}$ Therefore communication between non-state participants and government policymakers and officials is conducted under the Chatham House Rule to provide an open environment to discuss and debate ideas without running the risk of sensationalising a topic in the public domain - particularly with the presence of

\footnotetext{
249 Kraft. "Track Three Diplomacy and Human Rights in Southeast Asia". Ibid, p. 51.

250 This was the view of most academics interviewed, including Prof. Andrea Hull AO, Prof. Allan Fels AO and Sir Frank Holmes.

251 Political commentators from New Zealand have included: Fran O'Sullivan (2007 as an observer and 2005, 2008, 2009 as a participant), Colin James (all Forums - representing the HUGO Group in 2008 and 2009), Brian Fallow (New Zealand Herald Economics Editor, 2006/2008), Brian Edwards (Radio New Zealand, 2008/2009), Tim Parkhurst (The Dominion Post Editor, 2008 and chief executive of the Newspaper Publishers Association 2009); and from Australia: Rowan Callick (Australian Financial Review, the Australian, and Asia Pacific Editor, 2004/2005/2009), and Laurie Oakes (Political Editor, 2006).

252 Capie, David and Evans, Paul. The Asia-Pacific Lexicon. Second Edition (ISEAS Publishing. Singapore 2007), p. 234.
} 
politicians who, in the glare of the public spotlight, might be less willing to contribute to the dialogue and process. ${ }^{253}$

The Chatham House Rule may increase the quality and openness of the dialogue but has stifled the promotion of the meeting as a high profile event, and failed to open the Forum up to the scrutiny of the general media and public. Some participants have suggested that more coverage of these events might be an advantage in raising the profile and thus the prestige of the Forum, but as an official stated, it is felt that, in general, media organisations tend to engage the general public in ways that may not be conducive to the Forum's dialogue. ${ }^{254}$ This is especially the case in relation to issues that involve sovereignty. On the other hand, it is assumed that many of the issues aired at the Forum are unlikely to generate a great deal of interest, for example arcane issues like accounting harmonisation. Nonetheless, in spite of scant overall mainstream media coverage, New Zealand political commentators at the ANZLF, such as Fran O'Sullivan and Colin James, have been vital in providing some insight into the Leadership Forum. To date, coverage and commentary in Australia has been minimal. Promotion of the event, however, is ultimately a matter for the co-Chairs to decide.

\section{Participants: co-Chairs}

The quality, style, experience, flair, enthusiasm and collegiality of a chairperson is integral to any successful track-two event. An ANZLF co-Chair needs to have a high profile, command a great deal of respect, and be influential enough to muster strong contingents and sponsorship for each meeting. ANZLF co-Chairs invest substantial amounts of energy, time, private resources and responsibility whilst running their official affairs. This responsibility places a considerable burden on the co-Chairs, and has in the past affected the quality of the ANZLF meetings.

The fact that non-governmental actors are leading a bilateral discussion is an important one. Once appointed, co-Chairs effectively become an institutional member of a complex system of objectives, rules, preferences, decision-making and authority. ${ }^{255}$ Elevated to perform functions of agenda management, brokerage, and representation that make it more likely for future negotiations to succeed, these individuals should be highly

253 DFAT official. Interview conducted 13 September 2010.

254 Ibid

255 Synder, Richard and Bruck Henry.W. Foreign Policy Decision-Making (Palgrave McMillan. New York 2002), p. 129. 
regarded in their respective fields. ${ }^{256}$ As the interface between the community and government, the ANZLF co-Chairs must play a multilevel and complex balancing act in articulation and appeasement. They are unpaid for the work they do and in large act as the formal secretariats.

Between 2004 and 2010, Australia has had three co-Chairs, while New Zealand has had two. The founding co-Chairs were former Chairperson of Qantas Margaret Jackson, who chaired the first two Australian delegations (2004 and 2005), and Kerry McDonald, then Chairperson of the Bank of New Zealand (and life member of the ANZBC), chaired the New Zealand delegation for the first three Forums (2004 to 2006). James Strong (Chairperson Insurance Australia Group and Woolworths Ltd.) replaced Jackson in 2006, and in turn Rod McGeoch AM (Director of Sky City and CardonShift) took over from Strong in 2008. John Allen (formally NZPost, and currently MFAT Secretary) was selected to replace McDonald in 2007.

The former and current Chairs have all been well placed to guide the proceedings and all have a strong presence in trans-Tasman businesses (John Allen less so before his elevation to MFAT secretary, although he oversaw Datamail's and DHL's Australasian expansion). As the following chapter will demonstrate, different leadership styles have contributed to the Forum shifting from a debate-centred meeting with working groups and distinct national-led delegations towards a collegial setting focused around robust and informative discussions.

The role of the co-Chairs, and particularly the host co-Chair, is to set and guide the agenda for any given meeting. Under the original co-Chairs, there were ten-member steering committees in each country which discussed the range of possible topics (with input from the foreign ministries) and compiled a viable invitation list. As the ANZLF has progressed, formal steering groups have fallen away and the current co-Chairs utilise a less formal and smaller team of advisors to talk through the possibilities of the agenda and invitation list. Yet the track-two structure has on occasion been subject to political interventions, and the co-Chair role has been politicised and exposed to the "autonomy dilemma", where some ideas may not be on the agenda due to official sensitivities or political motivation.

256 Tallberg, Jonas. Power of the Chair: Formal Leadership in International Cooperation (Stockholm University. Stockholm 2008). 


\section{Autonomy?}

In New Zealand it is clear that the definitional boundaries of track-two and track-one-and-a-half diplomacy have been blurred due to political intervention. A number of examples indicated there was a tendency for the Labour Government to pull the ANZLF into track-one-and-a-half by orientating the agenda. Indeed former New Zealand Foreign Minister Winston Peters stated that ministers are in a position to decide what goes on or is left off the agenda. ${ }^{257}$ Although in most cases the agenda has passed approval without a problem, there have been obvious instances of ministerial intervention. For example, Peters ensured, despite opposition from Downer that it should be discussed, that the proposed bi-national Therapeutics Products Authority was not on the ANZLF agenda, ${ }^{258}$ and according to a number of Australian participants Downer made sure the issue of "apples" was also a non-discussable. Additionally, Michael Cullen was under pressure from Costello to keep the issue of imputation credits off the agenda, and Fran O'Sullivan has also questioned why telecommunication regulation was sidelined from the Forum's discussions. ${ }^{259}$

In track-two terms, in order to maintain a measure of political independence governments generally do not make recommendations regarding the composition of attendees. Some participants noted - though it remains unsubstantiated - that at earlier ANZLF meetings, the New Zealand side, being much more politicised, required delegates to be approved by the Government, while the Australian co-Chair has had a freer hand in deciding who will attend, or not. Prior to the 2004 Forum, Margaret Jackson stated:

"All I'd want to say on the delegates is the Australian steering group was free from interference from government in the selection of the group of delegates... We believe the New Zealand group is also free of political interference". ${ }^{260}$

However, at least one incident challenges that assumption. For example, unbeknown to the co-Chair Kerry McDonald, before the 2005 ANZLF meeting a high profile New

\footnotetext{
257 Winston Peters, former New Zealand Minister for Foreign Affairs and Trade. Interview conducted June 2010 .

258 Ibid.

259 O'Sullivan, Fran. "Let's see a real inquiry into the Telecom leak". The New Zealand Herald. 9 May 2006. O'Sullivan said: "In whose interest is it that "self-interested" issues are kept off the agenda for debate at the Australia New Zealand Leadership Forum?"

260 O'Sullivan, Fran. "NZ Inc set up to avert Aussie takeover at summit". The New Zealand Herald. 14 May 2004.
} 
Zealand participant was approached by the heads of three state departments and ministries. They made it clear to that participant that the Government was very sensitive about the ANZLF, and that New Zealand would only make progress if they dealt with some of the smaller issues, rather than the bigger issues the attendee wished to advocate. The participant noted that: "[Their] view was that matters should be taken step by step and the steps were small...the Government officials had got to the stage where there was reluctance to give free and frank advice". ${ }^{261}$ The number of other cases where officials have approached other participants prior to meetings is unclear, however in regard to political involvement in the Forum's composition, in 2006 Michael Cullen did remark on John Key's tentative attendance that: "what is doubtful is whether we invite along any representation from the Opposition". ${ }^{262}$

While close political scrutiny or selection of participants is likely to be on the whole an exception rather than a rule, the selection of the New Zealand co-Chairs has also been political. In New Zealand the co-Chairs have been business leaders selected directly by the Foreign Minister and MFAT. In contrast, the Australian co-Chair role is much less politicised and co-Chairs personally pass the baton on to another participant of choice. The New Zealand Labour Government considered the selection of co-Chairs to be an important political consideration, and as such, extreme care was taken in allocating who had responsibility for the ANZLF.

Also complicating the distinction between track-two and track-one-and-a-half is the case of co-Chair John Allen. In part due to his performance as ANZLF co-Chair, Allen resigned from New Zealand Post in 2009 to take up a diplomatic post as MFAT's first non-public servant to become Chief Executive and Secretary, in addition to co-Chairing the 2009 ANZLF. ${ }^{263}$ With a senior government official determining the agenda, Allen's continuing tenure as co-Chair raised concerns from a quarter of the participants interviewed. Some questioned if the workload placed on Allen while hosting a Leadership Forum was affecting the Forum's potential. On the other hand, others positively noted the benefits of having a co-Chair in such a position to push the agenda. Furthermore, Allen is still regarded as a business leader, even inside MFAT. In order to quell any conflict of

\footnotetext{
261 New Zealand business participant. Interview conducted May 2010.

262 Cullen, Michael. "Parliamentary Debate". Hansard Vol. 630. 6 April 2006, p. 2557. Italics added for emphasis.

263 Fran O'Sullivan claimed that the National Government directed the State Services Commission to appoint someone "who could project 'New Zealand Inc.' on to the world stage and not necessarily a 'chief diplomat"”. According to O'Sullivan, Ministers Murray McCully and Tim Grosser directly guided John Allen's bid for the MFAT role. O’Sullivan, Fran. “Allen appointment a new direction”. The New Zealand Herald. 9 May 2009.
} 
interest, Foreign Minister Murray McCully announced at the 2009 Forum that it would be John Allen's last as co-Chair - although as of early 2011, he has not been replaced. ${ }^{264}$

Political interference has led to a number of co-Chairs stepping down. For example, MFAT encouraged Kerry McDonald to step down after a letter he sent to the Prime Minister indicated a number of steps the ANZLF needed to take in order for the Forum to stay credible. ${ }^{265}$ The letter was not well received, and subsequently John Allen was approved by Winston Peters to replace McDonald. ${ }^{266}$

New Zealand interference and concerns have even stretched across the Tasman. Michael Cullen made his displeasure about first co-Chairs clear: “...as a consequence of last year's forum, significant changes were occurring in the business leadership on both sides of the Tasman”. ${ }^{267}$ Fran O'Sullivan observed that:

“...He [Michael Cullen] didn't say so outright, but his words suggested the decision to replace Qantas chairwoman Margaret Jackson....and the hunt for a replacement for New Zealand forum co-chair Kerry McDonald resulted from their failure to squash criticism in Melbourne and Wellington and their persistent push for policy changes that, at this stage, both ministers consider beyond their ability to deliver". ${ }^{268}$

Subsequently Jackson was replaced by James Strong for the 2006 Forum, and the search for a replacement for McDonald occurred in time for the 2007 ANZLF. ${ }^{269}$ Some participants claimed that the New Zealand Government was clearly nervous about the gung-ho approach by Margaret Jackson constantly challenging the status quo. Instead, the Government wanted the ANZLF to be a consensus-maker - mildly pushing smaller ideas rather than debating the bigger ideas. ${ }^{270}$ Jackson's steadfast approach to the Forum as a

\footnotetext{
264 John Allen claimed: "Mr McCully opened the last forum meeting which I did share [as co-Chair] by announcing it was my last, so I suspect I'm not going to continue to do that". Espiner, Guyon. "Q and A". Television New Zealand. 6 September 2009.

265 McDonald. Interview. Ibid.

266 Peters. Ibid.

267 Cullen. "Parliamentary Debate". Ibid.

268 O'Sullivan, Fran. "Cullen's roars aren’t going to serve him”. The New Zealand Herald. 11 April 2006.

269 Ibid

270 Roderick Deane claimed at the 2005 ANZLF that the big ideas included: "the possibility of a common currency, common third party free-trade agreements, visa-free reciprocal entry, a common immigration policy, more effective labour market regulatory integration, taxation reform between us, and, of course, the major issue of security and defence integration which carries substantial commercial connotations as well. The dilemma is that the big issues look hard to progress but this is where the real gains potentially reside". Deane, Roderick. "Comments on a Single Economic Market for Australia and New Zealand". www.independenteconomics.com/assets/papers/anzleadershipforum.pdf (Accessed: 09/08/10). The authors of CER, had a vision greater than current champions. Recently, Doug Anthony suggested initiatives such as an ANZAC passport, a common central bank (with the European Central Bank as a model), a common currency,
} 
means to push for complete integration by establishing a European-styled economic bloc a Tasman Economic Association - including a common currency, was a much larger leap than the SEM already being contemplated by politicians. ${ }^{271}$ Jackson's insistence on a common currency to be included in a SEM upset a number of New Zealand participants and the New Zealand Government, particularly Helen Clark. A New Zealand business participant lamented the political limitations on the Forum's agenda:

"If the objective is to do small things and some networking then it's fine and probably served its purpose. But I was hoping for higher things that haven't happened". 272

\section{Working Groups}

The ANZLF working groups have been the Forum's drivers, but were not a planned outcome. There are two versions of how the working groups eventuated. One perspective claims the co-Chairs at the first Forum shared the opinion they needed to divide the policy issues up into certain areas and formed working groups. Alternatively, others claim the working groups were formed out of frustration by participants with the first Forum, in spite of the fact they were not scheduled to be formed. There were ten working groups by the end of 2005, tasked with looking at: accounting standards and financial reporting; banking and financial services; common border issues such as rules of origin, mutual recognition arrangements and "behind the scenes" border processes; competition and regulation; demographic and labour markets and productivity research; exploring possible education, research and development initiatives; intellectual property; securities offerings; stock exchanges; and taxation.

The success of the working groups has depended on whether the governments have responded or not. The working groups consist of a mixture of official, business, union, and on occasion non-ANZLF participants ${ }^{273}$ from both sides of the Tasman. In between the

and single stock exchange, and total exemption from foreign investment controls for "genuine investment" from the other country. See: Peart, Mark. "Bridging Trans-Tasman Relationships - Leading the Leadership Movement". New Zealand Management. 1 October. 2008. At his investiture ceremony for the Order of Australia on 16 February 2011, Hugh Templeton implored Julia Gillard to complete "unfinished business", arguing for a customs union, common currency and common border.

271 "Anzacs "close" but could be closer". Television New Zealand. 14 May 2004.

272 New Zealand business participant. Interview conducted May 2010.

273 For example, a sub-working group, the Working Group on Trans-Tasman Competition and Consumer Issues, worked under the auspices of the ANZLF. The competition working group made a submission to 
plenary sessions, working groups break off for discussions and then report back on the key ideas. The ideas are discussed in more detail in a feedback session, and then summed up by the co-Chairs at the end of the meeting. Key issues that come out of the Forum discussions are considered further through the respective working groups and co-Chairs, who take the broad ideas and follow them up after the event. Gradually the work of the groups is presented to governments in the form of submissions and proposals, and to official government inquiries (such as the Henry Tax Review in Australia). ${ }^{274}$ Then, if successful, working group initiatives merge into the public space, such as the planned domestication of trans-Tasman travel that Rudd and Key brought up in 2009, which is a product of previous ANZLF discussions and working group efforts. The working groups that were most successful had government officials chairing them, namely the competition, securities and common border groups. Working groups were most active between 2005 and 2008, and many have since become dormant - a topic that is taken up in more detail in the following chapter.

\section{Funding, Ownership and Administration of the ANZLF}

A final reflection on the form of the ANZLF relates to issues of funding, ownership and administration. A common concern raised by those participants interviewed was that the Forum suffers from a lack of investment and funding which at times has affected the co-Chairs' abilities to operate effectively. The ANZLF is run on a shoestring budget dependent on business and government sponsorship. ${ }^{275}$ Much of the organisational or practical work itself is unpaid, and participants and co-Chairs are often reliant on the use of their company resources and staff.

Under considerable pressure co-Chairs must not only offer leadership and deal with both official and non-official participants but also oversee the logistics and planning of the events and working groups. A quarter of the New Zealanders and over half of the

\footnotetext{
Australian Productivity Commission in 2007 reviewing Australia's consumer policy framework. The working group consisted of one ANZLF participant, Paula Rebstock, and 11 non-participants. For instance, Richard Willcock, Westpac Banking Corporation, Peter Horton, Woolworths Ltd. Debra Blackett, Telecom New Zealand and David Matthews, Fonterra.

274 Allen and McGeoch. Ibid.

275 For example, in 2008 the Forum was sponsored by MFAT, NZPOST, Fletcher Building, Wright, TelstraClear, Westpac, Air New Zealand and Infratil. Banking and trans-Tasman travel are two of the main areas to benefit from a SEM, therefore those industries have been the principal private sector corporate sponsors of the ANZLF. For example, in 2004 the Forum was underwritten by Qantas, ANZ Banking Group and TelstraClear - while in 2009, ANZ Banking Group, the Commonwealth Bank, National Bank of Australia and Westpac Banking indicated they saw the Forum worthwhile by footing the bill.
} 
Australians interviewed suggested that the lack of a secretariat, coordinator or similar administrative unit to assist the co-Chairs and maintain momentum in between meetings was detrimental to the ANZLF. ${ }^{276}$ Arguably it has weakened the ANZLF's potential contribution to the policy-making process. They argue that the ANZLF lacks an exclusive mechanism to take ideas forward, and to monitor and report back on the progress of working groups and governments. As a result, ANZLF participants are often unaware of progress made or otherwise until the following meeting. ${ }^{277}$ This is, as a New Zealand businessman noted:

"...actually the nub of the issue surrounding this event, because actually there is no mechanism for that to happen, and one of the problems I think this Forum has is there is no underpinning structure or architecture that can facilitate that". 278

To be sure, since 2008 the trans-Tasman Business Circle (TTBC) has provided a greater role in assisting the Australian co-Chair in organising the event. While the TTBC's core focus is business networking and it is adept at organising speaking engagements and various events, TTBC staff are not public policy or high strategy experts, nor do they carry much weight with bureaucracies and governmental departments. To complement the TTBC, a number of participants suggested a prominent and well-respected fulltime secretariat could fulfill a number of initiatives that the co-Chairs may struggle with, such as harnessing some of the ideas that come out of the Forum into a concrete discussion paper, preparing position papers or an annual publication, organising people and resources to help on projects and in working groups, and ensuring all the resources, skills and ideas are utilised in a coordinated response. ${ }^{279}$

\footnotetext{
276 Others argued that the Forum should rely on individuals to pick up on issues themselves or through working groups. An Australian businessperson stated: "I think that if you have a great idea and you want something done, you have an obligation to do it yourself, or at least some of it yourself. The realities for all of us involved are we all have resources, so if you have got an issue and you feel it needs follow through, then you need to do the work". Interview conducted August 2010. In contrast another Australian participant claimed: "There's a negative financial impact on you because you are paying your way and using your own resources... someone from a big company may be able to allocate resources but notwithstanding, you also need a mechanism to make something happen...I couldn't direct my office resources to such a programme... and although encouraged by the co-Chairs to set up my own working group, nothing was formalised. I wrote a paper to the co-Chair, but who knows what happened to it... I was trying to understand how it operated... If someone had said to me at the beginning - ok that's a great idea but that's not going to happen - then that would have saved me a lot of energy". Interview conducted August 2010.

277 A participant noted twelve months following the 2009 ANZLF: "A year is a long time between meetings, I haven't heard anything since this last Forum”. Interview conducted August 2010.

278 New Zealand business executive. Interview conducted April 2010.

279 Peter Hempenstall saw the usefulness of the ANZLF to generate ideas. Hempenstall proposed that a Centre at Canterbury University could act as a clearing-house for some of the ideas raised, and issues
} 
Funding presents a paradox. Neither the officials nor non-officials have shown any willingness to fund an administrative unit. From a governmental perspective, some argue that business actors have not been engaged enough and the ANZLF has failed to become self-sustaining. ${ }^{280}$ Unlike its model, the AALD, which developed into an independent and private sector dominated bilateral institution and has minimal direct involvement with the government, the ANZLF has, in the words of an official, "never got there". ${ }^{281}$ Non-official participants have been unwilling to invest a great deal of capital or take full ownership in the ANZLF because there has perceivably been a lack of progress or "wins on the board". The full time chief executive, or semi-retired participants are people who have specific knowledge and experience but with many demands on their time and they tend to prioritise event invitations and only attend ones where they might have the biggest impact. ${ }^{282}$ An Australian businessman noted that "the level of attrition of senior people leaving because of the lack of annual meeting follow through means you don't get the full value out of those people", lamenting that the governments are "spoiling a ship for a ha'pworth of $\operatorname{tar}^{\prime \prime}{ }^{283}$

Confusion over funding and ownership has weakened the Forum's stature and ability to influence policy-making. Funding and resource constraints are common in most non-official diplomatic processes and a key variable in whether objectives are met or not. Ball et al claim:

"A second track process with a steady revenue stream, for instance, is obviously going to find it easier to operate in a more strategic manner, over a sustained period of time. This, in turn, will have a bearing upon its perceived importance and level of influence". ${ }^{284}$

This of course depends on whether an event like the ANZLF is considered simply an

identified, at the Forum meetings. The New Zealand Australia Research Centre was formed in 2008. Additionally, in Scandinavia, Nordic leaders convene an annual track-one-and-a-half "globalisation" forum along with representatives from various sectors of society. The initiative is intended to brainstorm and generate ideas with regard to meeting global challenges. As a basis for the forum, every year a "Globalisation Barometer" report is prepared which provides data on which to base decisions. Ideas that are developed at the forum have a high potential to be translated into concrete projects.

280 New Zealand official. Interview conducted May 2010.

281 Ibid.

282 Australian business participant. Interview conducted August 2010.

283 Ibid.

284 Ball, Desmond; Milner, Anthony and Taylor, Brendan. "Track 2 Diplomacy in Asia: Australian and New Zealand Engagement". Strategic and Defence Studies Centre. The Australian National University. Canberra 2006, p. 19. 
extension of track-one diplomacy, whereby the aims are largely political and not in large a different process; or if it is business-led and owned, and objectives and discussions are intended to be more open and exploratory, and free from political interference. The form of the ANZLF suggests it is a bit of both, therefore officials and non-officials are operating in different strategic directions for, at times, quite different purposes and expectations. This lack of coherency has contributed to a loss of integrity and confidence in the process.

Diplomats, politicians or business actors all have different expectations, and approach the meetings with those in mind. Interviews highlighted that the variety of ANZLF participants have had different expectations of how the Forum should proceed at, and following, the meetings. There also exists a tension over whether the ANZLF is, or should be, an executive body that makes decisions on agenda items which require follow up, or whether it is a body to simply trade views and share ideas. A number of participants noted that there is also a general division in the way participants view both the purpose and the form of the ANZLF. Some participants think it should be an arena to push big ideas, such as a common or shared currency or shared bi-national institutions, which give substance to the idea of a single market, and those that believe most of the problems are practical ones that decisions can be made on. There are also those that have fewer expectations of action-outcomes and are focused on the intangible returns of dialogue in itself.

Indeed, even the Australian and New Zealand Governments view the ANZLF from different perspectives. As this chapter has noted, from an Australian Government and diplomatic perspective the Forum is a track-two event. The Australian delegation has been far less politicised, government funded, and has maintained a level of foreign ministry involvement expected for a track-two process. As a New Zealand initiative, it is not surprising that MFAT have had much more involvement in the Forum than DFAT: second-rate meetings or elite disinterest (or over interest) in the ANZLF are potential liabilities in terms of projecting a positive message about the state of the relationship, therefore the Forum has been nurtured and MFAT have maintained a responsibility to ensure it is widely perceived as successful. What is notable is the Labour Government's interventionist actions into what is intended to be an independent track-two event have given it at times a track-one-and-a-half character in terms of funding, agenda-setting and general autonomy from political intervention. Indeed, the ANZLF highlights that unlike South East Asia countries, for example, where the demarcation between official and 
unofficial in track-two diplomacy is sometimes unclear, ${ }^{285}$ in Australia and New Zealand the lines are clearly marked and distinctive.

\section{Conclusion}

The ANZLF is clearly multidimensional in its form and character, and it does not neatly conform to just one unofficial diplomacy concept. The participants have different roles, backgrounds and perspectives, and some are more actively involved than others. While the participants do not represent all sectors and interests, and while there have been mixed views on the effectiveness of the Forum, the ANZLF remains the only bilateral event that is facilitating active engagement between Australian and New Zealand political and economic elites. Like a policy community, the ANZLF participants may agree on a number of issues, but as union representation demonstrates, they do not all share basic values and principles. Rather, each brings to the meetings both contrasting and complementary perspectives in how they view the trans-Tasman relationship.

However committed the two governments and non-official participants have been in pursuing some of the Forum's goals, they have neglected to invest in the event. One reason for this, other than fiscal constraints, is that the Clark Labour Government was unwilling to let the ANZLF get ahead of the Government's political agenda and economic strategy. The high stakes of getting economic integration with Australia right, and for a least a few weeks either side of the meetings attracting a greater Australian focus on New Zealand, meant the ANZLF was worth closely managing. This echoes Kraft's "autonomy dilemma". The risk is that an event such as the ANZLF gets absorbed into track-one agendas and diverted from the task of advancing broader, less constrained, forward looking discussions and ideas. The Forum's ability to play this role is taken up in the following chapter.

285 See, for example: Stone and Nesadurai. Ibid. 


\section{Chapter Four}

\section{The Australia New Zealand Leadership Forum and trans-Tasman relations $2004-2010$}

\section{Introduction}

This chapter traces the six Australia New Zealand Leadership Forum (ANZLF) meetings that took place between 2004 and 2009 and the events of 2010, when a planned Forum had to be deferred as a result of Julia Gillard's ousting of Prime Minister Kevin Rudd. It surveys some of the main themes and issues that surrounded the dialogues and working groups, and examines the substance and results of those conversations to assess what outcomes have been produced by the ANZLF process. The chapter is in four parts covering the 2004 and 2005 meetings, 2006 and 2007, 2008 and 2009, and the cancellation of the 2010 dialogue. ${ }^{286}$ Specifically, this chapter intends to highlight the maturing of both the ANZLF as an informal institution along with an improvement in the trans-Tasman relationship generally. It argues that while concrete outcomes, especially related to the larger, more substantive, single economic market (SEM) issues have eluded the ANZLF, the meetings have performed a number of critical functions that have contributed to numerous tangible and intangible outcomes - primarily to the benefit of government.

\section{$\underline{\text { 2004-2005 }}$}

\section{Preparations for the Inaugural Forum}

The idea for a bilateral forum attracted considerable attention from the business community. As ANZLF co-Chair Kerry McDonald noted, between 1983 and 2004, two decades passed in which Australia and New Zealand only took small steps towards decisive progress on a closer economic relationship and joint trans-Tasman competitiveness. ${ }^{287}$ As was discussed in chapter two, in 2004 there was a sense of urgency that in many areas the relationship was troubled and divergent, and the ANZLF came to be seen as one way to address the

\footnotetext{
286 It was agreed to alternate the hosting of the leadership meetings. As aforementioned, the inaugural Forum was hosted in Wellington in May 2004, then Melbourne in April 2005, Auckland in May 2006, Sydney in April 2007, and back in Wellington in June 2008. The sixth meeting was held in Sydney in August 2009. The 2010 Forum planned for August in Auckland, however, never eventuated.

287 McDonald. Ibid.
} 
differences by advancing the relationship through assessment, ideas and constituency building. In the lead up to the first event there was a great deal of optimism from business leaders that the ANZLF presented an opportunity for the previously passive stakeholders to transform the trans-Tasman economic landscape.

For the inaugural Forum, the co-Chairs and respective steering groups were charged with putting together a participant list in consultation with the respective foreign ministers and ministries. The multi-sectorial make-up of participants was mandated to represent the various sectors of the trans-Tasman economy and broader relationships, and to bring in a good range of expertise across various fields. To avoid the event becoming submerged by business interests, Prime Minister Helen Clark was adamant that the ANZLF be inclusive of a wide spectrum of society, but there was the constraint that the co-Chairs had to keep numbers at a manageable level. ${ }^{288}$ Seventy-four delegates were present at the first Forum, a number considered by pre-Forum planners manageable to discuss practical and wide-ranging matters that affect the trans-Tasman relationship. ${ }^{289}$ An Australian steering group member observed that unlike the Australian participant list, the New Zealand delegation had rules about who should attend and who should not, stating "the New Zealand attendance was amazingly patchy - obvious people we knew that should have been there, we thought - why aren't they there?"290

The idea of an ANZLF initially aroused a great deal of interest and intrigue in New Zealand. There was a flurry of speculation over who would be selected, and disappointment in Wellington and Auckland from those not invited. The invitations were, in Fran O'Sullivan's words: "a touchy topic among a few bruised egos not on the 'A' list". ${ }^{291}$ In spite of some lobbying by interested parties and certain individuals, co-Chairs Margaret Jackson and Kerry McDonald affirmed the Forum would be bipartisan.

In the lead up to the event, it became clear to the New Zealanders that Australia was setting the terms of engagement. Once Jackson sent her list of Australian attendees to McDonald, there was pressure on New Zealand to refine the New Zealand participants list

\footnotetext{
288 Originally, thirty participants on each delegation were considered an ideal number in order to keep the Forum intimate. Instead, however, the delegation size has sharply increased with each meeting from 74 attendees in 2004 to 110 in 2009 (see figure one). Some regular participants felt that the increase in numbers detrimentally affected the energy and prestige of the event. Also see: O'Sullivan, Fran. "New chance for ones who missed out”. The New Zealand Herald. 26 May 2004.

289 Pre-Forum planning correspondence between Frank Holmes, Simon Murdoch and Kerry McDonald. 3 November 2003.

290 Australian business participant. Interview conducted September 2010.

291 National's then Deputy Finance spokesperson John Key stated: I'm still waiting. It's a bit like when I was 18 and dating - I didn't get a lot of phone calls either'. He did not get the call until 2006. O'Sullivan, Fran. "Guest list a touchy topic at Leadership Forum". The New Zealand Herald. 26 April 2004.
} 
in order to match the strength of the proposed Australian delegation. As Fran O'Sullivan noted at the time: "It is clear New Zealand was caught back-footed by the resources Ms Jackson has marshalled to ensure a strong debate starts on the real issues underpinning all the political rhetoric about a trans-Tasman single market". ${ }^{292}$ Nonetheless, despite considerable hype the ANZLF only attracted a token amount of senior politicians. ${ }^{293}$ In part this was because Jackson had set the tone before the inaugural meeting by calling for a transformative agenda that included a common currency and a single competition regime. She proclaimed that: "We need one process and one umpire". ${ }^{294}$

\section{Changing National Attitudes}

The first ANZLF meeting in Wellington came together with the New Zealand and Australian delegations having markedly different expectations. Frank Holmes suggested that initially there was more enthusiasm from the Australian contingent to get into discussions promoting integration. ${ }^{295}$ Fran O'Sullivan observed that New Zealand participants were initially focused on issues of culture and identity, while the Australian delegates had a clear mandate to make progress on single market issues and to produce some tangible outcomes. ${ }^{296}$ A telling summary regarding the limitations of the first Forum and the general division in views was presented by one participant who stated that there were those that felt complete integration was the Forum's objective on the one hand, and those who merely wanted "a little harmonisation" on the other. ${ }^{297}$

The first and second ANZLF dialogues were thus significant in beginning the task of overcoming nationalistic concerns at the elite level. At both Forums, presenters provided an analysis on the present state of the relationship and the possibilities for the ANZLF to adopt and project a vision as to the future of the trans-Tasman relationship. The co-Chairs led a discussion on the varied perceptions of how the two countries interact and perceived

292 O'Sullivan. "NZ Inc set up to avert Aussie takeover at summit". Ibid.

293 A sense of urgency that New Zealand was missing out on a large trade deal was added as the inaugural Forum coincided with the Australian and United States signing of a free-trade agreement, and only two Australian Ministers, Alexander Downer and Daryl Williams, were in attendance alongside two New Zealand Ministers, Michael Cullen and Phil Goff.

294 Jackson, Margaret. “Address by Margaret Jackson to the Trans-Tasman Business Circle”. 12 May 2004.

295 Holmes, Frank. "The Australia New Zealand Leadership Forum. Reflections on its Proceedings". 17 August 2004. www.ips.ac.nz/events/downloads/Leadership-Forum.doc (Accessed: 16/12/10).

296 O'Sullivan. "Too many voices for single market”. Ibid.

297 Hempenstall. Ibid. 
each other. ${ }^{298}$ Australian High Commissioner Allan Hawke felt that the first dialogue revealed a sense of New Zealanders feeling taken for granted, ignored or patronised by their Australian neighbours. ${ }^{299}$

In the New Zealand camp there was an impression that the Australians were pushing a national agenda focused on an Australian-dominated single market. According to some Australian participants, however, they (the Australian delegates) came to do business and in their minds a SEM meant single regimes in banking, competition, securities, one stock exchange and one currency, and they were willing to use whatever country's system was more efficient. ${ }^{300}$ As a result of this confusion, some Australian participants felt that an anti-Australian sentiment existed at the first two meetings. As one Australian attendee claimed, the Australians felt that the New Zealand delegation was clearly wary of an Australian ambush and remained on the defensive, especially with regard to establishing single bi-national regimes for commerce and banking. ${ }^{301}$ According to a number of participants the prospect of New Zealand adopting the Australian currency also created intense discussions and strongly divergent views (especially at the second meeting in Melbourne 2005). ${ }^{302}$

Banking cast a major shadow over the first two events. In relation to the banking regulation issue (and what has been perceived by many as Australian Government-backed banks pushing for a single regulator), Peter Costello made it clear at the second meeting in Melbourne that in his mind a SEM was to be on Australian terms. As the Governor of the Reserve Bank, Alan Bollard, noted, the atmosphere was tense:

“The Australian political race to succeed John Howard was in full swing and it had been a rugged couple of days in Australian politics. When Peter Costello addressed the New Zealand-Australian meeting he was not in a mood to be trifled with. At the rostrum he cast aside his prepared speech and spoke off the cuff. In essence he said, 'you guys in New Zealand have to get real. If you want to be part of a single economic market with us you can forget having your own banking system. Remember you sold

\footnotetext{
298 Holmes. "The Australia New Zealand Leadership Forum. Reflections on its Proceedings". Ibid.

299 Watkins, Tracy. "Envoy takes dig at Kiwi attitudes" The Dominion Post, 28 August 2004.

300 According to Kerry McDonald, one Australian participant stated at the 2005 meeting: "Our objective is to not impose Australian regulation policy on New Zealand, but to find the best form of regulatory policy". McDonald stated that the statement resonated with the New Zealanders and set the tone for subsequent meetings. McDonald. Interview. Ibid.

301 Australian academic participant. Interview conducted August 2010.

302 New Zealand business participant. Interview conducted September 2009. Australian academic. Interview conducted August 2010.
} 
your banks to us: you don't own your financial system any more. Leave regulation to us. He didn't beat around the bush". ${ }^{303}$

In spite of pressing Australia for years to advance Closer Economic Relations (CER), New Zealanders, in general, were clearly not ready despite rhetoric that the Government wanted to pursue such a project. Suspicious and sceptical attitudes arose that were similar to manufacturers' opposition before New Zealand signed up to NAFTA in 1965 and CER in 1983. ${ }^{304}$ At the first Forum, Australians were reminded that any hint of criticism directed at a New Zealander would be countered by sensitivities with one official remarking: "I don't want to be told about our shortcomings by Australians". ${ }^{305}$ Allan Hawke summed up the general atmosphere: "The Australian side was keen to get some concrete outcomes, whereas the Kiwi side was more inclined to foreplay". ${ }^{306}$

At this time also there was a sense of public resentment towards foreign investment evident in both counties, though particularly New Zealand. When the Labour Government expressed an interest to conclude an investment protocol, Michael Cullen had to tread carefully as foreign investment had become a sensitive topic since the Labour Government prevented a forty percent stake in Auckland Airport going offshore. While New Zealand investment in Australia goes largely unnoticed, New Zealanders have been very attentive to Australia's growing economic ownership and influence. In addition, failed initiatives like the proposed ASX and NZX merger in 2000, the trans-Tasman Therapeutics Products Authority (TTTPA) in $2007,{ }^{307}$ and a failure to create a sole prudential banking regulator have highlighted strong domestic support for decision-making remaining in New Zealand's hands.

The TTTPA, for instance, demonstrated that opposition to certain initiatives can arise and stifle trans-Tasman integration objectives. Strong resistance to the TTTPA

\footnotetext{
303 Bollard, Alan and Gaitanos, Sarah. Crisis: One Central Bank Governor and the Global Financial Collapse Crisis (Auckland University Press. Auckland 2010), p. 26.

304 Sir Frank Holmes. Emeritus Professor, Victoria Institute of Policy Studies. Interview conducted June 2010.

305 Hawke, Allan. "Neighbours, friends and all too often rivals". Address to the New Zealand Institute of International Affairs. Wellington. The New Zealand Herald. 8 December 2005.

306 Ibid.

307 On 16 July 2007, the New Zealand State Services Minister Annette King announced that: "The Government is not proceeding at this stage with legislation that would have enabled the establishment of a joint agency with Australia to regulate therapeutic products". King further advised that "The [New Zealand] Government does not have the numbers in Parliament to put in place a sensible, acceptable compromise that would satisfy all parties at this time. The Australian Government has been informed of the situation and agrees that suspending negotiations on the joint authority is a sensible course of action". King, Annette. "Therapeutics Products and Medicines Bill on hold". Press Release. 16 July 2007.
} 
suggested that without wide ranging consultation and debate, initiatives that affect New Zealand sovereignty and control over decision-making will not slip past the public unnoticed. The TTTPA was portrayed by the Green Party as an authority set up under Australian law to serve Australian interests and, along with the National Party, opposed it. ${ }^{308}$ As such, the New Zealand Labour-led Government and the Reserve Bank proceeded cautiously by placing barriers on banking prudential supervision being eroded from government control and transferred to a trans-Tasman authority.

Additionally, there have been repeated concerns raised by interest groups in New Zealand worried about successful New Zealand businesses relocating their operations to Australia to be closer to markets, or to benefit from Australian government incentives. The Campaign Against Foreign Control of Aotearoa (CAFCA) which counts politicians and some senior business leaders among its membership, made a submission to the New Zealand Foreign Affairs, Defence and Trade Select Committee Inquiry into New Zealand's Economic and Trade Relationship with Australia, where it stated:

"It is also the effective outcome of a takeover, even if a New Zealand branch office remains. The practical effects, on top of the loss of control and influence, include loss of professional skills and high-level employment opportunities to New Zealand, and reduced demand for office space and support services such as legal and accounting...It is difficult to imagine that New Zealand and New Zealanders will figure as highly in the priorities of a Sydney-based executive". ${ }^{309}$

CAFCA claimed in its submission that CER and the closeness of open trade and investment relationships with Australia have led to substantial job losses. ${ }^{310}$ New Zealand companies moving to Australia and Australian companies moving in to control large

\footnotetext{
308 Kedgley. Ibid. Although less so, Australian domestic politics has also had the potential to jeopardise ANZLF objectives. For example, the Australian Liberal Party suggested during the 2010 Australian Federal election that New Zealanders might lose the right to work in, and travel freely to, Australia. See for example: Schouten, Hank. "CER pioneer attacks talk of curbing migration”. The Dominion Post. 27 July 2010. Different perspectives on climate change initiatives is another example where attempts at aligning policies have failed due to domestic party politics.

309 Campaign Against Foreign Control of Aotearoa."Inquiry into New Zealand's Economic and Trade Relationship with Australia. Foreign Affairs, Defence and Trade Select Committee. Submission from the Campaign Against Foreign Control of Aotearoa". 6 July 2000. www.canterbury.cyberplace.org.nz/community/CAFCA/publications/Trade/CERsubmission.pdf (Accessed: 10/01/11).

310 Ibid. Some examples cited by the CAFCA include the Unilever purchase of Helene Curtis which led to the closure of its Christchurch cosmetics manufacturing operations in favour of existing plants in Australia, leading to the loss of 118 jobs; and Heinz-Wattie purchased the assets and brands of Auckland meat processor, Shortland Cannery, then relocated operations to New South Wales.
} 
segments of the New Zealand economy were a concern shared with some other quarters of New Zealand society. The New Zealand Green Party raised concerns that the excessive trade deficit New Zealand had with Australia (NZ\$802 million for the year to December 2002), and the prospect of a SEM with Australia, including a common currency and the merger of the Australia New Zealand stock exchanges, was a step toward de facto political integration - without a wide ranging public debate over what New Zealand's vision of a long term relationship with Australia should be. ${ }^{311}$

New Zealand politicians, bureaucrats and domestic lobby groups have certainly taken issue with the substantial amount of Australian bank ownership, often for political point scoring. Commonwealth Bank Chief Executive and ANZLF participant Ralph Norris implicates the fundamental notion of sovereignty into the issue:

"I would say it is an issue of sovereignty, and a degree of suspicion of Australian banks. Particularly when you look at the way Australian banks have been treated by New Zealand politicians over the past few years. I don't think they have made Australian banks feel particularly welcome. The rules have tended to change on taxation rulings. We have seen situations where levies have been applied on Australian banks... and New Zealand institutions have largely been exempted from that, and I would say that Australian banks in general don't feel particularly enamoured by New Zealand politicians and bureaucrats". ${ }^{312}$

The criticism of Australian-owned banks in New Zealand has drawn attention to a strand of economic nationalism. ${ }^{313}$ The first two Forums thus began the difficult task of ironing out a number of issues, particularly revolving around building trust. Often these issues would appear to go to the heart of what is required for a true SEM, and in so doing cross into the territory of sovereignty and domestic politics. Much of this fundamental terrain the New Zealand Government indicated it was not ready for. As Edward Kane has noted in regard to integrating the two banking systems, Australian Treasurer Peter Costello saw dual banking supervision as only generating duplication and cost, whereas the New

\footnotetext{
311 Kedgley. Ibid. Kedgley argued "We need to debate openly such questions as are we happy to give up our sovereignty and control over a range of day to day decisions that affect our everyday lives to a series of so-called trans-Tasman institutions but which are essentially Australian organisations...”.

312 Norris. Ibid.

313 See for example: Van der Bergh, Roeland. "Hostility to Aussie banks irks ANZ boss". The Dominion Post. 30 April 2010. Editorial. "New Zealand business like branch of Australia". The New Zealand Herald. 30 March 2006.
} 
Zealand view was "... two heads were better than one". ${ }^{314}$ On issues like banking regulation, a single capital market and a common currency (although there was plenty of New Zealand attendees who supported the idea), the two countries had, it seemed, on these particular issues, taken opposite perspectives.

\section{Australian Interests}

In 2004 there was a perception that "New Zealand may be slipping off Australia's strategic radar" ${ }^{315}$ Yet with a strong burst of Australian investment in New Zealand in the 2000s, John Howard and his Government had New Zealand very much in their sights. As they are mandated to do as political leaders, Costello, Downer and Howard were advancing Australian economic interests, and this was noticeable at the meetings. It is notable that Australian investment in New Zealand more than doubled between 2001 and 2006 from NZ\$32.4 billion to NZ\$68.77 billion. The smooth operation of business in New Zealand was thus important for the Australians: a downturn in the New Zealand economy could potentially cause complications in the Australian economy. Australian businesses and politicians were particularly conscious of the changes taking place in the world economy and the opportunities a stable New Zealand presented.

Unlike New Zealand, the Australian Government had fewer qualms about pushing Australian corporate interests. Alongside supporting their banks the Australian government pushed for discussions on unbundling Telecom New Zealand's network in order for Telstra (which in 2005 was fifty one percent owned by the Australian Government) to gain access to Telecom's copper lines through its subsidiary TelstraClear. ${ }^{316}$ This episode is interesting because, according to Fran O'Sullivan, when Telecom chief executive Theresa Gattung became aware that TelstraClear was part-sponsoring the ANZLF and would promote the erosion of Telecom's network monopoly while in Wellington, she prompted McDonald to ensure the Forum did not become "subverted by narrow commercial interests". ${ }^{117}$ On this note, the New Zealand Government attempted to keep trans-Tasman telecommunications regulation off the agenda, though it did not stop Australian ministers raising the issue in

\footnotetext{
314 Kane, E. J. "Confronting divergent interests in cross-country regulatory arrangements". Reserve Bank Bulletin. Vol. 69. No. 2. 2006, pp. 5-17.

315 "Bridging the Tasman". Ibid.

316 Taylor, Kevin. “Anzac dollar splits firms". The New Zealand Herald. 15 May 2004.

317 O’Sullivan. "NZ Inc set up to avert Aussie takeover at summit”. Ibid.
} 
track-one on behalf of Telstra while in Wellington. ${ }^{318}$

Aside from the economic gains from a larger market, another rationale for deeper Australian engagement was strategic. With Australia having concerns over the Pacific's "arc of instability" and the correlated potential for transnational crime and terrorism, New Zealand became more important to Australia. Not unlike former Australian Deputy Prime Minister and CER pioneer, Doug Anthony, who agreed to CER because he was concerned with New Zealand's economic stability and its "borrow and hope" policies, Howard and Downer also had concerns for New Zealand's downsizing of military expenditure, and were increasingly viewing Wellington as a weak link in the chain and as a potential safe haven or back-door entry for "undesirables". ${ }^{319}$ New Zealand defence spending and strategy were contentious topics at the first two Forums, and held up the Forum's common border ambitions.

Days out from the first Forum, Downer brought defence into the Forum dialogue by suggesting that New Zealand should reconsider its nuclear ships legislation. Downer dipped into sensitive New Zealand domestic matters by saying "I regret that the Bolger Government didn't use the opportunity that it had to deal with this issue". ${ }^{320}$ Defence thus became a hot topic at the first meeting. With five members of the Australian delegation serving, or having served, in positions in defence, the New Zealanders were not prepared for the dressing down. Peter Hempenstall described the atmosphere:

\begin{abstract}
"The tensions of New Zealand's inherently different strategic perception of regional and world threats collided head on with Australia's less comfortable, more proactive stance. Senior Australian officials pointed up arguments for the national interest, the move to bilateral alliances, the billions of dollars required of defence expenditure. In stark contrast the New Zealand speaker presented a softer, reasoned argument for multilateralism, with an implied questioning whether Australia's approach was making for a safer world. The dismissive response by a senior Australian politician expressed better than anything the different positioning of each country, even if and when all other issues found their resolution". ${ }^{321}$
\end{abstract}

The defence issue was brought up again in 2005, when an Australian businessman stated that anti-nuclear legislation was a "dead cat on the table". ${ }^{222}$ McDonald stressed that

\footnotetext{
318 O'Sullivan. "Let's see a real inquiry into the Telecom leak". Ibid. O’Sullivan. "Cullen's roars aren't going to serve him”. Ibid. Griffin, Peter and O’Sullivan, Fran. “Australia presses NZ to break Telecom monopoly". The New Zealand Herald. 14 May 2004.

319 Holmes, Frank Sir. Policy Paper No 14: An ANZAC Union? Institute of Policy Studies. Wellington 2002, p. 5 .

320 O’Sullivan, Fran. “Australia snipes at NZ nuclear ban”. New Zealand Herald. 13 May 2004.

321 Hempsenstall. Ibid, p. 3.

322 O’Sullivan. "From Beach Barbie to Power Play". Ibid.
} 
while the defence relationship was not intended to be a major topic on the agenda "nothing is off limits...if participants want to raise an issue and debate something the [Australian] head of defence is there". ${ }^{323}$ Kerry McDonald later claimed that from a New Zealand perspective the benefit of bringing defence into the dialogue had a strategic element for the New Zealand Government - that is, they were able to gauge how the issue affected Australia's willingness to deal with New Zealand. ${ }^{324}$ As former New Zealand Deputy Prime Minister Jim McLay stated at the meeting, it seemed evident that "given the differences on security and defence policies, the dialogue between Australia and New Zealand often resembled the dialogue of the deaf'. ${ }^{325}$ Fran O'Sullivan commented that McLay's remarks and frankness were "symptomatic of a new and more confident boldness and maturity from the New Zealand side in the trans-Tasman dialogue". ${ }^{326}$

\section{Consensus}

Peter Hempenstall observed that at the 2004 and 2005 meetings two types of dialogue had taken place. ${ }^{327}$ One was focused on the divergence in business rules and regulation that placed a wedge between SEM ambitions. The second was the way in which the two countries perceived each other, and the ways in which the respective societies were changing and how that might affect or influence economic integration in the future. In addition, participants on the same delegation also had an opportunity to explore and trade views with each other. This led to an emerging consensus on certain issues. For example, the issue of a shared currency was a contentious topic in 2004 that played out between advocates for and against in both delegations, but by the end of the 2005 meeting it was clear that a SEM would not consist of a currency union in the near future. Constructive debate helped play these conflicts or misconceptions out in an open environment and provided some much needed catharsis. By the end of the 2005 meeting the ANZLF had established and developed some common ideas as options were narrowed down and a general consensus as to the scope of the Forum began to emerge.

The 2004 meeting articulated that the primary purpose of the ANZLF was to "interact with government and with broader business and union interests and the

\footnotetext{
323 Ibid.

324 McDonald. Interview. Ibid.

325 O'Sullivan. "Too many voices for single market". Ibid.

326 Ibid.

327 Hempenstall. Ibid, pp. 6-7.
} 
community, to help progress complex policy issues". ${ }^{328}$ The 2004 Forum saw the adoption of the largely aspirational objectives of creating a common border, accelerating SEM work with the aim of creating a seamless trans-Tasman business environment, and enhancing the skill base of both countries. ${ }^{329}$ The 2005 Forum made its official objective more succinct but no less broad by promoting the creation of a common border in which capital, goods, knowledge, people, and services could flow unimpeded. ${ }^{330}$ The 2005 meeting resulted in a clear consensus that trans-Tasman issues should be tested against a "net-benefit test" applied across the two economies as they pursue a SEM, ${ }^{331}$ and the major plan of action was to establish a common border by 2010 , alongside common policies that aligned business law, banking, and taxation.

\section{Getting Down to Business}

The Forum thus formed ten working groups that had been initiated at the first meeting to progress initiatives in between meetings. The common border working group progressed one of the ANZLF's most tangible success stories that arose from the 2004 meeting following a suggestion by Alan Bollard. Bollard held up a sign with an airport photograph that highlighted the "Australian Only" lane and the "All Other Passport Holders" lane through which New Zealanders had to pass. Downer personally took it upon himself to get the rules on single immigration queues for Australian citizens changed to accommodate New Zealanders.

At the second Forum in Melbourne, Downer came back to the meeting saying that in areas over stepping his ministerial mandate, he had failed to convince bureaucrats in Canberra that the gains were worth the costs (as it happens, the costs were merely Australian immigration staff having to stamp New Zealand passports). ${ }^{332}$ New Zealand Customs Comptroller, and co-Chair of the common border working group, Martyn Dunne, picked up the ball and led a charge that quickly saw all trans-Tasman international airports adopting single immigration lanes reading "Australian and New Zealand Passport Holders Only" which came into force on 24 November 2005. Underlining the value of people to

\footnotetext{
328 Jackson and McDonald. Ibid. This was clarified further in 2005 with McDonald stating: "For the avoidance if doubt, we are not duplicating the work of officials but we are seeking to engage collaboratively, to provide support and encouragement". McDonald. Ibid.

329 Jackson and McDonald. Ibid.

330 O'Sullivan. "Too many voices for a single market". Ibid.

331 McDonald. Ibid.

332 Dunne. Ibid.
} 
people links, Dunne achieved what Downer could not because of his strong Australian links relating to his military leadership in East Timor. This became the most tangible and fundamentally important success to emerge from ANZLF discussions over that period. Whilst it is in itself a small achievement, it is, as Martyn Dunne stated, "iconic, it signals a special relationship between Australia and New Zealand". ${ }^{33}$

\section{Detractors}

Naturally enough, however, the Forums of 2004 and 2005 were not without their detractors. As Michael Cullen said in 2006:

"There was considerable dissatisfaction among political leaders on both sides of the Tasman arising out of last year's [2005] conference... And the fact it really tried to focus on broader issues and got buried in the issues of particular companies". 334

In Cullen's view, the ANZLF had been "hijacked by commercial interests at the expense of the bigger picture". ${ }^{335}$ He claimed that the 2005 event (which he did not attend) saw a select number of New Zealand participants protecting their own corporate interests and regulated environments rather than advancing the trans-Tasman relationship. ${ }^{336}$ Indeed, Cullen was correct. Some business participants took advantage of the gathering and attempted to "push their own barrows". According to a number of participants, a few New Zealand attendees from large regulated companies attempted to place roadblocks on the initial proceedings, fearful of the more open market and less regulation that a SEM would bring. Business self-interest in the New Zealand camp briefly diverted the first two talks but was dealt with by Kerry McDonald taking the New Zealand delegation aside at the 2005 meeting in order to mitigate negative views emanating from the small number of participants. McDonald claimed:

"It was frustrating because you had a very strong New Zealand focus on making

\footnotetext{
333 Ibid. Dr Allan Hawke also provided an insiders account of this outcome. Interview. Ibid.

334 Cullen. "Parliamentary Debate". Ibid. Also see, for example: O’Sullivan, Fran. "Cullens snub causes a to-do". The New Zealand Herald. 12 April 2006.

335 Cullen. Ibid. Also see, for example: O'Sullivan, Fran. "Politics back on the Agenda". The New Zealand Herald. 22 April 2007.

336 Cullen. Ibid. Cullen claimed in Parliament: “...unfortunately, last year [2005], it [the ANZLF] turned into a wailing wall of people pushing their own barrows, as opposed to addressing the wider relationship". Also see, for example: “Cullen calls forum a wailing wall”. Television New Zealand. 6 April 2006.
} 
progress, yet you had several people in positions of leadership who were attempting to undermine the process for their own narrow interests". 337

In any case, Cullen played a hand in a co-Chair reshuffle, and his refusal to attend the meeting was interpreted as "thumbing his nose at the Forum". ${ }^{338}$ In contrast to the New Zealand delegation, some Australian business participants saw the ANZLF as an opportunity to criticise what was viewed as heavy-handed Australian regulation compared with New Zealand's looser regulatory requirements. However, an Australian attendee noted:

"Business people did not do their homework on the very bureaucratic nature of what was driving greater restrictions on movement and integration. So a good number of the issues they attempted to make initiatives were off the mark. Government had to be overridden to get anywhere". 339

Michael Cullen also refused to attend the third meeting. ${ }^{340}$ He told parliament that the ANZLF was not a good use of his time due to the continued advocating for the mutual recognition of imputation credits issue to be resolved. ${ }^{341}$ Cullen publicly attacked an ANZLF participant, PriceWaterhouseCoopers Chairperson John Shewan, who had been strongly advocating such a move in order to progress the SEM agenda. ${ }^{342}$ Although Cullen supported the idea and had been subtly driving it behind the scenes, it was an Australian non-discussible, and Cullen was cautious over two possible trade-offs that had domestic resistance and difficulties in obtaining a parliamentary majority at the time: an investment protocol or sole banking regulator.

Fran O'Sullivan summed up the atmosphere of the 2004 and 2005 meetings by observing that the view of the New Zealand officials: "was let's take the smaller stuff, let's take the incremental stuff, let's take stuff that New Zealand politicians might be prepared

337 McDonald. Interview. Ibid.

338 O’Sullivan. "Cullens roars aren't going to serve him". Ibid.

339 Correspondence between anonymous participant and author. June 2010.

340 Cullen claimed in Parliament that the reason for non-attendance was he had a budget speech to write. He added: "Certainly, all the information I have is that very few major Australian leaders are going to be there at this year's conference". Cullen. "Parliamentary Debate". Ibid. Opposition National Party Finance Spokesman John Key said it was "a disgrace" that Cullen was again snubbing the two-day meeting. New Zealand National Party. "Cullen's failure to front at forum a disgrace". Press Release. 6 April 2006.

341 Cullen. "Parliamentary Debate". Ibid.

342 Ibid. 
to look at and not worry about anything else". ${ }^{343}$ Whereas others, such as Jackson, were more willing to push the bigger, more substantive issues required to bring a comprehensive SEM to fruition. After two Forums, this approach was one reason why her tenure ended after the 2005 meeting, and an indication that the Government had added another track to the bilateral relationship whilst retaining authority to shape ANZLF arrangements and direction. Thereafter, to appease political will it became generally accepted that a SEM would remain aspirational and would only be achieved if the Forum did not raise issues that threatened the sovereignty of either country.

\section{6-2007}

\section{Consolidation}

After the 2006 ANZLF in Auckland, political commentators and participants agreed that the relationship was less centred around disagreements than previous years and there was a positive change in pace and activity. ${ }^{344}$ With defence issues put aside, Allan Hawke believed the two nations were becoming more cooperative and the relationship more healthy, as each made a more serious attempt to recognise the differences that had been emphasised at the first two Forums. ${ }^{345}$ Regular attendee John Shewan commented that the Auckland meeting struck a better balance between business and political visions. ${ }^{346}$ Fran O'Sullivan's view was more frank: "the debate has for far too long been prescribed by politicians' desires to ensure the [non]'discussables' remain off the agenda, but there are signs things are changing". ${ }^{447}$ This was particularly evident in 2007, a Forum which Shewan regards as particularly successful in producing more convergence and agreement than any before. However, as the Australian co-Chair, James Strong noted, the ANZLF still remained a long way from the SEM objectives. ${ }^{348}$

These generalities aside, attempts to actually remove larger barriers restricting business and trade still proved difficult. The New Zealand Herald's Economic Editor and ANZLF participant Brian Fallow summed up his perspective in an article entitled "Leadership Forum fails to tackle the big issues". Fallow noted that one 2006 attendee

343 O'Sullivan. "Politics back on the Agenda". Ibid.

344 Hempenstall. Ibid. Fallow, Brian. "Leadership Forum fails to tackle the big issues". The New Zealand Herald. 7 May 2006.

345 Hempenstall. Ibid.

346 Shewan. Ibid.

347 O'Sullivan. "Too many voices for a single market". Ibid.

348 Ibid. 
claimed:

"[The] networking was wonderful but when I go back on Monday I don't know what I could say we have accomplished, or likely to accomplish next year; what's the point in having a gathering like this and not debating the big issues?"349

Without the drivers of a SEM, Michael Cullen and Peter Costello, at the 2006 Forum, and Alexander Downer the only Australian Minister present, the possibilities of making more substantive gains were largely diminished. While a consensus around a number of issues related to a SEM were emerging, Fallow also observed that the big issues of a common currency, common border, a single capital market and the mutual recognition of imputation credits "remained parked in the too-hard basement". ${ }^{350}$ Instead, business aspirations for a SEM had to be satisfied with some smaller achievements, such as gains in a treaty on the Mutual Recognition of Securities Offerings, a revised Memorandum of Understanding on the Coordination of Business Law, and closely coordinated (though not single) regimes for banking oversight, competition regulation and mutual enforcement of regulatory schemes, as well as the joint immigration lines at airports.

Coinciding with this change in progress were the working groups that were set up following frustration from the first meeting to make progress on issues. Between 2005 and 2008, the working groups reported on progress to the co-Chairs becoming, as Hempenstall stated, the ANZLF's engine. ${ }^{351}$ The working groups had mixed success and some were more active than others. The groups that had the most success have a common thread in that they had officials leading them and they worked on topics that were the least politically sensitive on the Forum's agenda and/or were subject to less domestic debate, such as securities law, competition law and accounting standards, as well as a single track model for company mergers. Paula Rebstock, chairperson of the Commerce Commission, chaired a Forum working group which was mandated to provide a business perspective on trans-Tasman coordination of the competition and consumer law regimes. ${ }^{352}$ The working group had been, as Rebstock stated, "particularly useful and contributed significantly to the development of the merger review protocol agreed by the two Commissions at the July

\footnotetext{
349 Fallow. Ibid.

350 Ibid.

351 Hempenstall. Ibid, p. 7.

352 Rebstock, Paula. "Speech to Trans-Tasman Business Circle". 4 September 2006.
} 
[2006 ANZLF] meeting". ${ }^{353}$

The 2007 Forum was promoted as a stock-take on progress and also put new items on the agenda, such as climate change. For example, Simon Upton, former National Minister for the Environment (1990 to 1999), suggested a closer trans-Tasman policy approach to carbon markets and overcoming the food miles dilemma, reducing emissions and protecting exporters. ${ }^{354}$ The idea Upton suggested would later form the basis of the Global Research Alliance on Agricultural Greenhouse Gases, ${ }^{355}$ one of the National Party's key foreign policy initiatives.

Although both Costello and Cullen reengaged in the dialogue, the stock-take was minor and the Forum meeting unremarkable. ${ }^{356}$ To be sure, for the first time Australian ministers outweighed their New Zealand counterparts, and also contributing to a heightened energy were new co-Chairs, and a growing sense of collegiality among regular attendees. Some SEM progress was announced, primarily in terms of agreeing on a protocol that any regulation proposals in one country meant the other country would be taken into account in order to improve compatibility. Leadership Forum work was also underway, for example in reducing freight and travel costs - however, without a great deal of tangible outcomes directly emanating from the Forum, some participants began to question the process.

A number of participants remained sceptical of governmental commitment to make the paradigm shift required to forge a closer economic union. Although Australian officials and ministers remained engaged at the Forum meeting, it was difficult to get traction from the Australian Government back in Canberra, which was no doubt more focused on upcoming elections. Participants found it equally cumbersome to convince the New Zealand Labour Government that the big issues needed to be addressed, including an investment protocol. ${ }^{357}$ Subsequently, it seemed in 2007 that confusion surrounding the role of non-official participants in the process, and governmental inaction to seriously

\footnotetext{
353 Ibid.

354 O'Sullivan, Fran. "Daunting challenge to feed the world". The New Zealand Herald. 7 April 2010.

355 See: Global Research Alliance on Agricultural Greenhouse Gases website.

www.globalresearchalliance.org/ (Accessed: 23/01/11). When asked about the idea, Hon. Upton stated: "I've always thought that the parentage of good ideas is less important than the fact that they are taken up. Mr Key was of course not Prime Minister at the time, but if he and Mr Groser picked up some good ideas there (from memory they attended as Opposition leaders) then that suggests the Forum is doing its job". Private Correspondence 17 November 2010.

356 O'Sullivan, Fran. "ANZAC Spirit falters on the trade front”. The New Zealand Herald. 25 April 2007.

357 This view was supported by several business leaders interviewed, including Kerry McDonald and James Strong.
} 
advance the agenda despite its rhetoric led some participants to walk away from the ANZLF. Co-Chair James Strong described the difficulties of conducting the event:

\begin{abstract}
"There was always this struggle to get people to identify practical issues where something could be done, and try and convince the governments to do it and get it on their priority list, and it was tough going in those earlier years - It [the ANZLF] never got as high as it should have. While there was good participation... there was a pronounced lack of progress". ${ }^{358}$
\end{abstract}

\title{
$\underline{\text { 2008-2009 }}$
}

\section{Step-Change}

Following changes in government on both sides of the Tasman there was a step-change in the ANZLF and advancements on its objectives. In 2008, after more than a decade out of office, Australia's new Labor Government appeared to make a concerted effort to demonstrate that Kevin Rudd intended to take care of "unfinished business" and tackle issues that had remained sidelined. ${ }^{359}$ Rudd sent a strong signal to atone for oversight in scheduling the 20/20 Summit the same weekend as that year's Forum, requiring the ANZLF to defer the meeting for several months. While he did not attend, he sent the largest Australian delegation of ministers (six), including Deputy Prime Minister Julia Gillard, to ever visit New Zealand simultaneously, and specifically to attend the Forum. Gillard publicly reaffirmed the role of the Forum in facilitating the SEM process and used the opportunity to acquaint New Zealand business and political leaders with the Rudd Government. ${ }^{360}$

The reason for the large contingent may not, in fact, be so straightforward. Due to an initial lack of Australian interest, the 2008 Forum came very close to cancellation by the New Zealand Ministry of Foreign Affairs and Trade. Due to a lack of secretariat support and over-reliance on a personal assistant, James Strong failed to put in enough pre-Forum planning. Australian Trade Minister Simon Crean, Phil Goff and the Australian High Commissioner to New Zealand, John Dauth, stepped in and applied "behind-the-scenes pressure" to muster a strong Australian contingent, and Rod McGeoch assumed the

\footnotetext{
358 James Strong. Ibid.

359 O’Sullivan. "Crean pushes agenda on investment". Ibid.

360 Gillard, Julia. "Priorities for the Australian Government". Speech to the Australia New Zealand Leadership Forum. Wellington. 13 June 2008.
} 
co-Chairing role for the meeting. ${ }^{361}$ Some New Zealand officials considered cancelling the meeting and making it biennial. As Simon Murdoch recalled: "I started to wonder that it might be better not to hold it at all rather than have a bad one". ${ }^{62}$ Gillard felt compelled to emphasise that the difficulties were not a signal of disinterest, highlighting the fact that she was departing Australia while acting-Prime Minister, which should be seen as an indication of how seriously Australia considers the bilateral friendship. ${ }^{363}$

However, a large delegation did come, and regardless of the precise concatenation of circumstances, some progress on SEM issues was undoubtedly made. Cullen stressed at the 2008 ANZLF that incremental but important changes had eliminated most barriers to trade, while substantial work had been done on the less visible barriers to business en route to a SEM. ${ }^{364}$ Progress in 2008 included concluding the Treaty on the Mutual Recognition of Securities Offerings; ${ }^{365}$ a new Cooperation Agreement by the New Zealand Commerce Commission and the Australian Competition and Consumer Commission; the sharing of information between the New Zealand Companies Office and the Australian Securities \& Investments Commission; and a move closer towards a harmonised corporate insolvency regime. ${ }^{366}$ The first three initiatives can be directly linked to the Leadership Forum and the working groups. The ministerial presence at the fifth meeting in Wellington meant more speeches and political posturing which clearly overwhelmed the business delegates. As an example of the "autonomy dilemma", Brian Fallow observed that from his perspective the general feeling of business leaders was:

"We must pick up the pace of progress towards a single economic market," said the politicians. "Couldn't agree more" said the business leaders. "Keep up the good work". No sense of urgency, no added impetus or clarity of focus... the business delegations dropped the ball" ${ }^{367}$

\footnotetext{
361 O'Sullivan, Fran. “A forum that almost didn’t happen”. The New Zealand Herald. 14 June 2008.

362 Murdoch. Ibid.

363 O’Sullivan, Fran. "Clark signals Rudd - Please ask next time”. The New Zealand Herald. 14 June 2008.

364 Cullen, Michael. "Speech to the Australia New Zealand Leadership Forum". 13 June 2008.

365 In the 2010 Annual Report, the Securities Commission stated: "The Trans-Tasman Mutual Recognition of Securities Offerings regime reduces costs and simplifies compliance for issuers making offers of securities. It continues to be used by more issuers on both sides of the Tasman. By 30 June, 13 New Zealand companies had used the regime 15 times, and 91 Australian funds and companies 343 times, since it was established in June 2008. In October 2009, the Australian Securities and Investments Commission published results of an issuer poll conducted on both sides of the Tasman on the effects of the mutual recognition regime. It showed that mutual recognition arrangements save issuers between 55 percent and 95 percent in the additional legal and documentation costs of capital-raising in the host country". The New Zealand Securities Commission. 2010 Annual Report. Wellington 2010.

366 Ibid.

367 Fallow, Brian. "Big business happy to take backseat". The New Zealand Herald. 16 June 2008.
} 
Nonetheless, the agenda and attitudes were a marked difference to those in 2004 and the dialogue developed some substance. By 2008 the agenda was centred solely on a SEM with a strong focus on a common border to facilitate the movement of goods and people between the countries, of which the goalpost was shifted from 2010 to 2015. Regional issues of strategic and common importance to trans-Tasman interests were also discussed, for example changing demographics and environmental issues such as the carbon challenge. Strategic opportunities and challenges in shaping trading and economic arrangements in Asia and the Pacific, such as "ASEAN plus Six", the Trans-Pacific Partnership, and the Pacific Agreement on Closer Economic Relations (so-called PACER) were beginning to be discussed. Imputation credits were also on the agenda, however following the failure of the Therapeutics Product Authority and aspirations for a single banking regulator, bi-national institutions were not discussed. Opposition leader John Key observed and engaged in the discussions, stating when he was Prime Minister the following year that the Forum's common border goal of 2015 was "far too long", noting that an agreement should be in place by March $2010 .{ }^{368}$

\section{Reinvigorating the trans-Tasman spirit?}

Similar topics continued at the sixth ANZLF in Sydney the following year. Pacific and regional issues were the first topics discussed at 2009 meeting, as well as discussions on carbon markets and climate change, promoting clean food and energy, the global economy and financial crisis, defence (focused on the interoperability of defence forces rather than a New Zealand military resource deficit), a common border (with a new aim to make trans-Tasman travel a "domestic-like experience"), a taxation review, and a CEO panel discussing the practical challenges for trans-Tasman companies. Finally, leaders of the Opposition were given the stand to close the session.

The Forum of 2009 suggested a precedent may have been set by Rudd the year before, as in 2009 the National Government offered a similarly large entourage of ministers to the Forum. Not only was it the first time Prime Ministers featured on the participant list, but Key took with him six key ministers who participated in what was billed by the media as a joint trans-Tasman cabinet meeting (despite the fact that it is

368 Ansley, Greg. "Common border high on PMs list”. The New Zealand Herald. 3 March 2009 
constitutionally impossible), and also brought an ensemble of government agency heads to attend the Forum. ${ }^{369}$ With Key's top ministers in Sydney, unusually, number five in the cabinet, Minister for Health Tony Ryall was Acting Prime Minister for three days.

Prime ministerial attendance demonstrated that gains and oversight are required from the top to give impetus to the agenda. ANZLF co-Chair Rod McGeoch commented on the injection of new energy into the trans-Tasman agenda: "they're new and they want to make their mark and that's permeating right down through the ministers". ${ }^{370}$ Both Rudd and Key gave passionate speeches (without speech notes) at the Forum dinner. They highlighted the growing potential for the future relationship and expressed their willingness to provide the political capital required to move the SEM project forward. Advancing New Zealand interests, the political drive had a significant effect in providing an impetus to break Australian bureaucratic blockages and change perceptions. A regular attendee, Jane Diplock from the New Zealand Securities Commission explained:

"There has been the feeling from some [Australian] bureaucrats I have spoken with, that New Zealand was just another state - so why would you give them a break or any special treatment? It has become clearer to me particularly at the last one [the 2009 ANZLF] that the two Prime Ministers putting energy and commitment into the Forum provided the political impetus to those bureaucrats to have to do something". ${ }^{371}$

As a result, longstanding issues were beginning to see the light, and general attitudes had clearly and positively changed. In 2009, the shift in agenda from discussing national attitudes thus saw a more intense focus on what had been unachievable in 2004: asserting and positioning both countries on the global stage. As a New Zealand participant noted: "We were not just talking about Australia and New Zealand, but how Australia and New Zealand can take on the world, and I think everybody agrees about this idea". ${ }^{372}$ A very real revitalisation of trans-Tasman relations was apparent when the Prime Ministers announced they were willing to put aside certain national interests by positioning

\footnotetext{
369 The New Zealand Cabinet group included: Bill English, Gerry Brownlee, Murray McCully, Simon Power, Tim Groser, Wayne Mapp and Steven Joyce. All attended the ANZLF. The Australian Ministers present at the Forum included, Kevin Rudd, Wayne Swan, Simon Crean, Stephen Conroy, Penny Wong, John Faulkner, Anthony Albanese and Martin Ferguson.

370 O'Sullivan, Fran. “Tricky issues on transtasman agenda”. The New Zealand Herald. 21 August 2009.

371 Diplock. Ibid.

372 Stephen Jacobi. Executive Director, New Zealand International Business Forum. Personal interview conducted April 2010.
} 
themselves collectively on particular issues and seeking a net Trans-Tasman benefit. ${ }^{373}$

At the Sydney meeting, John Key and Kevin Rudd put forth a proposal for a

trans-Tasman "brand". They proposed joint economic ventures in order to project an image of a globally reputable and dynamic region (or in Key's words, "the Australia-New

Zealand brand: quality, vitality, and a lifestyle that reflects who we are"), with a main emphasis on benefiting from the Asian economies. ${ }^{374}$ In branding the two countries collectively in certain areas, the objective was not only to encourage Asian investment and position the two countries for the "Asian Century", but also to look at eliminating, for instance, the duplication of trade offices and embassies around the world, a proposal actively discussed at the 2008 and 2009 Forums. $^{375}$ As John Allen stated, by working together there is "the opportunity to market and represent the two countries collectively on the world stage, especially in areas where the two might achieve results in places where one country alone may not", ${ }^{376}$ affording not just opportunities to achieve much more than New Zealand might be able to achieve on its own, but in some cases also reap fiscal benefits. Other Forum proposals for “Australasia Inc.” have included collaboration in agricultural, scientific and educational research, an educational fund, complementary climate change emissions schemes, joint aid activities and trade promotions, and pro bono work has been undertaken on changing the way in which pharmaceutical schemes are funded, and examining the "silos" of respective government agencies in order to find areas where agencies could consolidate similar functions.

373 Key, John and Rudd, Kevin. "Joint Statement of Intent: Single Economic Market Outcomes Framework". 20 August 2009. "The outcomes framework supports an aspirational Single Economic Market (SEM) agenda, and will in the short-term drive pragmatic initiatives and set clear timelines for the work programme. A key element within the framework is a deliberate move from consideration purely of national benefits in policy development, to consideration of the net trans-Tasman benefit". The principle takes the trans-Tasman relationship to a new level. A cabinet paper described the trans-Trans benefit as "a significant new element in explicit trans-Tasman messaging" which "would move beyond each side applying a narrower net national benefit test on an issue by issue basis to embracing a longer term more strategic calculation of overall balanced benefits across a broad number of areas of endeavours within the SEM". However, some have suggested that insufficient thought has been given to the concept. See for example, Shirtcliffe, Geof. "Seven Steps to Heaven or a step too far?" Chapman Trip Brief Counsel. 9 November 2009.

374 Callick, Rowan. "Opposite Attracts in renewed trans-Tasman friendship". The Australian. 31 August 2009. It should be noted that this was not a new idea (arguably, it goes back to the 1800s). Michael Cullen floated the concept in March 2005 stating "As I said at the outset, creating a single Australasian domestic economy is one of two important goals. The other is externally focused. How can we leverage our respective strengths in building our export performance? How can we create, in reality if not in name, a kind of ‘Australasia Inc'?” See: Cullen, Michael. “Address to NZ Gala Day Dinner”. 9 March 2005. www.beehive.govt.nz/node/22396 (Accessed: 01/12/10).

375 A combined approach to sharing Embassy office space is currently being considered by MFAT, most prominently in their "spoke and wheel" initiative to centralise administrations from a central Embassy with a number of Ambassadors in peripheral posts - in some cases running a post single-handedly.

376 John Allen, Chief Executive Officer and Secretary of the New Zealand Ministry of Foreign Affairs and Trade. Interview conducted October 2009. 
Political announcements made at the 2009 ANZLF also included plans to advance a number of collaborative initiatives by 2015 (the centenary of Gallipoli). An emphasis was placed on streamlining trans-Tasman travel arrangements with harmonised immigration and customs procedures (including the Smartgate clearing systems); ${ }^{377}$ and increased and targeted scientific collaboration (while at the Sydney Forum, Ministers Gerry Brownlee and Kim Carr signed a collaborative arrangement to bid for the world's most powerful telescope, the Square Kilometre Array). Key and Rudd stated they would promote further progress in closer defence relations in order to achieve common regional security objectives. They proposed the formation of a case by case joint ANZAC military contingent and further inter-operability of the respective armed forces. ${ }^{378}$ This, they proclaimed, would "reinvigorate the ANZAC spirit". ${ }^{379}$

Prime Ministers Key and Rudd surprised ANZLF participants and proved to be, at least in the short term, driving forces in pursuing ANZLF objectives by emphasising the importance of achieving tangible results rather than simply raising options and ideas. ${ }^{380}$ Rod McGeoch quipped that preceding the 2009 meeting, he and Simon Crean observed Key and Rudd in deep conversation, which prompted Simon Crean to comment: "We are terrified, we don't know what they are agreeing to". ${ }^{381}$ In Sydney, the two Prime Ministers committed to a Single Economic Market Outcomes Framework that set out a number of principles to accelerate regulatory harmonisation and alignment. Mandated to oversee the work was the bi-national Trans-Tasman Outcomes Implementation Group (TTOIG) jointly

\footnotetext{
377 SmartGate provides some travellers arriving into Australian and New Zealand international airports the option to self-process through passport control, by using ePassports and face recognition technology.

SmartGates allow the traveller to perform the standard checks that are usually conducted by a Customs and Border Protection officer.

378 See for example, Callick. Ibid. Editorial. "Resurrection of ANZAC contingent mutually beneficial". The Press. 28 August 2009. Nicholson, Brendan. "Kiwi call to arms: PMs join forces to revive Anzac spirit". The Sydney Morning Herald. 21 August 2009. Australian and New Zealand military and police forces have already worked together in the Solomon Islands, East Timor and in Tonga, among other conflicts, and they often share military transport and specialist equipment.

379 Key and Rudd. Ibid. In addition, Key and Rudd announced that much work had been done on competition policy and consumer protection, intellectual property, accounting standards, securities offerings, cross border systems, insolvency law, company registrations, an updated double tax agreement, and a review of the Rules of Origins and Trans-Tasman Mutual Recognition Arrangement, amended the Joint Food Standards Treaty, and revised double taxation arrangements. The Arrangement of Trans-Tasman Retirement Savings Portability has concluded but yet to come into force.

380 James, Colin. "Stronger together in an uncertain world". The Press. 8 August 2009. James claimed the tone had shifted immeasurably: "Officials have been told to produce results, not examine options, which in the past has given them (mainly in Canberra) scope to find reasons not to do things. Whether that will turn out to be a magic pudding or one to be proved in the eating will need time. But for now the two new Prime Ministers are injecting energy into pushing us closer. The vogue phrase is "stronger together" - in a wide, unpredictable world. It's taken a while".

381 McGeoch, Rod. "Speech to the Trans-Tasman Business Circle". Auckland. 15 February 2011.
} 
chaired by the Australian Treasury and the New Zealand Ministry of Economic Development (see Appendix Five). What is not readily accredited to the ANZLF is that the framework, as Phil O'Reilly from Business New Zealand claimed, is a part of the nature of influencing an incredibly complex process: "that is a direct result of successive ANZLF meetings and what happened as a result of that. That was not dreamt up by officials in a box, they were listening to that". ${ }^{382}$ The seven principles of the framework are:

- Persons in Australia or New Zealand should not have to engage in the same process or provide the same information twice.

- Measures should deliver substantively the same regulatory outcomes in both countries in the most efficient manner.

- Regulated occupations should be able to operate seamlessly between each country;

- Both Governments should seek to achieve economies of scale and scope in regulatory design and implementation.

- Products and services supplied in one jurisdiction should be able to be supplied in the other.

- The two countries should seek to strengthen joint capability to influence international policy design.

- Outcomes should seek to optimise a net Trans-Tasman benefit.

To be sure, not all the initiatives listed above or that took place between 2004 and 2009 can be directly attributed to the ANZLF. Indeed it is imaginable that many of the legislative changes and agreements that have been made since 2004 may have been introduced at some point, but the Forum has undoubtedly contributed to the expediting of this. As Jane Diplock stated: "Frankly, mutual recognition stuff would have languished had the Leadership Forum not given it a kick along". ${ }^{383}$ For example, post the 2009 Leadership Forum, Commerce Minister Simon Power ${ }^{384}$ instructed officials to focus on an exhaustive list of SEM issues, such as financial reporting, managed funds, intellectually property law, insolvency proceedings, and anti-competitive conduct. Diplock also noted that the Forum not only elevated trans-Tasman issues in the minds of the Australian Treasury and the bureaucracy in general, but crucially it forced officials to report back on progress to

\footnotetext{
382 Phil O’Reilly. Chief Executive Officer, Business New Zealand. Interview conducted 24 June 2010. 383 Diplock. Ibid.

384 Hon Simon Power has a range of portfolios and several Australian counterparts. He is Minister of Justice, Minister for State Owned Enterprises, Minister of Commerce, Minister Responsible for the Law Commission, Associate Minister of Finance, and Deputy Leader of the House.
} 
non-officials at the meeting:

"If it had just been bureaucrat to bureaucrat I don't think it would have had the same power; ministerial commitment really changed the priorities at the bureaucratic level which is where the work has to be undertaken". ${ }^{385}$

Indeed, most ANZLF objectives require ministerial attention, and if the 2009 Forum is any measure, the National Government has recognised that the importance of the event extends beyond constituency building. Under Key's watch, the ANZLF was used as a platform to draw a lot of attention in Sydney to trans-Tasman concerns, announce achieved goals, and launch new initiatives to what was largely becoming a business audience. Furthermore, Murray McCully observed that the ANZLF had played "a major role in bringing together key political figures. It is an important opportunity for us to get to know more about what makes Australia tick, and to outline where the new Government see New Zealand heading in the coming years". ${ }^{386}$ Simon Power commented that he is in regular contact with his Australian counterparts:

\begin{abstract}
"Both Prime Ministers were engaged in the [SEM] issue and any blockages at official level were nothing a phone call couldn't solve...it [the SEM] has been very much a government to government thing... I share your view that we could do better. There must be some boxes for Prime Ministers to have ticked each time they meet rather than just meeting and saying 'this is a good relationship"." 387
\end{abstract}

Whether Australia and New Zealand ministers were listening to ideas emanating from the 2009 meeting is difficult to prove conclusively. What is known is a SEM is not a treaty that can be signed, sealed and delivered. Rather, it is a process that spans an array of different policy areas, and therefore the various policy processes will take place over consecutive governments. In many areas any given Australian government has to deal with inter-state discrepancies before agreements with New Zealand can be made. In some cases it takes a great deal of time for agreements to become legislated in the respective jurisdictions. For example, savings portability legislation, which allows retirement savings from certain Australian superannuation funds to be transferred into New Zealand

\footnotetext{
385 Diplock, Ibid.

386 "NZ likely to extend deposit guarantee scheme". The New Zealand Herald. 20 August 2009.

387 "Work continues on single economic market". National Business Review. 3 June 2010.
} 
KiwSaver funds, was passed in New Zealand but has yet to be passed in Australia.

Non-governmental participants have found the arduous process frustrating. Beyond raising ideas directly at the Forum, which are left with officials to progress, the greatest opportunity that the non-official ANZLF participants have had to contribute directly to that process has been through the working groups.

\section{Dissipation of the working groups}

The persistent commitment of some participants and working groups to constructively debate and move the Australian and New Zealand relationship forward has proved rewarding. John Shewan, leader of the tax working group, noted that working groups were not as active as they were between 2004 and 2007 because a lot of "low lying fruit had been dealt with, such as the securities law". ${ }^{388}$ Allen and McGeoch refocused on broadening and strengthening official and non-official relationships within the Forum rather than relying on a few participants to carry the working group processes. ${ }^{389}$ Allen felt that working groups may no longer be as advantageous as getting one or two individuals together with officials and politicians to sort out relevant issues. ${ }^{390}$ Getting working groups together was another challenge. ${ }^{391}$ As such, the dedicated working groups that were once required to deal with specific issues were increasingly being replaced by newly established processes and relationships. McGeoch observed that when Key and Rudd "got stuck into the bureaucrats" a lot of the efforts of the working groups were taken over:

“...with great willingness by us... things like capital raising in financial markets, the Australian Competition and Consumer Commission and competition issues, and listing requirements, all that got done and we drove it, and they carried on and fixed it.... We thought we had stirred up enough activity with the ministers on quarantine and immigration, ease of travel etc and all of that is work in progress and it's happening and we started thinking about what else here is important?"392

\footnotetext{
388 Shewan. Ibid.

389 Allen. Ibid.

390 Ibid. Allen argued that: "After six forums the relationships are well established: at a business to business level the relationships are good, at a government to government level the relationships are good, and in a bureaucrat to bureaucrat level the relationships are good".

391 Ibid.

392 Rod McGeoch AM, Chairperson Corrs, Chamber Westgarth. Skycity. Personal interview conducted in Sydney 10 August 2010.
} 
Some participants have had a different take on the working groups dissipating. One Australian business participant argued that the combining of issues like tourism or financial integration required the break up into areas of mutual interest, "otherwise things go absolutely nowhere; it's an essential part of making it work". ${ }^{393}$ One attendee from the first three Forums claimed: "working groups fell apart because there was no structure or substance, no consistent pathway for the outcomes to be taken to decision-making bodies". ${ }^{394}$ With no formal structure or support to turn ideas into concrete working papers, and no pathway for some working groups to take their ideas to politicians, that working group member shared a similar frustration with other group members. However, some years later that participant's idea emerged in the TTOIG agenda, demonstrating the considerable duration between some ideas and action. ${ }^{395}$

According to the co-Chairs, over a four year period the working groups have done all they can on the relatively "low hanging fruit" and it is now the job of the ANZLF to point to the "high hanging fruit" that only the two governments can reach. Due to the complexity of further integration there is little doubt from some officials that the working groups will have their time again as new issues arise. ${ }^{396}$ For as the constant oscillations in trans-Tasman history demonstrate, the relationship has regular periods of high and low activity.

\section{0}

\section{At a Crossroad?}

In spite of the hype in 2009, 2010 was remarkably quiet on the trans-Tasman front and the events of 2009 failed to reinvigorate a great deal of policy change. A drift in trans-Tasman relations was also apparent with the absence of the annual Prime Ministerial meeting (indeed, it had been three years since an Australian Prime Minister had visited New Zealand). Fundamental ANZLF objectives remained side-lined and on-going regulatory and legislative impediments remained barriers to the idea of a single market, particularly the common border, and mutual recognition of imputation credits. ${ }^{397}$ The loss of revenue - at

\footnotetext{
393 Australian business executive. Interview conducted August 2010.

394 Australian Academic. Interview conducted August 2010.

395 Upon being informed of the development, the participant stated: "I am thrilled. After all those meetings of me putting forward the idea...something has happened or is happening. I am very heartened as I thought I had really wasted my time in travelling to meeting after meeting and putting forward the same suggestion - only to be told there was no benefit. Yes this is precisely what I had put forward and as I say, I am thrilled!".

396 Murdoch. Ibid.

397 “Air reforms grounded”. Sydney Morning Herald. 8 January 2011.
} 
least half a billion Australian dollars annually - incurred from aligning imputation credits systems has continued to make it an unpopular idea in Canberra. Having made inroads, implementing a common border stalled, revealing the limitations and different ways in which Australia and New Zealand view the security of their borders which, short of a change in paradigm by Australia and the way in which that country assesses its security concerns, were not compatible for European-styled open borders. Instead the two countries have preserved their borders due to politics, security and smaller but numerous issues, such as the incompatibility of customs and immigration data requirements. ${ }^{398}$ Furthermore, requests from Kevin Rudd for a joint approach to forming an ANZAC contingent to serve in a highly dangerous sector in Afghanistan were rebuked by the National Government because the idea conflicted with, and frustrated New Zealand's own strategy and perceived national interest. Cooperation in Asia-Pacific resembled, as Malcolm Cook observed, two countries that were standing together but in single file. ${ }^{399}$

Kevin Rudd was politically toppled by a party coup in June forcing an early election, and diverting attention away from trans-Tasman issues. Rudd had been pursuing a uniform approach to consumer law across the Australian states and New Zealand; and in spite of a commitment to a trans-Tasman net benefit, his interest in a SEM was largely related to the arrangement benefiting Australian companies and investment, such as pension funds and private equity firms that have heavily invested in New Zealand. ${ }^{400}$ Once Rudd lost his Prime Ministerial position, it was revealed that he did not have as much interest in New Zealand as events surrounding the 2009 Forum suggested. The Main Report Group claimed:

“...In Wellington the relief was palpable. Rudd's interventions had frustrated New Zealand in different theatres. He unilaterally pushed taking Japan to the International Court of Justice over whaling at a time when New Zealand's Sir Geoffrey Palmer had come so very close to resolving the conflict within the IWC. Rudd refused to listen to New Zealand's advice on the issue... Rudd's ambition to reorganise world affairs through his role in the G20 didn't wash in Wellington, and since New Zealand didn't acknowledge his concept of Australia as a "middle power," Rudd was reluctant to do

\footnotetext{
398 Dunne. Ibid.

399 Cook, Malcolm. "Standing Together in Single File: Australian views of New Zealand and Asia" Outlook 13. Report for the Asia New Zealand Foundation and the Lowy Institute, p.3. Cook noted that "recent developments in Asian regionalism show that Australia and New Zealand are not standing side by side, arms intertwined. Rather, mirroring their respective geographical locations in relation to Asia, their positioning is in single file, with the bulkier and more assertive Australia perceiving itself at the head, facing forward and, at times, leaving New Zealand behind".

400 James, Colin. "The Anzac deal: just how deep might it go?” The Dominion Post. 26 April 2010.
} 
New Zealand any favours". ${ }^{401}$

There was a general feeling in 2010 that the ANZLF was at a crossroad. Whilst behind the scenes work took place in the Foreign Ministries and other departments, the year passed unceremoniously in terms of building on the events of 2009 and making any large gains in the ANZLF's objectives - in part due to the change of Labor Party leadership in Australia slowing the optics of the process. The rigors of a heavily contested Australian federal election meant the scheduled 2010 Forum in Auckland was deferred until April 2011. Without the possibility of an impressive Australian political line-up, the political response from Wellington was not to have a meeting at all. Interestingly, McGeoch stated that the Australian business participants were very much prepared to attend, and at the very least the Foreign Minister Stephen Smith was in a position to stop in Auckland on his way back from the Pacific Islands. ${ }^{402}$ A number of attendees observed that the networking and constituency building had suffered from the lack of ongoing activity in between meetings, creating a lack of attachment to the event and its objectives. Coupled with the continuing inability by non-governmental actors to seriously influence the agenda, the deferral added more urgency to the fact that the Forum needs to develop a legacy and greater sense of relevance in order to compel people to turn up to future meetings.

The proposed agenda for the 2010 ANZLF was to focus less on intra-country issues than past discussions and more on ways in which Australia and New Zealand can work together further afield. In spite of pessimism from some quarters, John Weiss from the Trans-Tasman Business Circle stated:

"[Co-Chairs] John and Rod are satisfied that the ANZLF is providing a vehicle for previous issues and it's time to be moving on to the big stage, which is Australia and New Zealand together... and there's hardly anything in this year's Forum that's on the SEM. We are satisfied the existing mechanisms are working or are at least being built to pick up on these issues". 403

The shift away from inward looking objectives signalled a continuation of the 2008 and 2009 trajectory of New Zealand and Australia attempting to move into third markets

\footnotetext{
401 Max Bowden's BusinessSense. "Gillard's Accession Creates Uncertainty for Trans Tasman Relations". The Main Report. 5 July 2010.

402 McGeoch. Ibid.

403 John Weiss. Chief Executive Officer, the Trans-Tasman Business Circle. Interview conducted August 2010 .
} 
conjointly - especially Asian markets - an idea that appeared rather distant in 2004. Indeed, since the inaugural meeting there was increased recognition and awareness that even though Australia and New Zealand operate as competitors in overseas markets, their broad strategic interests are remarkably close. However, recognition and awareness have yet to translate into significant action. This is the next challenge and role for the ANZLF.

\section{Conclusion}

The Forum's inability to influence top-down change demonstrates the state-centric nature of the relationship. This chapter has made the case that between 2004 and 2009 the ANZLF has grown and matured significantly along with the broader trans-Tasman relationship, yet it has not been at the expense of government losing an inch of ground as pivotal players. Whilst a trans-Tasman collective of powerful non-state elites have failed to achieve a number of specific goals, such as establishing a common border by 2010 , the Forum has not been without merit. It has played a key role in mitigating nationalistic and defence concerns at the elite level, established a broad policy consensus among business leaders, and remains increasingly crucial to get joint government strategies off the ground.

The influence of the ANZLF cannot be judged by one meeting alone but by the largely intangible consequences of accumulative Forum meetings. Over several years, the ANZLF assisted in ironing out some difficult topics that had constrained the bilateral relationship, and it may do so again in the future. Essentially, the dialogues allowed New Zealand participants, official and non-official, to assert themselves and raise concerns about Australia's potential dominance of the trans-Tasman integrative project. As the ANZLF meetings have progressed the dialogue has become increasingly less about two countries forging a deeper economic relationship between themselves, but looking out at the world to collectively position and market the trans-Tasman world. The negative publicity that marked the relationship in the early 2000s has largely dissipated and a single market between Australia and New Zealand is emerging. The Forum deserves some credit for that.

The ANZLF meetings may have produced a number of intangible outcomes, but it has not achieved what business leaders anticipated in 2004. Overall, the dialogues have served political governance rather than business desires. They assisted the Clark Labour Government by encouraging and supporting the development of "soft" SEM issues (i.e. 
issues unrelated to sovereignty), and developing ideas for policy initiatives and strategies. The complexities of the overall trans-Tasman relationship and initiatives like a SEM mean the respective governments benefit from the involvement of a wider range of actors. But political involvement remains integral. As Key and Rudd showed, having previous experience at the ANZLF as Opposition attendees can have a major impact on future government decision-making and policy. In addition to providing free technical advice, ideas and support, the Forum has assisted in establishing familiarity which has opened up channels of communication - and governments are able to quickly draw on expert advice on challenges facing the region. Above all, as most of the Forum's successful ideas have emanated from, and/or been progressed by officials, it is clear that the role and influence of the ANZLF remains contingent on maintaining a close relationship with track-one. To remain relevant, governments need to respond, therefore high-level political participation and even close governmental oversight of the Forum's agenda remains not simply important; it is arguably essential. 


\section{Chapter Five}

\section{Conclusion - The Role and Influence of the Australia New Zealand Leadership Forum}

This thesis set out to examine the role of the Australia New Zealand Leadership Forum (ANZLF) in the broader context of the trans-Tasman bilateral relationship. In doing so, it traced the Forum's origins, discussed its form and modalities, and looked at the substance of the six dialogues. The thesis also sought to challenge a number of assumptions: that the trans-Tasman relationship is diverging; that the Forum has been of little value; and that the trans-Tasman relationship is seeing the greater involvement of a wider range of non-official actors at the expense of governments as pivotal players. Finally, it questioned whether the ANZLF has served to legitimise the status quo or if it has actually had a transformative and independent agenda of its own.

This study of the ANZLF has argued that the Forum has been valuable; however most of the outcomes have been intangible and primarily benefited the New Zealand government. Chapter two demonstrated that the ANZLF was the result of a diplomatic initiative to address a number of difficult and sensitive issues, and create a stronger elite constituency supportive of closer integration. Modelled on, but not identical to the Australian American Leadership Dialogue, the Forum has performed the socializing and constituency building aspects of soft track-two diplomacy coupled with the political guidance and close oversight of track-one-and-a-half diplomacy. This can be seen in government control over participant type, funding, agenda-setting, and the selection of the co-Chair. It is evident that a strong state apparatus remains essentially unchanged since Federation, and regulatory regimes are not being dismantled but refined and refashioned to meet geopolitical challenges. Indeed, the ANZLF is an example of unofficial diplomacy assisting governments to govern better by drawing on an alternative resource and building strategic relationships with a variety of non-governmental and other bodies to achieve their specific objectives.

From a state-centric perspective this is an understandable and rational development because track-two type processes can enhance state capacity, rather than weaken it. In other words, far from non-official actors exercising more control over the process, in the trans-Tasman context, the opposite is true. Authority for the ANZLF has been retained by the New Zealand Government which has, at least under Labour, shown a clear willingness 
to change arrangements, such as orchestrating a change in co-Chairs after they failed to squash criticism. Like the ill-fated Australia New Zealand Foundation, governments could potentially decide at any point to discontinue the ANZLF meetings. Moreover, as the Australia New Zealand Business Council demonstrated, without political interest, business-led organisations can slide into irrelevance and disintegrate altogether.

However it is classified, New Zealand has gained a great deal through the process, from a more cohesive and supportive non-state elite constituency in both countries, to a rich source of expert advice and ideas. Although the Clark-led Government was clearly cautious about the Forum's role, its development, who participated, and hesitant about a common border and business elites shaping the agenda, it used the ANZLF as an opportunity to advance New Zealand's interests without making large concessions to corporate interests or being swamped by Australia's larger mass. Chapter three suggested that the lack of coordinative infrastructure and investment, alongside an insistence on including union and other community actors, weakened the potential contribution of business to influence the policy-making process (in terms of keeping a sole focus on business, trade and investment issues). Instead, through the ANZLF, the New Zealand government has been able to set limits to the agenda and reduce it towards smaller, more sharply defined goals that fitted in with New Zealand's supportive but cautious approach to economic relations with Australia. Most notably the agenda was steered away from big ideas like a customs union and common currency, and any talk of single institutions gave way to ideas around joint institutions with arms on either side of the Tasman, or simply mutual recognition in uncontroversial areas where it made sense. Instances like this led Kerry McDonald to later conclude that:

"The issue was political. In a way it was typical of the Clark-led Government. They often had good ideas and set up a process, and they talked about it, but delivered nothing, and I would say that was the key characteristic of the Leadership Forum". 404

Another perspective is that the Labour Government deftly took the ANZLF and trans-Tasman relationship in general to a position where New Zealand's views on certain issues were known and understood in Australia. The ANZLF has extended the lines of

\footnotetext{
404 McDonald. Ibid. McDonald added: "On the positive side, it [the ANZLF] got very good engagement with Australian business across numerous areas, there was working groups set up. It lifted the bar for officials and got them working more actively, and it encouraged more minister to minister contact. But I would say there was a fundamental reluctance on the part of New Zealand government through that period to make meaningful change and really engage in the issues".
} 
communication and influence into Canberra and business offices throughout Australia, whilst counteracting asymmetry by building relationships, respect and trust at the elite level. It has also allowed New Zealanders to assert a greater boldness and maturity in their interaction with their Australian counterparts. In particular the ANZLF has generated more contact between not only non-officials but also officials and ministers on both sides of the Tasman, which in some instances has contributed to more familiarised and intimate personal rapport. It is notable that John Key, Kevin Rudd and several ministers from their parties, were ANZLF participants while in opposition. Key's reported (but subsequently short-lived) "mateship" with Kevin Rudd was partly developed through the Forum and contributed to the warmest period in trans-Tasman relations since the ANZLF began.

A large part of enhancing state capabilities is creating a supportive constituency of important actors through the building of personal and business relationships. The psychological factor of familiarity and development of interpersonal relationships and business networking should not be underestimated. The ANZLF is an example of how cooperative behaviour is learned, perceptions and attitudes are changed, and trust is built. For instance, an Australian businessman and regular ANZLF participant noted:

\begin{abstract}
"I am more an advocate of the single economic market and of the opportunities of collaboration between Australia and New Zealand than I would otherwise have been, because of the experience and increased knowledge that the Forum has brought. So my desire to promote the two together is certainly heightened because of the Forum". 405
\end{abstract}

Nonetheless, the ANZLF has not lived up to everyone's expectations. Whilst the diplomatic aim of the ANZLF has been relatively successful, ${ }^{406}$ the Forum's declaration to “...interact with government and with broader business and union interests and the community, to help progress complex policy issues", has not, in the opinion of some participants, been achieved, resulting in attrition. Impatience for greater and swifter integration from some non-official participants indicated a sense of urgency that the ANZLF was losing credibility as a worthwhile and effective event.

Far from Margaret Jackson's stance at the 2004 Forum that called for one process

\footnotetext{
405 Australian business executive. Interview conducted August 2010.

406 To foster and strengthen the relationship at a number of levels through non-official debate and dialogue, through high-level networking, and through information and idea exchange in matters of mutual and strategic importance.
} 
and one umpire, the ANZLF has modified its position. While the more substantive SEM ideas that make a seamless business environment possible lie on the horizon, the ANZLF has largely accepted the status quo by softening its demands. After several meetings it accepted government policy and piecemeal progress, at times by compromising on its initial drive for an independent and alternative agenda for change. Failure by the Forum to produce a number of solid outcomes that were proposed at the earlier meetings suggests that the ANZLF process does not have a great deal of influence in agenda setting or the policing of policy direction. It would therefore be an overstatement to consider the Forum a policy community. When a group lacks resources (or at least is unwilling to invest) and a coherent strategy, its membership is unstable, where contact between state and non-governmental actors fluctuates in frequency, and the relationship verges on consultation rather than negotiation or decision-making, the notion of a policy community appears remarkably thin. ${ }^{407}$ To articulate a bolder or alternative vision would require the engagement of business and others forming independent organisations, such as reviving and modernising a trans-Tasman Business Council for instance. ${ }^{408}$

On the whole, the event has, over several meetings, developed a greater consensus on SEM and integration related issues, yet governments continue to dominate the exchange. Therefore, it also seems evident that the limited potential and actual activities of the ANZLF cast a long shadow over any claims to genuine multilevel governance in a trans-Tasman context. It does, however, demonstrate the potential for a wider community to agree on common goals, and in some cases work proactively towards them. Moreover, it shows the potential for informal diplomacy to create the conversations that give rise to shared norms. By providing this platform for non-state engagement, political credibility can be strengthened by the endorsement of key stakeholders on specific initiatives, which in turn might then be regarded as legitimate by the media and public.

If the underlying role of the ANZLF in the trans-Tasman relationship is to build relationships and a consensus, the value of the ANZLF is also in the dialogue. The topical issues discussed at the ANZLF have changed over six meetings, and there was a different quality of conversation in 2009 from that which took place in 2004. Discussions on

\footnotetext{
407 Demir, Tansu and Miller, Hugh T. "Policy Communities" in Frank Fischer, Gerald J Miller and Mara S. Sidney (eds.) Handbook of Public Policy Analysis, Theory, Politics, and Method. (CRC Press. London 2007) pp. 137-146.

408 Alternatively, establishing a third track in the bilateral relationship to coincide with the ANZLF and include younger alumni/persons, for example, university post-graduates, young Maori, Koori, Torres Strait and Pacific up-and-coming leaders, the youth political party wings, and aspiring entrepreneurs, would add a new dimension and dialogue to the future of the relationship.
} 
defence have transformed from heated and contentious dialogue to conversations around inter-operability and joint combat forces. Conversations on a common border and developing shared solutions on issues such as clean energy and food, climate change and scientific challenges have all added impetus to a shared consensus on economic and institutional integration. The crucial shift away from an introspective dialogue to an outward looking one is of significant value to the relationship itself. It might not constitute a paradigm shift or articulate a longer term vision, but it does demonstrate that a regular meeting of elites can indirectly encourage policy convergence, promote uniformity and smooth over irritants in the relationship.

Clearly the trans-Tasman economic relationship is at a different level of maturity than previous decades, and both countries are paying more attention to each other now than ever before. Without discounting periods of inertia and low activity, the annual focus on the trans-Tasman relationship has helped build policy convergence, and the Forum's working groups have contributed to this alignment. Leaders of important regulatory bodies who have attended the ANZLF meetings have indicated that the ANZLF gave impetus to a number of significant reforms. The relationship between elites from diverse corporate, political, union and academic backgrounds has been strengthened, whilst eroding a great deal of resentment and latent suspicion that existed among some. This has been evident in the growing collegiality that has been developed through several meetings that has seen delegations shift from focusing on national agendas to working collectively with a greater degree of trust. The Australia New Zealand Leadership Forum has not been the only factor that has propelled closer trans-Tasman political and economic ties over the last decade, but it has been an important, if underappreciated, part of that process. 


\section{Appendices}

Appendix One - List of interviewees

\section{Australian Participants}

Rowan Callick - Asia-Pacific Editor. The Australian. Telephone interview conducted 1 December 2010.

Phil Clark AM - Advisory Council JP Morgan. Education Investment Fund. Personal interview conducted in Sydney 12 August 2010.

Prof. Adrienne Clarke - Laureate Professor School of Botany, Melbourne University. Telephone interview conducted 3 August 2010.

Bob Cotton - Former Australian High Commissioner to New Zealand. Telephone interview conducted 17 November 2010.

Dr. Bob Edgar

- Senior Managing Director ANZ Banking Group. Telephone interview conducted 23 August 2010.

Prof. Allan Fels AO - Dean of Australia New Zealand School of Government. Telephone interview conducted 23 September 2010.

Dr Allan Hawke $\quad$ - Former Australian High Commissioner to New Zealand. Personal interview conducted in Canberra 19 August 2010.

Prof. Andrea Hull AO - Director Victorian College of the Arts. Telephone interview conducted 13 August 2010.

Katie Lahey

- Chief Executive Officer Business Council of Australia. Telephone interview conducted 22 September 2010.

Rod McGeoch AM - Chairperson Corrs, Chamber Westgarth. Skycity. Personal interview conducted in Sydney 10 August 2010.

Bruce Morgan

- Chairperson PriceWaterhouseCoopers. Personal interview conducted in Sydney 12 August 2010.

Sir Ralph Norris $\quad$ - Chief Executive Officer Commonwealth Bank of Australia. Telephone interview conducted 26 August 2010.

Geoff Ricketts* - Chairperson Lion Nathan. Telephone interview conducted 27 August 2010.

James Strong

- Chairperson Insurance Australia Group. Personal interview conducted in Sydney 10 August 2010.

John Weiss

- Chief Executive Officer Trans-Tasman Business Circle.

Personal interview conducted in Sydney 9 August 2010. 
Prof. Michael Wesley - Executive Director Lowy Institute. Personal interview conducted in Sydney 9 August 2010.

Prof. Hugh White - Head of the Strategic and Defence Studies Centre. Australian National University. Personal interview conducted in Canberra 17 August 2010.

* Served on both delegations

\section{Anonymous:}

Two Australian Department of Foreign Affairs and Trade officials. Interviews conducted in Canberra 18 August 2010 and by telephone 13 September 2010.

Two business leaders - Personal interviews conducted on 9 and 10 August 2010.

One academic participant. - Telephone interview conducted 1 September 2010.

\section{New Zealand Participants}

John Allen

Peter Conway

Jane Diplock AO

Martyn Dunne

Brian Fallow

Sir Frank Holmes

Stephen Jacobi

Jonathan Ling

Andrew Little
- Chief Executive Officer and Secretary of New Zealand Ministry of Foreign Affairs and Trade. Telephone interview conducted 1 October 2009.

- Secretary New Zealand Council of Trade Unions. Personal interview conducted in Wellington 6 May 2010.

- Chairperson New Zealand Securities Commission. Personal interview conducted in Wellington 13 September 2010.

- Customs Comptroller New Zealand Custom Services. Personal interview conducted in Wellington 28 July 2010.

- Economics Editor the New Zealand Herald. Personal interview conducted in Wellington 27 May 2010.

- Emeritus Professor Victoria Institute of Policy Studies. Personal interview conducted in Wellington 21 June 2010.

- Executive Director New Zealand International Business Forum. Personal interview conducted in Napier 29 April 2010.

- Chief Executive Officer Fletcher Building Ltd. Telephone interview conducted 5 August 2010.

- National Secretary Engineering, Printing and Manufacturing Union. Personal interview conducted in Wellington 4 May 2010. 
Kerry McDonald - Former Chairperson Bank of New Zealand. Company Director and Advisor. Personal interview conducted in Wellington 24 May 2010.

Simon Murdoch - Former Chief Executive Officer and Secretary of the New Zealand Ministry of Foreign Affairs and Trade. Personal interview conducted in Wellington 14 May 2010.

Phil O’Reilly

- Chief Executive Officer Business New Zealand. Personal interview conducted 24 June 2010.

Fran O'Sullivan $\quad$ - The New Zealand Herald. Informal interview conducted in Wellington October 2009.

Dr Ross Patterson - Former President of the Australia New Zealand Business Council. Telecommunications Commissioner. New Zealand Commerce Commission. Personal interview conducted in Wellington 7 September 2010.

Rt. Hon. Winston Peters - Former Minister for Foreign Affairs and Trade. Personal interview conducted in Auckland 28 June 2010.

John Shewan

- Chairperson PriceWaterhouseCoopers. Personal interview conducted in Wellington conducted 25 September 2009.

Ralph Waters - Chairperson. Fletcher Building Ltd. Telephone interview conducted 4 June 2010.

Ross Wilson - Former President of the New Zealand Council of Trade Unions. Personal interview conducted in Wellington 28 May 2010 .

\section{Anonymous:}

New Zealand Ministry of Foreign Affairs and Trade official - Personal interview conducted in Wellington 9 August 2009.

Three business leaders. - Personal interviews conducted on 10 April and 3 and 18 June 2010.

Two academics participants - Personal interview conducted and telephone interview conducted 10 April and 3 June 2010.

In addition, information was derived from private correspondence with Hon. Simon Upton

17 November 2010 and an anonymous Australian participant 20 June 2010. 


\section{Non- ANZLF Participants}

Keith Locke

- Personal Interview conducted in Wellington 23 November 2010.

Former personal assistant to a co-Chair - Anonymous interview conducted 2 June 2010.

Discussions in relation to the Australia New Zealand Business Council:

John Jenner

- Former Executive Director Australia New Zealand Business

Council. Informal telephone interview conducted 15 July 2010.

Ross Patterson - As above.

Peter Shirtcliffe $\quad$ - Former Chairperson Australia New Zealand Business Council. Informal telephone interview conducted 5 July 2010.

Hon. Jim Sutton - Minister for Trade Negotiations 1999 to 2005, Minister of Agriculture 1999 to 2005. Personal interview conducted in Wellington 6 July 2010.

Ethics Approval No. 17579 
Appendix Two - Standard questions asked of every participant.

On what basis were you invited to the ANZLF? Were you known to the co-Chair?

Did you have any involvement in the working groups? If so, was that working group successful in achieving its objectives?

Do you think the ANZLF has been influential in changing the views of yourself, other participants and/or governments?

How could the ANZLF's objectives be better advanced, or are the current arrangements satisfactory?

What have been the key differences in respective meetings - how have the dynamics changed?

In your view, what is the value of the ANZLF? What does it add to the trans-Tasman relationship that was not there already?

Do you think the Forum has facilitated the broadening of trans-Tasman networks and people-to-people relations?

Has there been a change in the way the participants interact? Has it become more or less collegial?

Did you feel you were on a distinctly national delegation, or representing your profession?

What success stories can the ANZLF claim? 
Appendix Three - Regular Attendees (based on attendance at all 2004-2009 meetings)

The Australian delegation has generally consisted of two-thirds business and industry representatives, with a progressive strengthening of political delegates that came to dominate the 2008 Forum in Wellington and 2009 Forum in Sydney. Regular Australian delegates at the ANZLF have included: Head of Group Security Qantas Geoff Askew, Australian Council of Trade Unions President Sharon Burrow, Minter Ellison - JP Morgan Advisory Council Phil Clark AM, ANZ Banking Group Chief Operating Director Dr Bob Edgar, Australia New Zealand School of Government Dean Allan Fels AO Victorian College of the Arts Prof Andrea Hull AO, Business Council of Australia Chief Executive Katie Lahey, Sky City Entertainment Group Chairperson Rod McGeoch AM, PriceWaterhouseCoopers Chairperson Bruce Morgan, Department of Treasury, Executive Director Markets Group Jim Murphy, Australian Industry Group Chief Executive Heather Ridout.

New Zealand, on the other hand, has had a longer list of regular participants which have generally consisted of half business delegates, and the other half extending from government departments, policy institutes, and academic and cultural leaders. Long-serving delegates at each Forum have included: Auckland Chamber of Commerce Chief Executive Michael Barnett, Reserve Bank of New Zealand Governor Dr Allan Bollard, Steel and Tube Holdings Ltd Chief Executive Officer Nick Calavrias, Securities Commission Chairperson Jane Diplock AO, New Zealand Customs Comptroller Martyn Dunne, former Minister of Foreign Affairs and Minister for Trade Hon. Phil Goff, Political Journalist and Managing Director the Hugo Group Colin James, Trans-Tasman Business Circle Hon. Jim McLay, No 8 Ventures Managing Partner Jenny Morel, former Secretary of Foreign Affairs and Trade Simon Murdoch, Air New Zealand Chairperson John Palmer, New Zealand Commerce Commission and Kiwirail Chairperson Paula Rebstock, Price Waterhouse Coopers Chairperson John Shewan, Fletcher Building Chief Executive Ralph Waters, New Zealand Council of Trade Unions President Ross Wilson. 
Appendix Four - Challenges to improve trans-Tasman labour market outcomes Former CTU President Ross Wilson stated at the 2005 ANZLF that Labour challenges include:

- Extending existing co-operation between New Zealand and Australian on initiatives which have the potential to increase productivity.

- At officials level to reduce the extent of duplication and inconsistency between the regulatory regimes that apply in each country (for example, the decision to establish Food Standards Australia New Zealand).

- At industry and enterprise level to develop processes which facilitate the transfer of best practice and smart ideas.

- Encouraging industries to take a trans-Tasman perspective on skill needs and skill development requirements. This would recognise the trans-Tasman nature of the labour market, and recognise that taking steps to meet the skill needs in a particular state in Australia, or within New Zealand, may not lead to the best use of training resources.

- Encouraging Government agencies to also adopt a trans-Tasman approach to their work on identifying skill needs and skill development requirements. While there is some co-operation and information sharing between Australian federal agencies and there New Zealand counterparts, there may be benefits if they moved to a level of co-operation that extends beyond information sharing into joint decision making.

- Developing a common system for recognising skills within New Zealand and all Australian states. This will allow labour to move more easily to those areas where it is in greatest demand and increase the potential for labour specialisation, which can increase labour productivity. Currently, it can be difficult to move between New Zealand and all states of Australia due to different skill recognition regimes applying in each state.

Ross Wilson. "The Australasian labour market: in an Asian Context". Speech to the Australia New Zealand Leadership Forum, 29-30 April 2005. 


\section{Appendix Five - Trans-Tasman Outcomes Implementation Group}

According to the TTOIG website, the group comprises of representatives of the Australian Treasury and New Zealand Ministry of Economic Development (as joint chairs), the Australian Departments of: Prime Minister and Cabinet, Foreign Affairs and Trade, and Finance and Deregulation; and the New Zealand Department of Prime Minister and Cabinet, Ministry of Foreign Affairs and Trade, and Treasury. Representatives from other relevant departments may be invited to join the group as required. The initial co-Chairs are Geoff Miller, General Manager, Corporations and Financial Services Division, the Treasury (Australia), and Yvonne Lucas, Director, Ministry of Economic Development (New Zealand). Meetings are held four times per year, alternately in Australia and New Zealand. The costs of participation in the Group are met by the member departments. The group has the capacity to establish sub-groups (if needed for specific issues).

www.treasury.gov.au/ttoig/content/tor.asp (Accessed: 14/01/11) 


\section{Bibliography}

Agha, Hussein; Feldman, Shai; Khalidi, Ahmad and Schiff, Zeev. Track 2 Diplomacy: Lessons from the Middle East (MIT Press. East Cambridge 2003).

Allen, John and McGeoch, Rod. "Submission to the Australia's Future Tax System Review". 25 September 2008.

Ansley, Greg. "A united front across the Tasman”. The New Zealand Herald. 12 February 2011.

Ansley, Greg. "Common border high on PMs list". The New Zealand Herald. 3 March 2009.

Ansley, Greg. "NZ and Australia: Standing together, and apart". The New Zealand Herald. 27 March 2003.

Australian American Leadership Dialogue. "Young Leadership Dialogue". www.aald.org/index/index/page/our_programs/catid/59 (Accessed: 09/11/10).

Australia Foreign Affairs Review. Canberra. February 1983.

Australian Broadcasting Corporation. "Clark angered by Ansett workers' action". Insiders. 16 September 2001.

Australian Department of Foreign Affairs and Trade. "New Zealand Country Brief". www.dfat.gov.au/geo/new_zealand/nz_country_brief.html (Accessed: 20/02/11).

Australia New Zealand Business Council. "Submission Number 12: Australia-New Zealand Business Council Inc. July 2004". New Zealand Department of Economic Development. Section 64 Review and Schedule 3 Investigation into Unbundling the Local Loop Network and the Fixed Public Data Network. Submission to the Minister of Communications. February 2004. www.med.govt.nz/templates/Page 2504.aspx (Accessed: 12/12/2010).

Australia New Zealand Business Council. "The Future of CER: A trans-Tasman Borderless Market". Joint Submission to Ministers 2000.

Australian Treasury. "Ministers Enhance the trans-Tasman Business Environment". Joint Press Conference". Melbourne. 30 January 2004. www.treasurer.gov.au/DisplayD ocs.aspx?pageID= \&doc=transcripts/2004/012.htm\&min=phc (Accessed: 14/12/10).

Ba, Alice D. "Who's socializing whom? Complex Engagement in Sino-ASEAN Relations". The Pacific Review. Vol. 19. No. 2. June 2006.

Bache, Ian and Flinders, Matthew V. Multi-level Governance (Oxford University Press. New York 2004).

Ball, Desmond; Milner, Anthony and Taylor, Brendan. "Mapping Track II Institutions in New Zealand, Australia and the Asian Region". An Independent Study Submitted to the Asia New Zealand Foundation. 2005.

Ball, Desmond; Milner, Anthony and Taylor, Brendan. "Track 2 Diplomacy in Asia: Australian and New Zealand Engagement”. Strategic and Defence Studies Centre. The Australian National University Canberra 2006.

Ball, Desmond; Milner, Anthony and Taylor, Brendan. "Track 2 Security Dialogue in the Asia-Pacific: Reflections and Future Directions". Asian Security. Vol. 2. No. 3. 2006.

Barry, Michael and Wailes, Nick. "Revisiting the Australia-New Zealand Comparison". New Zealand Journal of Employment Relations. Vol. 17. No. 3. 2005.

Bedford, Jackie. "Investment Protocol to be Formalised During Gillard Visit". Newsroom. 14 February 2011.

Belich, James. Paradise Reforged: a history of New Zealanders from the 1880s to the year 2000 (University of Hawaii Press. Honolulu 2001).

Bell, Stephen; Hindmoor, Andrew and Mols, Frank. "Persuasion as Governance: A state-relational perspective". Public Administration. Vol. 99. No. 3. 2010.

Bell, Stephen and Hindmoor, Andrew. Rethinking Governance: The Centrality of the State in Modern Society (Cambridge University Press. Oxford 2005).

Bollard, Alan and Gaitanos, Sarah. Crisis: One Central Bank Governor and the Global Financial Collapse Crisis (Auckland University Press. Auckland 2010).

Broman, Matilda. "Taking Advantage of Institutional Possibilities and Network Opportunities". 
Lund Political Studies. No. 152. 2008.

Brown, Bruce (ed.) New Zealand-Australia Relations: Where are we going? (New Zealand Institute of International Affairs. Wellington 2001).

Burchill, Scott. Australia's International Relations: particular, common and universal interests (Australian Institute of International Affairs. Deakin University. Melbourne 1994).

Butler, D.E. The Study of Political Behaviour (Hutchinson Publishing. London 1958).

Callick, Rowan. "Opposite Attracts in renewed trans-Tasman friendship". The Australian. 31 August 2009.

Campaign Against Foreign Control of Aotearoa."Inquiry into New Zealand's Economic and Trade Relationship with Australia. Foreign Affairs, Defence and Trade Select Committee. Submission from the Campaign Against Foreign Control of Aotearoa". 6 July 2000. www.canterbury.cyberplace.org.nz/community/CAFCA/publications/Trade/CERsubmissio n.pdf (Accessed: 10/01/11).

Capie, David. "When does track two matter? Structure, agency and Asian regionalism". Review of International Political Economy. Vol. 17. No. 2. 2010.

Capie, David and Evans, Paul. The Asia-Pacific Lexicon. Second Edition (ISEAS Publishing. Singapore 2007).

Catley, Bob (ed.) New Zealand-Australia Relations: Moving Together or Drifting Apart? (Dark Horse Publishing. Wellington 2002).

Catley, Bob. Waltzing with Matilda. Should New Zealand join Australia? (Dark Horse Publishing. Wellington 2001).

Chatham House website. "The Chatham House Rule". www.chathamhouse.org/about-us/chathamhouserule (Accessed: 10/12/10).

Checkel, Jeffrey. "Why comply? Social learning and European Identity Change". International Organization. Vol. 55. No. 3. 2001.

Clark, Helen. "Speech to Parliament. 27 April 1982”. Hansard. 6 April - 4 May. Vol. 443.

Cook, Malcolm. "Standing together, in Single File: Australian views of New Zealand and Asia". Outlook 13. Report for the Asia New Zealand Foundation and the Lowy Institute.

Costello, Peter. "Australia and New Zealand: Siblings with a Common Heritage and a Shared Future". Speech to the Auckland Chamber of Commerce on the occasion of the 20th Anniversary of the Closer Economic Relations Agreement between Australia and New Zealand. 20 February 2003.

Costello, Peter and Cullen, Michael. "Joint Press Conference". 19 February 2003.

Crean, Simon. "Australia New Zealand Leadership Forum". Ministerial Statement to the House. 16 June 2008.

Cullen, Michael. "Address to NZ Gala Day Dinner". 9 March 2005. www.beehive.govt.nz/node/22396 (Accessed: 01/12/10).

Cullen, Michael. "Parliamentary Debate". Hansard. 6 April 2006. Vol. 630.

Cullen, Michael. "Speech to the Australia New Zealand Leadership Forum". 13 June 2008.

Dalziel, Lianne. Where To From Here? Launch of the NZAC. New Zealand Government Website. 10 October 2008. www.feeds.beehive.govt.nz/speech/where+here+launch+nzac (Accessed: 17/12/10).

Davidson, William D. and Montville, Joseph V. "Foreign Policy According to Freud". Foreign Policy. No. 45. Winter 1981-1982.

Deane, Roderick. "Comments on a Single Economic Market for Australia and New Zealand". www.independenteconomics.com/assets/papers/anzleadershipforum.pdf (Accessed: 09/08/10).

Demir, Tansu and Miller, Hugh T. "Policy Communities" in Frank Fischer, Gerald J Miller and Mara S. Sidney (eds.) Handbook of Public Policy Analysis, Theory, Politics, and Methods (CRC Press. London 2007). 
Espiner, Guyon. "Q and A". Television New Zealand. 6 September 2009.

Evans, M. and Davis, J. "Understanding policy transfer: a multi-level, multidisciplinary perspective". Public Administration. Vol. 77. No. 2. 1999.

Fallow, Brian. "Big business happy to take backseat". The New Zealand Herald. 16 June 2008.

Fallow, Brian. "Leadership Forum fails to tackle the big issues". The New Zealand Herald .7 May 2006.

Fensom, Anthony. "Rudd's Asia-Pacific plan lost at sea?" The Diplomat. 31 May 2010.

Fukushima, Kiki. A Fate of Regionalism in East Asia and Northeast Asia. A View from Tokyo (National Institute for Research Advancement. Tokyo 2006).

Gamlen, Alan. "Engaging Asia: the role of the Diaspora". Outlook 5. Asia New Zealand Foundation. 2011.

Gillard, Julia. "Priorities for the Australian Government". Speech to the Australia New Zealand Leadership Forum. Wellington. 13 June 2008.

Gilpin, Robert. "The Politics of Transnational Economic Relations." in R. O. Keohane and J. S. J. Nye (eds.) Transnational Relations and World Politics (Harvard University Press. Cambridge, MA 1972).

Glaser, Barney and Strauss, Anselm. The Discovery of Grounded Theory: Strategies for Qualitative Research (Aldine de Gruyter. New York 1967).

Global Research Alliance on Agricultural Greenhouse Gases website. www.globalresearchalliance.org/ (Accessed: 23/01/11).

Goldfinch, Shaun. Remaking New Zealand and Australian Economic Policy. Ideas, Institutions and Policy Communities (Victoria University Press. Wellington 2000).

Goldfinch, Shaun. "The Old Boys' Network? Social Ties and Policy Consensus amongst Australian and New Zealand Economic Policy Elites". Policy and Society. Vol. 21. No. 2. 2002.

Goff, Phil. "The Trans-Tasman Relationship. A New Zealand Perspective". Australian Review of Public Affairs. Vol. 2. No. 1. 2001.

Gore-Booth, Lord Paul. "Historic Skills and New Tasks: The Diplomatic Service in the Seventies". Royal Institute of International Affairs. Vol. 46. No. 4. 1970.

Griffin, Peter and O'Sullivan, Fran. "Australia presses NZ to break Telecom monopoly". The New Zealand Herald. 14 May 2004.

Gyngell, Allan; Skilling, David and Thirlwell Mark. "Australia and New Zealand in a Globalising World". Paper presented at the Fourth Annual Australia New Zealand Leadership Forum. Sydney 23-24 April 2007.

Haas, Peter M. "Epistemic Communities and International Policy Coordination". International Organization. Vol. 46. No. 1. 1992.

Harrigan, Nicholas and Goldfinch, Shaun. “A Trans-Tasman Business Elite?” Journal of Sociology. Vol. 43. No. 4. 2007.

Harris, Stuart. "Policy Networks and Economic Cooperation: Policy Coordination in the Asia-Pacific Region". The Pacific Review. Vol. 17. No. 4. 1994.

Hawke, Allan. "Comparing OZ apples with NZ pears". The New Zealand Herald. 7 December 2005.

Hawke, Allan. "The High Commissioner". Speech given to the New Zealand Institute of International Affairs. Wellington. 12 February 2004 www.victoria.ac.nz/nziia/assets/talks/wn/Hawke-speech.doc (Accessed: 21/08/10).

Hawke, Allan. "Neighbours, friends and all too often rivals". Address to the New Zealand Institute of International Affairs. Wellington. The New Zealand Herald. 8 December 2005.

Hempenstall, Peter. "The Australia New Zealand Leadership Forums". Canterbury University. Christchurch, 2006. www.nzac.canterbury.ac.nz/docs/leadershipforumsMar07.pdf (Accessed: 27/07/10).

Hempenstall, Peter and Mein Smith, Philippa. "Australia's Trade and Investment Relations under the Australia-New Zealand Closer Economic Relations Trade Agreement”. Parliament of Australia, Joint Standing Committee on Foreign Affairs, Defence and Trade, Trade Sub-Committee. Submission No. 15. 2006. 
Higley, John, Deacon, Desley and Smart, Don. Elites in Australia (Routledge. London 1979).

Hocking, Brian. "Multi-Stakeholder Diplomacy: foundations, forms, functions and frustrations". (Diplo Foundation. Malta 2005).

Hoffman, Aaron. "A Conceptualization of Trust in International Relations". European Journal of International Relations. Vol. 8. No. 3. 2002.

Holmes, Sir Frank. "An Australia-New Zealand Economic Community?" Institute of Policy Studies Newsletter. No. 71. November 2002.

Holmes, Sir Frank. Policy Paper No 14: An ANZAC Union? Institute of Policy Studies. Wellington 2002.

Holmes, Sir Frank. "The Australia New Zealand Leadership Forum. Reflections on its Proceedings". 17 August 2004. www.ips.ac.nz/events/downloads/Leadership-Forum.doc. (Accessed: 16/12/10).

Holmes, Sir Frank. Policy Paper No 17: The Rocky Road to CER. Institute of Policy Studies. Wellington 2003.

Holten, Robert J. Global Networks (Palgrave MacMillan. New York 2008).

Hooghe, Liesbet and Marks, Gary. Multi-Level Governance and European Integration (Rowman and Littlefield. Boulder 2001).

Jackson, Margaret. "Address by Margaret Jackson to the Trans-Tasman Business Circle". 12 May 2004.

Jackson, Margaret and McDonald, Kerry. "The Australia New Zealand Leadership Forum”. Communiqué. 15 May 2004.

James, Colin. "Some movement in the glacier". New Zealand Management. October 2003.

James, Colin. "Some thoughts on Recent Seminars on the Australia-New Zealand Relationship". Institute of Policy Studies Newsletter. No. 71. November 2002.

James, Colin. "Stronger together in an uncertain world". The Press. 8 August 2009.

James, Colin. "The Anzac deal: just how deep might it go?" The Dominion Post. 26 April 2010.

James, Colin. "Three-Step with Matilda: Trans-Tasman Relations" in Roderic Alley (ed.) New Zealand in World Affairs IV 1990-2005 (Victoria University Press. Wellington 2007).

James, Colin. "TransTasman deals open door to world". The New Zealand Herald. 13 September 2008.

James, Colin. "Two countries diverging”. The New Zealand Herald. 23 October 2001.

Jessop, Bob. "Multi-level Governance and Multi-level Meta-governance" in Ian Bache and Matthew Flinders (eds.) Multi-level Governance (Oxford University Press. New York 2004).

Johnston, Alistair Iain. "Socialization in International Institutions. The ASEAN Way and International Relations Theory" in John Ikenberry and Michael Mastanduno (eds.) International Relations Theory and the Asia-Pacific (Columbia University Press. New York 2003).

Jones, D. M. and Smith, M.L.R. "Making Process not Progress ASEAN and the Evolving East Asian Regional Order". International Security. Vol. 32. No. 1. 2007.

Jones, Peter. "Filling a critical gap, or just wasting time? Track Two diplomacy and regional security in the Middle East". Arms Control in the Middle East . No. 2. 2008.

Jönsson, Christer and Langhorne, Richard (eds.) Diplomacy. Vol. 1 (Sage Publication. London 2004).

Josselin, Daphne and Wallace, William (eds.) Non-State Actors in World Politics (Palgrave. New York 2001).

Kaiser, Wolfram; Leucht, Brigitte, and Gehler, Michael. "Transnational Networks in European Integration Governance" in Kaiser, Leucht and Gehler (eds.) Transnational Networks in Regional Integration: Governing Europe (Palgrave Macmillan. Basingstoke 2010).

Kane, E. J. "Confronting divergent interests in cross-country regulatory arrangements". Reserve Bank Bulletin. Vol. 69. No. 2. 2006.

Katsumata, H. "The Role of ASEAN Institutes of Strategic and International Studies in Developing Security Operations in the Asia-Pacific". Asian Journal of Political Science. Vol. 11. No. 3. 2003. 
Kavanagh, D. “Why Political Science needs History?” Political Studies. Vol. 39. No. 3. 1991.

Kaye, Dalia. Rethinking Track Two Diplomacy. Netherlands Institute of International Relations. Clingendael Diplomacy Papers. No. 3. The Hague 2005.

Kedgley, Sue. "Address in Reply". The New Zealand Green Party. 3 September 2002.

Key, John and Rudd, Kevin. "Joint Statement of Intent: Single Economic Market Outcomes Framework". 20 August 2009.

King, Annette. "Therapeutics Products and Medicines Bill on hold". Press Release. 16 July, 2007.

Korten, David C. When Corporations Rule the World (Earthscan Publications. London 1995).

Kraft, Herman. "The Autonomy Dilemma of Track Two Diplomacy in Southeast Asia". Security Dialogue. Vol. 31. No. 3. 2000.

Kraft, Herman. "Track Three Diplomacy and Human Rights in Southeast Asia". Global Networks: A Journal of Transnational Affairs. Vol. 2, No. 1. 2002.

Kurbalija, Jovan. Modern Diplomacy (The Mediterranean Academy of Diplomacy. Athens 1998).

Lacher, H. "Putting the state in its place: the critique of state-centrism and its limits". Review of International Studies. Vol. 29. No. 4. 2003.

Longdin, Louise. "Parallel Importing Post Trips: Convergence and Divergence in Australia and New Zealand". The International and Comparative Law Quarterly. Vol. 50. No. 1. 2001.

Lord, Michael D. "Constituency building as the foundation for political strategy". Management Executive. Vol. 17. No.1. 2003.

Lloyd, Peter. The Future of CER: a single economic market for Australia and New Zealand (Victoria University Press. Wellington 1991).

Lloyd, Peter. "The Future of Trans-Tasman Closer Economic Relations". Agenda. Vol. 2. 1995.

Makito, Noda. "The Role of Nonstate Actors in Building an ASEAN Community" in Sekiguchi Sueo and Noda Makito (eds.) Road to ASEAN-10: Japanese Perspectives on Economic Integration (Japan Center for International Exchange. Tokyo 1999).

Marks, Gary and Hooghe, Liesbet. "European Integration from the 1980s: statecentric vs. multilevel governance". Journal of Common Market Studies. Vol. 34. No. 3. 1996.

Marsh, D. and Rhodes, R. A. W. Policy Networks in British Government (Clarendon Press. Oxford1992).

Max Bowden's BusinessSense. “Gillard's Accession Creates Uncertainty for Trans Tasman Relations". The Main Report. 5 July 2010.

McDonald, Kerry. "Development of a Single Economic Market and Common Border with Australia". Communiqué. 28 July 2005.

McGeoch, Rod. "Speech to the Trans-Tasman Business Circle". Auckland. 15 February 2011.

McKay, Pia ."Young Leader reflects on Track II trip to India and Malaysia". Asia New Zealand Foundation. www.asianz.org.nz/our-work/young-leaders/out-and-about/track2 (Accessed: $15 / 01 / 11)$.

Melissen, Jan. Innovation in Diplomatic Practice (Palgrave. New York 1999).

Mein Smith, Philippa. "Did Muldoon really 'go too slowly' with CER?" New Zealand Journal of History. Vol. 14. No. 2. 2007.

Mein Smith, Philippa; Hempenstall, Peter and Goldfinch, Shaun. Remaking the Tasman World (Canterbury University Press. Christchurch 2008).

Montville, Joseph. "Track Two Diplomacy: The Arrow and the Olive Branch." in V. Volkan; J. Montville and D. Julius (eds.) The Psychodynamics of International Relations, Volume 2: Unofficial Diplomacy at Work (Lexington Books. Lexington 1990).

Moravcsik, Andrew. "Taking Preferences Seriously: A Liberal Theory of International Politics". International Organization. Vol. 51. No. 4. 1997.

Moravcsik, Andrew. "Liberal Intergovernmentalism and Integration: A Rejoinder". Journal of Common Market Studies. Vol. 33. No. 4. 1995.

Morgenthau, Hans J. Politics Among Nations: The Struggle for Power and Peace (Alfred A. Knopf. New York 1978). 
Naidoo, Sagaren. "The Role of Track Two Diplomacy in the Democratic Republic of Congo". African Journal on Conflict Resolution. Vol. 1. No. 2. 2000.

Nan, Susan Allen. "Track 1 Diplomacy" in Guy Burgess and Heidi Burgess (eds.) Beyond Intractability (Conflict Research Consortium, University of Colorado. 2003).

Nan, Susan Allen. "Track One and a Half Diplomacy: Searching for Political Agreement in the Caucasus" in Fari Fitzduff and Cheyanne Church (eds.) NGOs at the Table: Strategies for Influencing Policies in Areas of Conflict (Rowman \& Littlefield. Lanham 2004).

National Business Review. "Work continues on single economic market". 3 June 2010.

New Zealand Foreign Affairs, Defence and Trade Committee. "Inquiry into New Zealand's Economic and Trade Relationship with Australia" (New Zealand Parliament. Wellington 2002).

New Zealand Government. "Government Response to the Report of the Foreign Affairs, Defence and Trade Committee into New Zealand's Economic and Trade relations with Australia". Tabled in Parliament on 25 September 2002. Courtesy of the New Zealand Parliamentary Library. Wellington.

New Zealand Institute of Economic Research. "Stepping towards a borderless market? The future of the trans-Tasman market. Report to the Australian New Zealand Business Council". New Zealand Institute of Economic Research. Wellington. August 2003.

New Zealand Listener. "2009 Power \& Influence List: Business \& Economic”. No. 3630. December 2009.

New Zealand Ministry of Foreign Affairs and Trade. Annual Report 2007/08. Wellington 2008.

New Zealand Ministry of Foreign Affairs and Trade. Bede Corry to John Allen. "Background Paper for 2008 Australia New Zealand Leadership Forum". 4 June 2008.

New Zealand Ministry of Foreign Affairs and Trade. The Australia - New Zealand Closer Economic Relationship (New Zealand Ministry of Foreign Affairs and Trade. Wellington 2005).

New Zealand Ministry of Foreign Affairs and Trade. "Australia: Political Links". www.mfat.govt.nz/Foreign-Relations/Australia/2-Political-links/index.php (Accessed: $12 / 01 / 11)$.

New Zealand Ministry of Foreign Affairs and Trade. The Single Economic Market Agenda www.mfat.govt.nz/Foreign-Relations/Australia/2-SEM/index.php (Accessed: 10/04/10).

New Zealand National Party. "Cullen's failure to front at forum a disgrace". Press Release. 6 April 2006.

New Zealand Securities Commission. 2010 Annual Report. Wellington 2010.

New Zealand Southern Cross. 13 February 1948.

Nicholson, Brendan. "Kiwi call to arms: PMs join forces to revive Anzac spirit". The Sydney Morning Herald. 21 August 2009.

Nicolson, Harold. Diplomacy (Oxford University Press. London 1963).

Nixon, Chris. CER: The Cornerstone of New Zealand's Trade Policy (New Zealand Institute of Economic Research. Wellington 2000).

O'Sullivan, Fran. "A forum that almost didn't happen". The New Zealand Herald. 14 June 2008.

O'Sullivan, Fran. "Allen appointment a new direction". The New Zealand Herald. 9 May 2009.

O'Sullivan, Fran. "ANZAC Spirit falters on the trade front". The New Zealand Herald. 25 April 2007.

O'Sullivan, Fran. “Australia snipes at NZ nuclear ban”. The New Zealand Herald. 13 May 2004.

O'Sullivan, Fran. "Big neighbour doesn't take NZ for granted”. The New Zealand Herald. 13 May 2004.

O’Sullivan, Fran. "Clark signals Rudd - Please ask next time". The New Zealand Herald. 14 June 2008.

O'Sullivan, Fran. "Crean pushes agenda on investment". The New Zealand Herald. 18 June 2008.

O'Sullivan, Fran. "Cullen's roars aren't going to serve him”. The New Zealand Herald. 11 April 2006.

O'Sullivan, Fran. "Cullens snub causes a to-do". The New Zealand Herald. 12 April 2006.

O'Sullivan, Fran. "Daunting challenge to feed the world". The New Zealand Herald. 7 April 2010.

O'Sullivan, Fran. "From Beach Barbie to Power Play". The New Zealand Herald. 28 April 2005. 
O'Sullivan, Fran. "Guest list a touchy topic at Leadership Forum". The New Zealand Herald. 26 April 2004.

O'Sullivan, Fran. "Let's see a real inquiry into the Telecom leak". The New Zealand Herald. 9 May 2006.

O'Sullivan, Fran. "NZ Inc set up to avert Aussie takeover at summit". The New Zealand Herald. 14 May 2004.

O'Sullivan, Fran. "New chance for ones who missed out". The New Zealand Herald. 26 May 2004.

O'Sullivan, Fran. "PM makes graffe on border idea". The New Zealand Herald. 18 May 2004.

O'Sullivan, Fran. "Politics back on the Agenda". The New Zealand Herald. 22 April 2007.

O'Sullivan, Fran. "Too many voices for single market”. The New Zealand Herald. 2 May 2005.

O'Sullivan, Fran. "Trans-Tasman single market looking likely". The New Zealand Herald. 26 May. 2004.

O'Sullivan, Fran. "Treasurers setting the pace". The New Zealand Herald. 2 February 2004.

O'Sullivan, Fran. "Tricky issues on transtasman agenda". The New Zealand Herald. 21 August 2009.

Parliament of the Commonwealth of Australia. Review of Australia - New Zealand Trade and Investment Relations: Coordination and Setting the Agenda. Joint Standing Committee on Foreign Affairs and Trade. Comments from P. Hooton, Assistance Secretary, Pacific Regional and New Zealand Branch. Australian Department of Foreign Affairs and Trade. Canberra. 2006.

Patman, Robert. "Globalisation and Trans-Tasman Relations: Integration or Divergence?" Australian Journal of International Affairs. Vol. 55. No. 3. 2001.

Peart, Mark. "Comment on Australia New Zealand Leadership Forum". New Zealand Management. Vol. 55. July 2008.

Peart, Mark. "Bridging Trans-Tasman Relationships - Leading the Leadership Movement". New Zealand Management. 1 October 2008.

Peterson, John. Policy Networks (Institute for Advanced Studies. Vienna 2004).

Peterson, J and O'Toole, L.J. "Federal governance in the US and the EU: A policy network perspective" in K. Nicolaidis and R. Howse (eds.) The Federal Vision: Legitimacy and Levels of Governance in the United States and the European Union (Oxford University Press. Oxford 2001).

Pigman, Geoffrey. "Making Room at the Negotiating Table: The Growth of Diplomacy between Nation-State Governments and Non-State Economic Entities". Diplomacy and Statecraft. Vol. 16. No. 2. 2005.

Prendergast, John Bernard ."Trade with Australia" in A.H. Lintock (ed.) Encyclopaedia of New Zealand 1966 (Wellington 1966).

PriceWaterhouseCoopers Survey. "Reshape Agility for tomorrow". 13th Annual Global CEO Survey 2009.

Rebstock, Paula. "Speech to Trans-Tasman Business Circle". 4 September 2006.

Rhodes, Rod. Understanding Governance: Policy Networks, Governance, Reflexivity and Accountability (Open University Press. Buckingham 1997).

Rosamond, Ben. Theories of European Integration (St. Martin's Press. New York 2000).

Sabatier, P. A and Jenkins-Smith, H.C. (eds.) Policy Change and Learning: An Advocacy Coalition Approach (Westview Press. Boulder 1993).

Saunders, Harold. "Officials and Citizens in International Relationships: The Dartmouth Conferences" in V. Volkan, J. Montville, and D. Julius (eds.) The Psychodynamics of International Relations, Volume 2: Unofficial Diplomacy at Work (Lexington Books. Lexington 1990).

Schiff, Amira. "Quasi Track-One Diplomacy: An Analysis of the Geneva Process in the Israeli-Palestinian Conflict". International Studies Perspectives. Vol. 11. No. 2. 2010.

Schouten, Hank. "CER pioneer attacks talk of curbing migration". The Dominion Post. 27 July 2010. 
Search for Common Ground Organisation. "Track One and a Half Diplomacy"

www.sfcg.org/resources/resources terms.html (Accessed: 15/01/11).

Shirtcliffe, Geof. "Seven Steps to Heaven or a step too far?" Chapman Trip Brief Counsel. 9 November 2009.

Skilling, David. "Competing and cooperating: Growing New Zealand's economic relationship with Australia". The New Zealand Institute. 22 March 2007.

Skogstad, Grace. "Policy Networks and Policy Communities: Conceptual Evolution and Governing Realities". Paper prepared for the workshop on "Canada's Contribution to Comparative Theorizing". Annual Meeting of the Canadian Political Science Association. University of Western Ontario. 2 June 2005.

Smellie, Pattrick. "Singapore-New Zealand deal a catalyst for wider regional trade agreements" Australian Financial Review. 1 September 2000.

Stone, Diane and Nesadurai, Helen E.S. "Networks, Second Track Diplomacy and Regional Cooperation: The Experience of Southeast Asian Think Tanks". Paper presented to the Inaugural Conference on Bridging Knowledge and Policy. The Global Development Network, Bonn, Germany, 5-8 December 1999.

Sutton, Jim and Vaile, Mark. "Joint Statement". 31 August 2000.

Sydney Morning Herald. "Air reforms grounded". 8 January 2011.

Sydney Morning Herald. "NZ, Australia should consider merger”. 6 December 2006.

Synder, Richard, and Bruck Henry W. Foreign Policy Decision-Making (Palgrave McMillan. New York 2002).

Tallberg, Jonas. Power of the Chair: Formal Leadership in International Cooperation (Stockholm University. Stockholm 2008).

Tapp, E.J. “Australia and New Zealand Relations 1900-1950”. The Australian Outlook. December 1951.

Taylor, Kevin. "Anzac dollar splits firms". The New Zealand Herald. 15 May 2004.

Television New Zealand. "Anzacs "close" but could be closer". 14 May 2004.

Television New Zealand. "Cullen calls forum a wailing wall". 6 April 2006.

The Age. "Helen Clark Frisked at Sydney Airport". 24 November 2003.

The Australian. "Melbourne Businessman Phil Scanlan named as our voice in New York". 11 December 2008.

The Dominion Post. "Bridging the Tasman". 12 May 2004.

The Dominion Post. "Once Were Mates, Now Rivals". 23 September 2003.

The New Zealand Herald. "Australia and NZ merger inevitable". 14 March 2010.

The New Zealand Herald. Editorial. "New Zealand business like branch of Australia". 30 March 2006.

The New Zealand Herald. "No freeloading on Defence, says Goff”. 17 May 2004.

The New Zealand Herald. "NZ likely to extend deposit guarantee scheme". 20 August 2009.

The New Zealand Herald. "Trans-Tasman single economic market: What's on the agenda for tomorrow's talks?"16 March 2004.

The Press. "Resurrection of ANZAC contingent mutually beneficial". 28 August 2009.

True, Jacqui and Devetak, Richard. "Diplomatic Divergence in the Antipodes: Globalisation, Foreign Policy and State Identity in Australia and New Zealand". Australian Journal of Political Science. Vol. 41. No. 2. 2006.

Upton, Simon. "Upton Online Diaspora”. 26 October 2002. www.arcadia.co.nz/uptononline/2002/october_26_2002.htm (Accessed: 12/12/10).

Upton, Simon “Upton Online Diaspora”. 28 October 2002. www.scoop.co.nz/stories/HL0210/S00188.htm (Accessed: 18/01/11).

Van der Bergh, Roeland. "Hostility to Aussie banks irks ANZ boss". The Dominion Post. 30 April 2010. 
Wallington, T., Lawrence, G. and Loechel, B. "Reflections on the Legitimacy of Regional Environmental Governance: Lessons from Australia's Experiment in Natural Resource Management". Journal of Environmental Policy and Planning. Vol. 10. No. 1. 2008.

Watkins, Tracy. "Envoy takes dig at Kiwi attitudes". The Dominion Post. 28 August 2004.

Wells, Nick. "Down-under Vs. world". The Counsel. Chapman Tripp. 18 July 2007.

Wells, Nick. "Closer to Canberra - The risk of banking on Australia for a fair deal". New Zealand Management. March 2005

Wilson, Ross. "The Australasian labour market: in an Asian Context". Speech to the Australia New Zealand Leadership Forum, 29-30 April 2005.

Pre-Forum planning correspondence between Frank Holmes and Simon Murdoch and Kerry McDonald. 3 November 2003. 